\title{
“ANÁLISIS MULTITEMPORAL MEDIANTE IMÁGENES DE SENSORES REMOTOS PARA LA DETERMINACIÓN DE LOS CAMBIOS DE USO DE SUELO EN EL MUNICIPIO DE SAN FRANCISCO DE SALES, CUNDINAMARCA (COLOMBIA) ENTRE LOS AÑOS 90'S Y 2018"
}

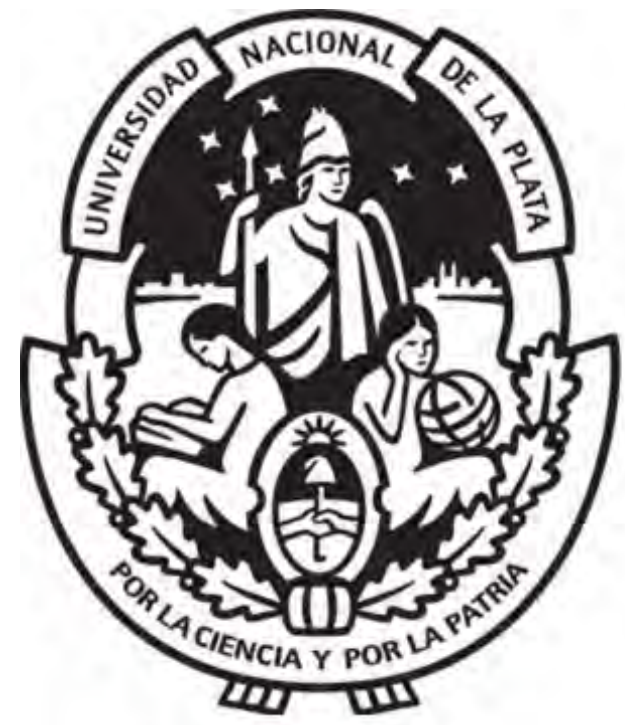

Tesis de Maestría presentada por:

ING. YULY MARCELA NIÑO MARTÍNEZ

Ante la facultad de Ingeniería y la Facultad de Ciencias Astronómicas y Geofísicas de la Universidad Nacional de La Plata para optar al Grado Académico de:

\section{MAGISTER EN GEOMÁTICA}

Director de Tesis: Dr. Jorge Sisti

Jurado de Tesis: Dra. Fernanda Gáspar

Dra. Alejandra Geraldi

Dra. Sandra Torrusio

Lugar y fecha de presentación oral y pública: La Plata, 10 de Diciembre de 2020 
"Únicamente la autora es responsable de las ideas expuestas en el presente trabajo"

Copyright @ 2020 por Yuly Marcela Niño Martínez

Todos los derechos reservados. 


\section{DEDICATORIA}

A mi madre, por su esfuerzo y esmero al brindarme las herramientas educativas que me han permitido llegar hasta aquí, por sembrar en mí la semilla de la superación, alentarme a volar y confiar en mis habilidades.

A la fuente de inspiración y el mejor regalo de la vida, mis sobrinos Duván, Fernanda, Leonardo y Esteban, que este sea un estímulo más para atreverse a cumplir todas sus aspiraciones. Que sus sueños sean más grandes que sus miedos, a volar mis retoños, a volar... 


\section{AGRADECIMIENTO}

A mi familia principal motivación en mi vida, por su comprensión, apoyo y aliento constante, pero ante todo por su incondicionalidad a lo largo de mi recorrido. Sin ellos nada tendría sentido. "Para ellos es este logro académico y personal".

A mí querido amigo y colega Ing. William Fagua, por retornarme al camino cada vez que me disipaba, por el soplo de esperanza cada vez que desistía y su ayuda en este prolongado proceso de la maestría. Este título académico es nuestro.

A mi director de tesis: Dr. Jorge Sisti, quien me brindó su valiosa orientación y fue mi asesor en la elaboración de esta tesis de grado.

A todos mis amigos y conocidos más cercanos que directa o indirectamente me animaron en la realización de este trabajo. 


\section{RECONOCIMIENTO}

A la Universidad Nacional de La Plata, por brindarme la oportunidad de desarrollar capacidades, competencias y optar el grado académico de Maestra en Geomática. 


\section{RESUMEN}

El presente trabajo consistió en el análisis multitemporal de las coberturas y usos del suelo del municipio de San Francisco de Sales, ubicado al noroccidente del departamento de Cundinamarca en Colombia. Con el uso de imágenes de satélite Landsat 4 TM y Sentinel-2 MSI de los años 1988 y 2018 respectivamente. Se identificaron los cambios en las coberturas terrestres entre estas dos épocas a escala 1:100.000, mediante el uso de la clasificación supervisada y con base en la metodología Corine Land Cover adaptada para Colombia (CLC), a su vez, se hizo la validación de los resultados obtenidos con el cálculo de la matriz de error o de confusión, la cual compara los resultados de la clasificación frente a áreas verdad terreno y brinda el grado de certeza que se tiene respecto a la clasificación supervisada.

Los resultados obtenidos, reflejan primordialmente cambios en los territorios artificializados, apareciendo consigo dos nuevas coberturas correspondientes a tejido urbano discontinuo y zonas industriales, adicionalmente se evidencia una dramática disminución en las áreas agrícolas y la aparición de un nuevo fenómeno llamado finca raíz en su lugar. Los hallazgos encontrados sirven como referente en el marco del Esquema de ordenamiento territorial para el municipio en cuestión.

Palabras Clave: Análisis multitemporal, usos del suelo, Imágenes de satélite, Corine Land Cover, Matriz de confusión, clasificación supervisada. 


\begin{abstract}
This work consisted of multi-temporal analysis of coverages and soil uses of the municipality of San Francisco de Sales, located to the northwest of the department of Cundinamarca in Colombia. With the use of Landsat 4 TM and Sentinel-2 MSI satellite images 1988 and 2018 respectively, the changes identified in the land cover between these two periods at 1: 100.000 scale, using supervised classification and based on the Corine Land Cover methodology adapted for Colombia ( CLC), in turn, the validation of the results obtained by calculating the error or confusion matrix, which compares the results of the classification against the truth land areas and provides the certainty that it has over the supervised classification.

The results primarily reflect changes in the artificialized territories, appearing with it two new coverages corresponding discontinuous urban fabric and industrial áreas, additionally a dramatic decrease in agricultural areas and the appearance of a new phenomenon called real estate instead. The findings serve as a benchmark in the framework of territorial planning for the municipality.
\end{abstract}

Keywords: Multitemporal analysis, soil uses, satellite images, Corine Land Cover, confusion matrix, supervised classification. 


\section{TABLA DE CONTENIDO}

GLOSARIO DE TÉRMINOS

1. INTRODUCCIÓN 18

1.2 Problemática y Justificación 19

$\begin{array}{ll}1.2 \text { Objetivos } & 21\end{array}$

2. MARCO TEÓRICO 22

2.1 Percepción Remota 22

2.2 Estudios Multitemporales 25

2.3 Matriz de Transición 27

2.4 Uso de Suelo 28

2.5 Coberturas de la tierra 28

2.6 Metodología Corine Land Cover 28

$\begin{array}{lll}2.7 & \text { Programa LANDSAT } & 29\end{array}$

2.7.1 Thematic Mapper TM 31

2.8 Sentinel 31

2.8.1 Multispectral Instrument 32

2.8.2 Nivel de Procesamiento 32

2.8.2.1 Reflectancia en el Techo de la Atmósfera (TOA) 33

2.8.2.2 Corrección Dos 33

3. LOCALIZACIÓN DEL ÁREA DE ESTUDIO 34

4. METODOLOGÍA 36

4.1 Recopilación de la Información 38

4.2 Pre-procesamiento de las Imágenes de Satélite 43

4.2.1 Corrección Radiométrica y Atmosférica 44

4.2.2 Fragmentación del área de estudio 46

4.2.3 Definición de la Escala de trabajo 47 
4.2.4 Combinación de Bandas 47

4.3 Procesamiento de la Información 51

4.4 Validación de los resultados 60

4.4.1 Validación clasificación 1988 Landsat 4TM 60

4.4.2 Validación clasificación 2018 Sentinel-2 MSI 64

4.5 Generación de Información - Generalización 68

4.6 Uso de la Información $\quad 71$

5. RESULTADOS 76

5.1 Territorios Artificializados 78

$\begin{array}{lll}5.2 & \text { Territorios Agrícolas } & 79\end{array}$

5.3 Bosques y Áreas Seminaturales 82

5.4 Conflicto de uso del suelo 83

6. CONCLUSIONES $\quad 87$

7. BIBLIOGRAFÍA 90

$\begin{array}{ll}\text { 8. ANEXOS } & 99\end{array}$ 


\section{ÍNDICE DE TABLAS}

Tabla 1 Características LANDSAT 4- TM Thematic Mapper ................................ 30

Tabla 2 Características SENTINEL 2- MSI MultiSpectral Instrument .................... 31

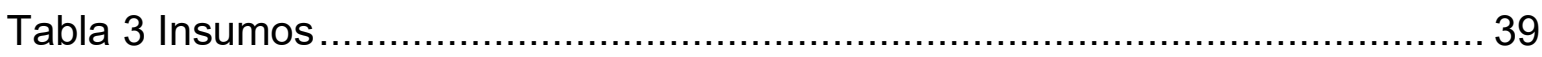

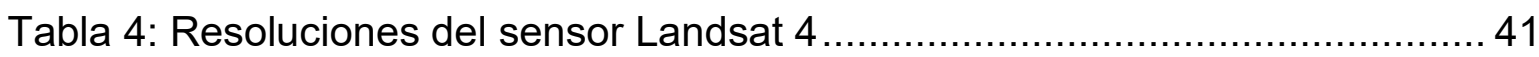

Tabla 5: Resoluciones del sensor Sentinel-2 …........................................... 41

Tabla 6: Registro de Parámetros Geodésicos .................................................. 42

Tabla 7: Combinaciones de bandas utilizadas para Landsat y Sentinel-2MSI

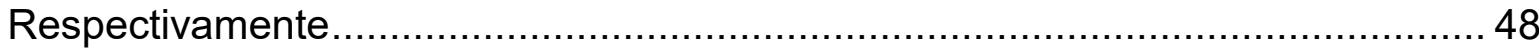

Tabla 8: Niveles CLC identificados en el municipio de San Francisco ................... 52

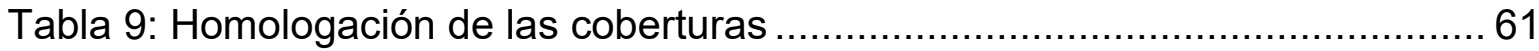

Tabla 10: Validación de la Clasificación ........................................................... 62

Tabla 11: Cobertura de la tierra CLC identificadas en el municipio de San Francisco

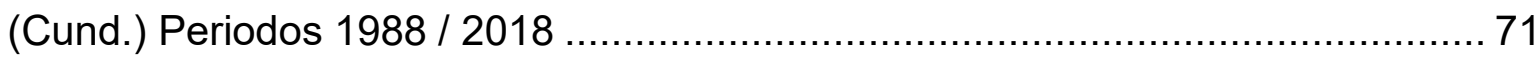

Tabla 12: Planteamiento de la Matriz de Tabulación Cruzada ............................... 73

Tabla 13: Resultado de la Matriz de Tabulación Cruzada (Áreas en ha) .............. 75

\section{ÍNDICE DE ILUSTRACIONES}

Ilustración 1: Matriz de transición para dos mapas de diferente fecha .................. 27

Ilustración 2: Cronología del Programa LANDSAT .............................................. 29

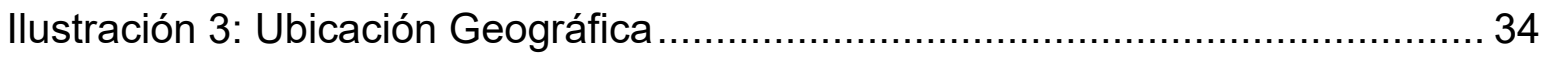

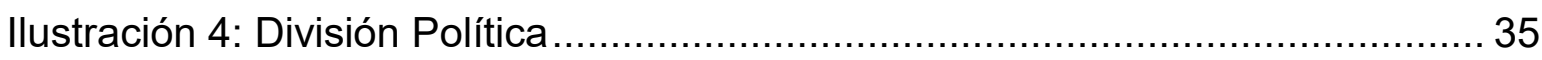

Ilustración 5: Resumen Metodológico …………............................................ 37

Ilustración 6: Escena de imágenes descargadas ……….................................. 39

Ilustración 7: Geodatabase con los insumos y resultados del estudio Multitemporal 
llustración 8: Metadato de la imagen. 44

Ilustración 9: Configuración de las correcciones utilizadas en QGis para Landsat 4.

Ilustración 10: Configuración de las correcciones utilizadas en QGis para Sentinel $2 \mathrm{MSI}$ 46

Ilustración 11: Fragmentación del área de clasificación ........................................4 47

Ilustración 12: Imagen Sentinel-2 en Falso Color RGB 8, 4, 3.......................... 49

Ilustración 13: Imagen en Falso Color RGB 8, 11, 4 Sentinel-2.......................... 50

Ilustración 14: Centro poblado San Francisco ................................................. 52

Ilustración 15: Quintas de recreo vereda Toriba................................................ 52

Ilustración 16: Inmunizadora de maderas San Francisco ...................................... 53

Ilustración 17: Cantera de Triturados Cerro Cuadrado........................................54

Ilustración 18: Paisaje pastos limpios Alto del vino ..............................................54

Ilustración 19: Mosaico de Cultivos (Plátano, café, cítricos) …….......................... 55

Ilustración 20: Mosaico de cultivos y espacios naturales vereda San Miguel ........55

llustración 21: Mosaico de cultivos, pastos y espacios naturales vereda San Miguel.

Ilustración 22: Bosque natural denso cercanías de La Laja ................................56

Ilustración 23: Parque Ecológico Jericó ......................................................... 57

Ilustración 24: Bosque ripario quebrada El Muña ...............................................57

Ilustración 25: Plantación Forestal de Eucalyptus .................................................58

llustración 26: Firmas Espectrales de la Clasificación Supervisada en imagen

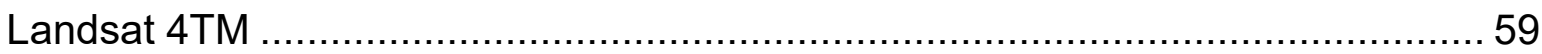

Ilustración 27: Resultado Validación de clasificación 1988 .................................. 62

Ilustración 28: Áreas no comparables por presencia de nubes .............................. 63

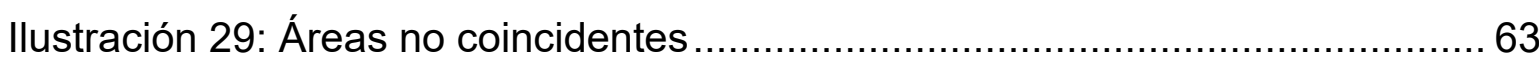


Ilustración 30: Puntos de Muestreo Verdad Terreno 65

Ilustración 31: Almacenamiento de Información Puntos de Muestreo ..................... 66

Ilustración 32: Matriz de Confusión o de error.

67

Ilustración 33: Agregación de un polígono pequeño ubicado dentro de un polígono grande - 112 (<5 ha) y 211 ( $\geq 25 \mathrm{ha})$ 69

Ilustración 34 Generalización para centros poblados. 69

Ilustración 35: Delimitación de bosque fragmentado en zona de bosque denso... 70

Ilustración 36: Delimitación zona de mosaico en zona de bosque denso. 70

Ilustración 37: Delimitación de espacios naturales menores a 25 ha (311), ubicado dentro de un polígono de cultivos ( $211 \geq 25 \mathrm{ha}$ ). 70

Ilustración 38: Mapa de Cambios y Persistencias en el periodo 1988-2018 ......... 73 Ilustración 39: Mapa de cobertura del suelo San Francisco de Sales 76 Ilustración 40: Cobertura de la tierra CLC identificadas en el municipio de San Francisco (Cund.) para el periodo 1988 -2018 ……...................................... 77

Ilustración 41: Territorios Artificializados ...................................................... 78

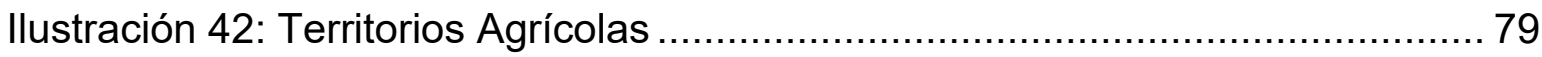

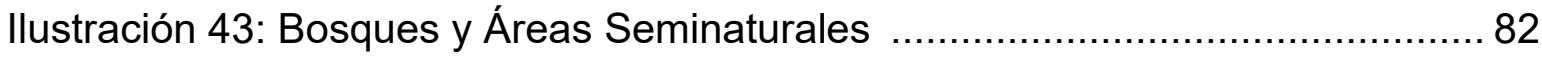

Ilustración 44: Mapa de cobertura del suelo 2018 y Mapa de uso propuesto del suelo 1999. 84

llustración 45: Mapa conflicto de uso 85

\section{ANEXOS}

Anexo 1: Mapa de Cobertura del Suelo 1988.................................................. 100

Anexo 2: Mapa de Cobertura del Suelo 2018.............................................. 101

Anexo 3: Mapa de Cobertura y Usos Propuestos del Suelo ............................... 102

Anexo 4: Mapa Conflicto de Uso del Suelo …………................................... 103

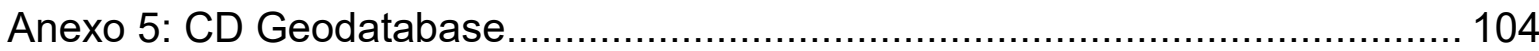




\section{GLOSARIO DE TÉRMINOS}

Análisis Multitemporal: Es el proceso mediante el cual se hace la comparación de las coberturas interpretadas en dos imágenes de satélite y/o mapas de un mismo lugar en diferentes fechas. Lo anterior permite identificar los cambios respecto de las coberturas que han sido clasificadas. Este proceso involucra varias actividades dentro de las cuales se encuentran: la adquisición de los insumos (Imágenes, mapas), la preparación, la clasificación de las coberturas presentes y finalmente la determinación de cambios en las mismas. Adicionalmente es necesario el trabajo de campo para constatar y/o dar confiabilidad a la clasificación o como indicador de la precisión en los resultados.

Banda: Intervalo de longitud de onda dentro del espectro electromagnético. Se denomina banda a cada uno de los canales de adquisición de datos de un sistema sensor.

Contraste: Diferencia de densidad entre las partes más claras y oscuras de una imagen.

CORINE Land Cover Colombia, CLC: Permite describir, caracterizar, clasificar y comparar las coberturas de la tierra, interpretadas a partir de imágenes de satélite de resolución media (Landsat), para la construcción de mapas de cobertura vegetal y uso del suelo.

Corporación Autónoma Regional del Río Grande de la Magdalena, CORMAGDALENA: Tiene como objeto la recuperación de la navegación y de la actividad portuaria, la adecuación y conservación de tierras, la generación y distribución de energía, así como el aprovechamiento sostenible y la preservación del medio ambiente, los recursos ictiológicos y demás recursos naturales renovables.

Datum: Superficie en la cual se referencian todas las coordenadas $(x, y, z)$, tiene asociado un elipsoide específico y uno o más puntos materializados sobre la superficie terrestre. 
Espectro electromagnético: Distribución energética, medida en función de la frecuencia, del conjunto de las ondas electromagnéticas que van desde los rayos gamma y rayos $X$ hasta las ondas de radio, pasando por el espectro térmico responsable del calor que percibimos y que no son directamente perceptibles por el ser humano. Estas formas energéticas pueden reflejarse en la superficie terrestre y ser capturadas por el sensor del satélite proporcionando información sobre sus características, tal y como lo hacen las ondas del espectro visible. La energía se mide en micrómetros.

Formato Ráster: Se caracteriza por la existencia de una red formada por celdas o cuadrículas, son mayormente conocidas como píxel y representan una cualidad o propiedad especial (color, altitud, etc.)

Formato TIFF (Tagged Image File Format): Formato de fichero para gráficos de mapas de puntos. Almacena las imágenes mediante la descripción de información en bloques o marcas. Cada marca describe un atributo de la imagen o un desplazamiento desde el principio del fichero hasta una cadena de píxeles.

Formato Vectorial: Representación espacial de los elementos geográficos a partir de tres estructuras básicas: puntos, líneas y polígonos.

Georreferenciación: Proceso mediante el cual se asigna coordenadas con una proyección y Datum específicos a un objeto o superficie en el plano en un archivo ráster (imagen) o vectorial (líneas).

Histograma: Representación gráfica y estadística que ofrece información valiosa sobre una imagen digital, indica el número de veces que aparece cada Nivel Digital en la imagen en forma de gráfico, permite leer e interpretar los cambios que se efectúan a la imagen. Cualquier incremento o disminución del brillo y/o contraste, tonalidad o color, tamaño, etc., implica una transformación en el histograma.

Instituto de Hidrología, Meteorología y Estudios Ambientales, IDEAM: Es una entidad del gobierno de Colombia dependiente del Ministerio de Ambiente y Desarrollo Sostenible. Se encarga del manejo de la información científica, hidrológica, meteorológica y todo lo relacionado con el medio ambiente. 
Instituto Geográfico Agustín Codazzi, IGAC: Es la entidad encargada de producir el mapa oficial y la cartografía básica de Colombia; elaborar el catastro nacional de la propiedad inmueble; realizar el inventario de las características de los suelos; adelantar investigaciones geográficas como apoyo al desarrollo territorial; capacitar y formar profesionales en tecnologías de información geográfica y coordinar la Infraestructura Colombiana de Datos Espaciales.

Imagen multiespectral: Producto espacialmente explicito generado por un sensor remoto mediante la combinación de imágenes que se registran en diferentes longitudes de onda o bandas espectrales.

Imagen Satelital: Es la representación visual de la información captada por un satélite artificial. Estos satélites disponen de sensores que les permiten recolectar información que refleja la superficie terrestre. Una vez que reciben los datos, los envían de nuevo a la tierra donde son procesados.

Layer stack: Es el apilamiento o unión de bandas de una imagen de satélite, de tal manera que estén agrupadas en un mismo archivo.

MAGNA - SIRGAS: Marco Geocéntrico Nacional de Referencia, densificación del Sistema de Referencia Geocéntrico para las Américas. Sistema de referencia oficial para Colombia. Garantiza la compatibilidad de las coordenadas colombianas con las técnicas espaciales de posicionamiento, por ejemplo, los sistemas GNSS (Global Navigation Satellite Systems), y con conjuntos internacionales de datos georreferenciados.

Metadatos: Describen el contenido, calidad, condición, formato, fechas de referencia y en el caso de los datos geográficos, además, información sobre aspectos como cobertura espacial, sistemas de coordenadas y de referencia geodésica, entre otros.

Nivel Digital (ND): Valor numérico discreto asignado por el sistema formador de imágenes a cada celda en respuesta a la irradiancia recibida sobre el plano focal del sensor.

Pansharpened: Producto multiespectral obtenido de la fusión de imágenes multiespectrales (georreferenciadas y orto-rectificadas) con imágenes 
pancromáticas capturadas por el mismo sensor cuyo resultado es una imagen de mayor resolución espacial. Corresponde a un tipo de sinergismo.

Píxel (Picture Element): Unidad básica de información gráfica que se refiere a cada uno de los puntos indivisibles que conforman una imagen, es decir, la mínima área de captura en el formato Ráster. A mayor densidad de píxeles, mayor calidad de imagen.

Proyección cartográfica: Sistema ordenado que transforma la superficie curva de la tierra en un plano. Se representa gráficamente en forma de malla.

Radiancia: Flujo de energía (irradiante o incidente) que mide el sensor y depende en cierta medida de la reflectancia.

Resolución: Capacidad de un sistema sensor para distinguir información de detalle en un objeto. En teledetección se habla de distintos tipos de resolución: espacial, espectral, radiométrica y temporal.

Resolución Espacial: Es el tamaño del píxel, en algunos casos se emplea el concepto de IFOV (campo instantáneo de visión) que se define como la sección angular (en radianes) observada en un momento determinado, ya que el tamaño del píxel en una escena es variable incrementándose conforme la distancia aumenta al punto nadir.

Resolución espectral: Longitudes de onda en las cuales un sensor es capaz de adquirir información. La fotografía puede ofrecer películas pancromáticas, infrarrojo blanco negro, color natural o infrarrojo color.

Resolución radiométrica: Cantidad de energía que se puede medir en una escala radiométrica en el sensor. En el caso de los sistemas fotográficos, la resolución radiométrica del sensor se indica por el número de niveles de gris recogido por el mismo. Para evaluar la calidad radiométrica se evalúa un parámetro denominado "bit number".

Resolución Temporal: Es el periodo de tiempo en el que un sensor adquiere las imágenes de un área determinada de la superficie terrestre. Está en función de las características orbitales y de diseño de la plataforma. Se destacan dos aspectos como son el Ciclo de Recubrimiento y el Periodo Orbital, el primero corresponde al 
tiempo empleado en recorrer la misma área de la tierra y el último aspecto se refiere al tiempo utilizado para dar una órbita sobre el planeta.

RGB: Sigla en inglés de rojo-verde-azul. Se trata de un sistema de especificación del color basado en la propiedad aditiva de los tonos primarios que es el comúnmente utilizado en los sistemas informáticos y en la composición en verdadero o en falso color de las imágenes espaciales.

Vecino más cercano (Nearest Neighbor): Técnica de remuestreo que toma los datos del píxel o vecino más cercano para asignar el valor del píxel de salida. 


\section{INTRODUCCIÓN}

La teledetección espacial ofrece una amplia alternativa que proporciona información de toda la superficie del planeta y con mayor frecuencia de actualización, hoy día está más fácilmente al alcance de cualquier usuario gracias a las plataformas tecnológicas. Existen gran variedad de estudios alrededor de las imágenes de satélite, pues se ha encontrado gran utilidad en ellas. En la actualidad se ha identificado el auge de estas para estudios de multitemporalidad, especialmente en el cambio de usos del suelo y expansión urbana, dado que, el hombre ocupa y transforma de distintas maneras el espacio geográfico que lo rodea y con el pasar del tiempo puede generar dificultades para sí mismo y/o sus generaciones. Por lo anterior, surge la preocupación y necesidad de estudiar la dinámica y los impactos que sus modos de expansión y crecimiento producen en el medio.

Uno de los impactos más significativos a nivel global, son los cambios de uso y coberturas del suelo, entender estos procesos de transformación del paisaje requieren de describir qué coberturas han cambiado, cuándo y dónde han ocurrido los cambios. Con base en esta información se pueden identificar las áreas más propensas a variar y así generar los ajustes necesarios a los planes de ordenamiento territorial municipal e intervenir de una manera focalizada en el aprovechamiento de las tierras más acorde a la normatividad, en pro del medio ambiente y la sociedad.

En Colombia desde 1997, con la promulgación de la ley 388, los planes de ordenamiento territorial (POT) se han venido constituyendo en los principales instrumentos reguladores de los usos del suelo a nivel municipal. Esta ley establece "[...] el conjunto de principios, instrumentos y disposiciones sobre planeación y gestión territorial con el fin de lograr un ordenamiento físico que promueva el desarrollo socioeconómico en armonía con la naturaleza [...]" (Hernández Gómez et ál, 2013, p. 258), y, por tanto, incorpora de manera definitiva tanto la dimensión ambiental como la territorial en la planeación del país. No obstante, aún existen discordancias entre la aplicación de la ley y la disposición del territorio.

El presente estudio de análisis multitemporal se llevó a cabo usando imágenes satelitales del área de trabajo, con el fin de conocer las variaciones en el uso del 
suelo que se ha experimentado en los últimos 30 años y la construcción de productos temáticos locales detallados, en donde se plasman los resultados obtenidos. Esto servirá como base para la realización de proyectos que forjen un desarrollo sostenible de la región.

\subsection{Problemática y Justificación}

El Departamento de Cundinamarca debido a su ubicación geográfica presenta variedad de clima, zonas de cultivo, animales consumibles, vías de acceso a las poblaciones, infraestructura física, una gran dinámica de la industria y sectores agrícolas altamente tecnificados, que permiten a la región un privilegio en el contexto económico nacional (Castro M, 2010). Su división administrativa está compuesta por 116 Municipios agrupados a su vez en 15 provincias las cuales son: Almeidas, Alto Magdalena, Bajo Magdalena, Gualivá, Guavio, Magdalena Centro, Medina, oriente, Rionegro, Sabana Centro, Sabana occidente, Soacha, Sumapaz, Tequendama y Ubaté. Bogotá D.C. es oficialmente su capital.

San Francisco de Sales es uno de los 116 municipios pertenecientes al departamento de Cundinamarca, es el territorio de clima templado $\left(20^{\circ} \mathrm{C}\right)$ más cercano a la capital. Históricamente su economía ha girado en torno a la agricultura, siendo esta mayormente de cultivos de café, cítricos y plátano. En las últimas tres décadas, ha ocurrido un fenómeno muy interesante de cambio en la distribución del territorio, debido a una serie de eventos políticos, económicos y sociales que han transformado en gran parte el uso del suelo Sanfrancisqueño ${ }^{1}$, por tal razón y en busca del beneficio de sus habitantes, hubo una transición conjunta a la ganadería y en pequeña escala a la explotación de canteras. Sus suelos, han sido sometidos reiteradamente a intensas actividades agropecuarias trayendo como consecuencia degradación y contaminación. Adicionalmente, han sido cubiertos

\footnotetext{
${ }^{1}$ Durante la década de los noventa la competitividad de la caficultura colombiana estuvo comprometida por el proceso de envejecimiento de sus cultivos. Dicho proceso puede explicarse por la caída en las cotizaciones internacionales del café como efecto del rompimiento del pacto internacional de cuotas en 1989 y la llegada de la plaga más importante que afecta el café, la Broca (Hypothenemus Hampei). Situación que se trasladó a las familias cafeteras a través de una disminución de los ingresos promedio derivados de la actividad. (Guarín Nuñez, 2010).
} 
desordenadamente como secuela de la expansión poblacional y el desplazamiento forzado al que ha sido sometido el departamento de Cundinamarca y que incrementó a comienzos de los años noventa, gracias a su importante actividad económica y su cercanía con Bogotá D.C. (Fondo de Inversión para la Paz, 2001). Como consecuencia de los sucesos anteriores y sumado a la falta de apoyo gubernamental, la creciente demanda de bienes y servicios, el desconocimiento de las funciones e importancia del suelo y de alternativas para su recuperación, la falta de procesos de planeación y de ordenamiento del territorio que no tuvieron en cuenta las características de los usos de este para su correcto aprovechamiento, la desarticulación institucional y la carencia de normas e instrumentos para la gestión sostenible del suelo, han hecho que se presente una grave degradación de los suelos, que empeora con el pasar de los años.

El uso del suelo es un factor fundamental en el sustento de la sociedad y el ser humano, dado que es el elemento principal de las estructuras ecológicas y los ecosistemas. El manejo adecuado de este es de vital importancia para el éxito de las políticas ambientales y territoriales. Es aquí, donde el análisis multitemporal entra a jugar un rol importante, dado que, por medio de este se permite detectar cambios entre diferentes fechas de referencia, pudiendo deducir la evolución del medio natural o las repercusiones de la acción humana sobre este (Chuvieco E. , 1995). Sumado a lo anterior, el complementar con el uso de una base de datos geográfica integrada y la incorporación e integración de la matriz de transición formulada por Pontius et ál. (2004), permiten identificar y analizar, en forma espaciotemporal, las modificaciones y cambios ocurridos dentro de un periodo determinado para el área de estudio. Es así, como en este trabajo se usarán herramientas y técnicas de teledetección y SIG que son de valiosa ayuda para obtener una valoración del territorio y poder llevar a cabo acciones de recuperación, mitigación y/o corrección en este. 


\subsection{Objetivos}

El objetivo principal de este trabajo es identificar la distribución espacial y analizar la dinámica de cambio del uso del suelo mediante un análisis multitemporal en el municipio de San Francisco de Sales, Cundinamarca, que permita mostrar los diferentes fenómenos que han afectado esta región en las últimas tres décadas.

Los objetivos específicos que permitirán alcanzar el objetivo principal son:

- Aplicar clasificaciones supervisadas para identificar los tipos de cobertura presentes en el área de estudio, de acuerdo con la metodología Corine Land Cover adaptada para Colombia.

- Definir la Matriz de transición para puntualizar qué usos presentan pérdida, ganancia o permanecen en este periodo de tiempo.

- Construir una base de datos geográfica a partir de la información consultada y obtenida para este estudio. 


\section{MARCO TEÓRICO}

\subsection{Percepción Remota}

Teniendo en cuenta las diferentes definiciones encontradas en la literatura, se resalta la certeza que aporta González y Dalannais (1976) al denotarla claramente como una de las actividades más antiguas del hombre: "reconocer a distancia". Ahora, en una aproximación más puntual Lillesand \& Kiefer (1994, p. 1) señalan la percepción remota como la ciencia y arte de obtener información de un objeto sin que exista contacto directo entre él y el sensor. Ya en este punto, se ha observado cómo se emplean términos como sensor remoto, teledetección o como se ha expresado recurrentemente percepción remota de forma similar y si quiere como sinónimos, tal como lo expresan Velasco et ál. (2015), para definirlas como el uso de tecnologías de sensores aéreos en la detección de objetos sobre la tierra bien sea a nivel terrestre, oceánico o atmosférico mediante el análisis de señales de la radiación electromagnética propagada. Richards y Jia (2006), añaden que esta técnica permite adquirir información espacial, temporal y espectral de una entidad sin tener contacto físico con ella. Agrupando lo mencionado con anterioridad, Chuvieco (1990, p. 27) señala:

Si hemos definido la teledetección espacial como aquella técnica que permite adquirir imágenes de la superficie terrestre desde sensores instalados en plataformas espaciales, estamos suponiendo que entre la Tierra y el sensor existe una interacción energética, ya sea por reflexión de la energía solar o de un haz energético artificial, ya sea por emisión propia.

El origen de la percepción remota, como precisa González y Dalannais (1976) se remonta al hombre primitivo ante la necesidad de alimentarse y sobrevivir a los peligros que el entorno le ofrecía y que ante su limitada capacidad sensorial se vio obligado a crear instrumentos o sensores para ampliarla y cuya finalidad es complementar su capacidad de percepción. Dichos sensores han tenido una evolución importante enmarcada en dos técnicas: la fotografía y la navegación aérea en globos. Complementando estos hechos Velasco et ál. (2015), resumen que el sensor remoto moderno tiene su inicio en el siglo XX con la fotografía aérea y que su nacimiento en el espacio se dio hacia 1957 con el lanzamiento del satélite 
Sputnik, finalmente para el año 1969 tuvo lugar la primera experiencia de fotografía orbital multiespectral aplicado al estudio de recursos del planeta. Adicionalmente también se señalan los 3 hechos más importantes en la evolución de la percepción remota como lo son: aparición de la fotografía y el desarrollo posterior de sensores con la capacidad de captar y procesar radiación electromagnética; el paso de imágenes analógicas a digitales; y el avance en telecomunicaciones. En estos aspectos, autores como Arredondo y Rodriguez (2005), coinciden y además resaltan que posterior al lanzamiento de la misión del Sputnik se dio comienzo a una serie de misiones para la exploración del planeta, se destacan los satélites de la serie TYROS y APOLO que hacia los años 70 y fruto de varias experiencias se dio el lanzamiento de la serie ERTS, comúnmente reconocido como LANDSAT. Después de esto, vinieron nuevas misiones gracias a los aceptables resultados, entre los programas más conocidos se pueden mencionar a los satélites correspondientes de SPOT, MOS1 y MODIS, y específicamente para el caso de estudio se tiene la serie de satélites del sistema Sentinel.

Finalmente, y haciendo un paralelo frente a las anteriores misiones, es importante destacar los avances que a la fecha se han dado tanto a nivel tecnológico como a nivel de adquisición de la información. De acuerdo con esto, GeoSpatial (2013) divide las imágenes adquiridas por los satélites en dos grupos: ópticas y de radar y al mismo tiempo las clasifica según su resolución espacial como alta (pixel inferior a 1 metro) y media (pixel mayor a 1 metro). De este modo, dentro de las imágenes ópticas de alta resolución se pueden mencionar los productos obtenidos de la familia de satélites WorldView (1, 2 y 3), QuickBird, GeoEye-1, IKONOS, TripleSat, KOMPSAT (2 y 3), EROS (A y B), DEIMOS 2, GF-2, Superview-1, JILIN y GAOFEN (6 y 7). De los satélites anteriores se resalta: la resolución espacial alcanzada de 0.3 m en pancromático del WorldView 3 el cual se lanzó en 2014; la capacidad de EROS B para colectar imágenes en la noche; la resolución espacial de $0.5 \mathrm{~m}$ del SuperView-1 sin necesidad de re muestrear los datos; el DEIMOS 2 que se lanzó en 2014 fue el segundo satélite español que se envió al espacio; el JILIN finaliza su periodo de funcionamiento en 2020; el lanzamiento del GAOFEN-7 se hizo en 2019. Continuando con la clasificación dada por GeoSat, se tienen las imágenes ópticas de media resolución, en donde, se encuentran los satélites de la constelación ALOS 
(PRISM y AVNIR-2 finalizaron su misión en 2011), TH (1 y 2; siendo el 1 el primer satélite español enviado al espacio en 2009) y DEIMOS-1.

Respecto de las imágenes de radar en alta resolución, se encuentran los satélites GAOFEN-3, primer satélite civil de imágenes polarimétricas SAR; Kompsat-5 el primer satélite de radar lanzado por Corea en 2013 y Capella lanzado en agosto de 2020, el cual sobresale por ser la última generación de microsatélites en banda X y por su naturaleza permite la adquisición de imágenes sin importar el clima ni la hora del día. En resolución media se destaca ALOS con su sensor PALSAR.

En cuanto a la disponibilidad de las imágenes, cabe recordar que, estas se encuentran en un entorno comercial, en donde, los productos se entregan con un determinado nivel de procesamiento que puede ser básico, estándar y ortorectificado, como es el caso de las imágenes ópticas. En cambio, con las de radar se pueden encontrar productos básicos, georreferenciados y con correcciones radiométricas.

Por otro lado, en el contexto de las misiones actuales, es importante resaltar un proyecto denominado SAOCOM $1 \mathrm{~A}$ y $1 \mathrm{~B}$, el cual fue desarrollado por la Comisión Nacional de Actividades Espaciales (CONAE) en conjunto con la Agencia Espacial Italiana (ASI). Los satélites SAOCOM junto a la constelación Italiana COSMOSkyMed integraran el sistema Ítalo Argentino de satélites para la Gestión de Emergencias (SIASGE). SAOCOM es el satélite SAR en banda $L$ con mayor desempeño que existe hasta la fecha. Su resolución espacial es de 10 a 100 metros, la constelación presenta una revisita de 8 días y se diseñó principalmente para generar mapas de humedad del suelo (INVAP, 2018). Según Esperbent y Migliorati (2018), SAOCOM 1A está en órbita desde 2018 y SAOCOM 1B se lanzó recientemente en agosto de 2020, esta constelación de satélites cuenta con la capacidad de brindar información que servirá para prevenir, monitorear, mitigar y evaluar catástrofes naturales; además, de los ya conocidos aportes sobre la humedad del suelo y su disponibilidad e índices de vegetación, se suma la aplicación en alertas de inundaciones, incendios y enfermedades en el ámbito agrícola. Cabe mencionar que, Argentina ya había lanzado otros satélites de índole académica (SAC-B en 1996, SAC-A en 1998, SAC-C en 2000 y SAC-D en 2011) y 
de comunicación (ARSAT-1 y 2 en 2015); siendo así SAOCOM el primero para la observación ambiental y de mayor desarrollo tecnológico hasta la fecha.

Concluyendo, se tienen gran variedad de opciones para la adquisición de información mediante la percepción remota, su evolución ha venido de la mano con los desarrollos que se dan en todas las ciencias que le aportan, de esta manera, así como crece la oferta de productos derivados de las imágenes, también se crean nuevas herramientas para acceder y almacenar la información. Tanto empresas como los mismos operadores de los satélites, han diseñado a través de la web diferentes recursos como visores, aplicativos, catálogos, etc., para hacer más fácil el acceso a sus productos, incluso es posible solicitar imágenes de sitios específicos mediante un servicio denominado programación de la escena. Actualmente las imágenes tienen más frecuencia, son más oportunas y su calidad aumenta, es decir, la oferta aumentó y también las facilidades para acceder a las imágenes. Así mismo, aparece un conflicto con respecto al almacenamiento y tratamiento de las mismas; en cuanto al primer aspecto, se cuenta con ordenadores y dispositivos con amplia capacidad y adicionalmente se puede almacenar la información en servidores a través de internet, lo que es conocido comúnmente como almacenamiento en la nube. De otro lado, para resolver el tratamiento de las imágenes, como se mencionó antes, los productos se entregan con niveles de procesamiento de acuerdo a las necesidades de los usuarios.

\subsection{Estudios Multitemporales}

De acuerdo con Riaño (2002) el estudio de los cambios que se producen en la superficie terrestre es uno de los aportes más importantes de la percepción remota que permite hacer el seguimiento de este tipo de procesos dinámicos. Dicho aporte, según Blasi et ál. (2003), se conoce como análisis o estudio multitemporal, el cual permite interpretar las dinámicas de un territorio, mediante la comparación de información de diferentes épocas con el propósito de determinar la localización y tipo de cambio en el tiempo. Para Di Somma y Smiraglia (2009), este tipo de análisis es considerado como un método eficaz para obtener una visión orgánica y completa del proceso evolutivo de un territorio. Según Riaño (2002) la detección de cambios o el análisis multitemporal radica en determinar las diferencias en el estado de un 
fenómeno mediante información adquirida en diferentes épocas. Chuvieco (1990), define los estudios Multitemporales como análisis espaciales elaborados a partir de la comparación de coberturas interpretadas en imágenes de satélite de un mismo lugar para distintos periodos con el fin de evaluar los cambios en las mencionadas coberturas.

Riaño (2002) resalta como condición fundamental que el sensor proporcione cobertura periódica, en las mismas bandas espectrales y bajo condiciones similares (altura, hora, ángulo de adquisición) para la elaboración de estudios multitemporales con percepción remota. Adicionalmente menciona las etapas para realizar un estudio de detección de cambios a partir del uso de imágenes de satélite: definición del área de estudio y leyenda temática a emplear de acuerdo con la superficie de interés, posteriormente señala las consideraciones relevantes en cuanto al sistema de percepción remota o sensor (resolución temporal, espacial, espectral y radiométrica) y las relacionadas con el ambiente (condición atmosférica, condiciones de la superficie terrestre y ciclos fenológicos). Respecto al procesamiento de las imágenes para extraer información de los cambios, destaca la adquisición adecuada de datos, pre procesamiento de las imágenes satelitales (corrección geométrica y homogenización radiométrica), la selección del algoritmo para la detección de cambios, clasificación digital de la imagen, empleo de software de procesamiento espacial para la detección de cambios, generación de productos asociados y por último la presentación de resultados.

En cuanto a las técnicas de análisis multitemporal o de detección de cambios Eastman et ál. (1994) precisan que, la técnica varía dependiendo si la imagen empleada es continua o categorizada. De este modo, para el caso de las continuas se han de emplear técnicas cuantitativas, entre las que destaca: diferencias, regresión, componentes principales, entre otras. Si la imagen es categorizada, es decir, imágenes previamente clasificadas, la técnica utilizada se dará mediante tablas de contingencia. 


\subsection{Matriz de Transición}

llustración 1: Matriz de transición para dos mapas de diferente fecha

\begin{tabular}{|c|c|c|c|c|c|c|c|}
\hline \multirow[b]{2}{*}{ Tiempo 1} & \multicolumn{5}{|c|}{ Tiempo 2} & \multirow[b]{2}{*}{6} & \multirow[b]{2}{*}{7} \\
\hline & 1 & 2 & 3 & 4 & 5 & & \\
\hline 1 & & Clase 1 & Clase 2 & ......... & Clase $\mathrm{n}$ & Total $T_{1}$ & Pérdidas $\left(L_{i j}\right)$ \\
\hline 2 & Clase 1 & & $P_{10}$ & ......... & $P_{\ln }$ & $P_{1+}$ & $P_{1+}-P_{11}$ \\
\hline 3 & Clase 2 & $P_{21}$ & & & $P_{2 \mathrm{n}}$ & $P_{2+}$ & $P_{2+}-P_{22}$ \\
\hline 4 & ….... & ........ & & & & (........ & ........... \\
\hline 5 & Clasen & $P_{\mathrm{n} 1}$ & $P_{\mathrm{n} 2}$ & $\cdots$ & $P_{\mathrm{nn}}$ & $P_{\mathrm{n}+}$ & $P_{\mathrm{n}+}-P_{\mathrm{nn}}$ \\
\hline 6 & Total $T_{2}$ & $P_{+1}$ & $P_{+2}$ & ......... & $P_{+\mathrm{n}}$ & $P$ & \\
\hline 7 & Ganancias $\left(G_{i j}\right)$ & $P_{+1}-P_{11}$ & $P_{+2}-P_{22}$ & $\ldots \ldots \ldots$ & $P_{+\mathrm{n}}-P_{\mathrm{nn}}$ & & \\
\hline
\end{tabular}

Fuente: Pontius, et al. (2004)

La matriz de transición Pontius et ál. (2004) la definen como aquella que resulta de cruzar dos mapas de diferente fecha, también se le conoce como matriz de tabulación cruzada. De acuerdo con López y Plata (2009) en dicha matriz (llustración 1) las filas representan las categorías del mapa en el tiempo 1 (T1) y las columnas las categorías del mapa en el tiempo 2 (T2).

Las áreas $(P)$ que no sufrieron cambios, es decir, las zonas estables (persistencias) entre T1 y T2, se presentan en la diagonal principal de la tabla (Pjj); los elementos fuera de la diagonal principal corresponden a las transiciones ocurridas entre categorías; la fila Total T2 (fila 6) indica el área total que ocupa cada clase en T2 $(P+n)$, mientras que la columna Total T1 (columna 6) representa el área total de cada categoría en el tiempo T1 $(P+n)$.

De esta manera, la fila 7, denominada ganancia bruta (Gij), indica la proporción del paisaje que experimentó un aumento entre el tiempo 1 y el tiempo 2 , es decir, la diferencia entre la columna de totales de la fila 6 y lo que permaneció estable. En lo que respecta a la columna 7, ésta corresponde a la pérdida bruta (Lij) que tuvo cada categoría entre T1 y T2, es decir, la diferencia entre Total T1 y los valores de la diagonal principal.

El dato, denominado "persistencia", se presenta en la diagonal principal de la matriz y además es importante para el cálculo de dos tipos de cambios: las ganancias y las pérdidas. Como se mencionó, estos datos sirven para el cálculo del intercambio, 
pero además para conocer el valor del "cambio total", el cual es el resultado de la suma entre las ganancias y las pérdidas, es decir, DTj = Gij + Lij. Estos datos permiten dimensionar el verdadero cambio sufrido por cada una de las categorías y saber si un paisaje es estable o está sufriendo cambios.

\subsection{Uso de Suelo}

Se entiende como la ocupación de este por cualquier actividad. Resultan ser una fiel expresión de las relaciones entre el ser humano y el medio que lo rodea. Se puede decir que en el paisaje se lee la historia (Sancho et ál., 1993). Según la Dirección General de Calidad y Evaluación Ambiental (DGAEA), los usos del suelo permiten identificar como es la dinámica de un territorio y su evolución, además, esta variable es utilizada también como indicador ambiental: “... las actividades humanas ejercen presiones sobre el medio y cambian su calidad y la cantidad de los recursos naturales. La sociedad responde a esos cambios mediante políticas ambientales, sectoriales y económicas..." (DGAEA, 1996).

\subsection{Coberturas de la tierra}

De acuerdo con el IDEAM (1997) se definen como las diferentes clases de vegetación que existen en un área determinada. Sus características están definidas por las condiciones climáticas, topográficas, edáficas, socioeconómicas y culturales propias de cada lugar. Es así, como se ha podido hacer diferencia entre los términos cobertura y uso de la tierra, puesto que anteriormente se usaban como sinónimos. Entonces, puede decirse que, el uso del suelo es la utilidad que presta determinado tipo de cobertura al ser humano.

\subsection{Metodología Corine Land Cover}

A partir de lo presentado por Mateo et ál. (2008) el programa CORINE surgió de manera experimental en 1985 y cuyo objetivo principal fue obtener y mantener actualizada información perteneciente a la cobertura y uso del suelo en el continente Europeo, todo lo anterior seria almacenado en una base de datos alfanumérica y geográfica con un nivel de detalle para una escala 1:100.000. Este programa busca la mejor forma para que la información sobre el estado del medio ambiente y los recursos naturales sea recolectada en un modo coordinado y homogéneo. 
Producto de este programa, entre 1985 y 1990, se dio la necesidad de desarrollar un sistema de información medioambiental para el que se estableció nomenclaturas y metodologías aprobadas en común acuerdo con los países de la comunidad europea en lo relacionado a la ocupación del suelo. Respecto a las metodologías mencionadas Suárez-Parra et ál. (2016), señalan que la metodología Corine Land Cover (CLC) tuvo un origen francés donde su objetivo fundamental deriva del programa CORINE y se realiza mediante análisis e interpretación de imágenes satelitales logrando de esta forma evaluar las coberturas de la tierra. Esta metodología busca el conocimiento de sus recursos naturales, evaluar las formas de ocupación y apropiación del espacio geográfico y finalmente mantener actualizada la información de la dinámica de las coberturas terrestres.

La metodología CLC fue adapta para Colombia por el IGAC, IDEAM Y CORMAGDALENA en compañía de profesionales del instituto Geográfico Nacional de Francia (IGNF) en el año 2008 mediante un proyecto Piloto para estandarizar el sistema de clasificación que concluyo con la elaboración de LA LEYENDA NACIONAL DE COBERTURA DE LA TIERRA; al respecto Martínez Vega (1996) menciona que la nomenclatura establecida para todos los territorios en cuanto a mapas de ocupación del suelo estará conformado por 44 clases, divididas estructural y jerárquicamente en 3 niveles; en donde cada país desarrolla la nomenclatura en función de sus características paisajísticas y medioambientales propias de su territorio.

\subsection{Programa LANDSAT}

Ilustración 2: Cronología del Programa LANDSAT

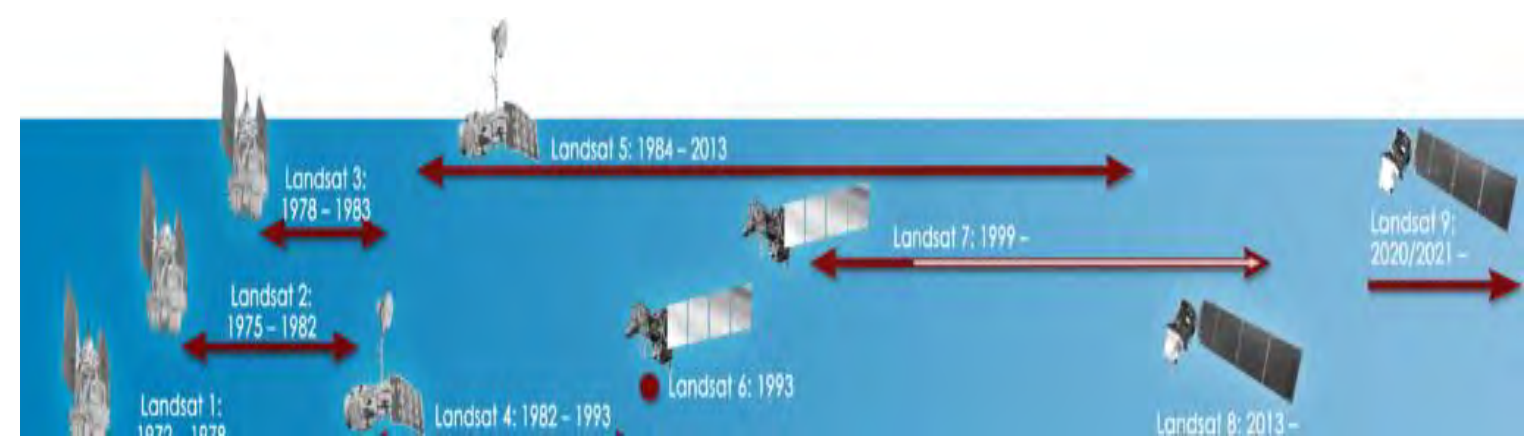

Fuente: $\underline{\text { https://landsat.gsfc.nasa.gov/a-landsat-timeline/ }}$ 
El primer satélite del Proyecto LANDSAT se puso en órbita en julio de 1972 en principio identificado dentro de la serie ERTS (Earth Resource Technollogy Satellite), por su sigla en inglés, esto de acuerdo a Chuvieco (2008), posteriormente y hasta la fecha se ha denominado como LANDSAT, con 8 lanzamientos más (llustración 2),

Tabla 1 Características LANDSAT 4- TM Thematic Mapper

\begin{tabular}{|c|c||}
\hline \multicolumn{2}{|c||}{ Disponibilidad } \\
\hline Lanzamiento & $16 / 07 / 1982$ \\
\hline Fin de trasmisión & 1993 \\
\hline Desmantelamiento & $15 / 06 / 2001$ \\
\hline \multicolumn{2}{|c||}{ Resolución } \\
\hline Espacial & $30 \mathrm{~m}$ \\
\hline Temporal & 9:45 hora solar $+/$ - 15 minutos \\
\hline Espectral & 7 bandas \\
& (3 Rango Visible-4 Infrarrojo) $)$ \\
\hline Radiométrica & 8 bits \\
\hline Ancho de Barrido & 185 km \\
\hline \multicolumn{2}{|c||}{ Característica orbital } \\
\hline Inclinación & $98.2^{\circ}$ \\
\hline Orbita & Helio síncrona, polar \\
\hline Altura de vuelo & 705 km \\
\hline Periodo Orbital & 98.9 minutos - 14.5 orbitas/día \\
\hline \multicolumn{2}{|c|}{ Instrumentos } \\
\hline TM & Thematic Mapper \\
\hline MSS & Multispectral Scanner \\
\hline
\end{tabular}

Fuente: Elaboración de la autora a partir de información de la USGS y la NASA

Como se explicará en la recopilación de la información, la adquisición de la imagen satelital para la época de 1988 resulto en una imagen procedente del LANDSAT 4 TM, por esta razón se hace una mención de éste en donde se indica sus características más representativas (Tabla 1), de acuerdo con el United States Geological Survey (USGS) su lanzamiento en 1982 es destacado por las mejoras en su diseño y en el uso del mapeador temático (TM) dentro de sus instrumentos a 
bordo (USGS a, 2018) y adicionalmente la National Aeronautics and Space Administration (NASA) resalta la eliminación de las cámaras de video o RBV instrument (NASA, 2019).

\subsubsection{Thematic Mapper TM}

El Mapeador Temático es un escáner multiespectral avanzado, para el monitoreo de recursos naturales, este es un sensor de tipo opto-mecanico con rango espectral que va de 0.45 a $12.5 \mu \mathrm{m}$ (NASA, 2019) este instrumento cuenta con mejor resolución espectral y espacial respecto al sensor MSS, permitiendo ver la cobertura superficial con mejor detalle e incluye una banda termal. Presenta 7 bandas espectrales con resolución espacial de 30 metros excepto la banda 6 que es de 120 metros y su lente logra un ancho de barrido de 185 km (USGS a, 2018).

\subsection{Sentinel}

Los satélites Sentinel (1 a 6) fueron desarrollados para la recolección de información terrestre mediante teledetección en el marco del programa Copernicus de la Comisión Europea (USGS b, 2018). Según la Agencia Espacial Europea (ESA), por sus siglas en inglés, cada Misión de Sentinel está enfocada a diferentes aspectos de observación terrestre: Atmosférica, Oceánica y monitoreo de la superficie (ESA b, 2020).

La imagen seleccionada para el análisis multitemporal en 2018, corresponde a la misión de Sentinel 2, razón por la cual se amplía respecto a esta última: Esta misión tiene como objetivo el monitoreo de la superficie mediante el uso de 2 satélites, separados $180^{\circ}$, con orbita helio síncrona (Tabla 2) que entregan como resultado imágenes en alta resolución, se estima una vida útil de mínimo 7 años, un hecho destacable es su tiempo de revisita de 5 días al combinar la constelación de satélites en la zona ecuatorial siempre y cuando haya condiciones de baja nubosidad (ESA b, 2020)

Tabla 2 Características SENTINEL 2- MSI MultiSpectral Instrument

\begin{tabular}{|c|c|}
\hline \multicolumn{2}{|c|}{ Disponibilidad } \\
\hline \multirow{2}{*}{ Lanzamiento } & $23 / 06 / 2015$ (Sentinel 2A) \\
& $07 / 03 / 2017$ (Sentinel 2B) \\
\hline \multicolumn{2}{|c|}{ Resolución } \\
\hline
\end{tabular}




\begin{tabular}{|c|c|}
\hline Espacial & $\begin{array}{c}10 \text { m (Bandas 2,3,4,8) } \\
\text { m (Bandas } 5,6,7,8 a, 11,12) \\
60 \text { m (Bandas 1,9,10) }\end{array}$ \\
\hline Temporal & $\begin{array}{c}10 \text { días } \\
10: 30 \text { hora local }\end{array}$ \\
\hline Espectral & $\begin{array}{c}13 \text { bandas } \\
\text { (4 Rango Visible-9 Infrarrojo) }\end{array}$ \\
\hline Radiométrica & 12 bits \\
\hline Ancho de Barrido & 290 km \\
\hline \multicolumn{2}{|c|}{ Característica orbital } \\
\hline Inclinación & $98.62^{\circ}$ \\
\hline Orbita & Helio síncrona \\
\hline Altura de vuelo & 786 km \\
\hline Periodo Orbital & 100.6 minutos \\
\hline \multicolumn{2}{|c|}{ Instrumento } \\
\hline MSI & MultiSpectral Instrument \\
\hline
\end{tabular}

Fuente: Elaboración de la autora a partir de información de la USGS y ESA

\subsubsection{Multispectral Instrument}

Este sensor utiliza el concepto de escobilla (push broom) para la adquisición de las imágenes en 13 bandas con un rango espectral que va de $443 \mathrm{~nm}$ a $2190 \mathrm{~nm} .4$ de estas con resolución espacial de 10 metros, 6 con 20 metros y 3 de 60 metros, sus principales aplicaciones están dadas para el monitoreo de agricultura, bosques, detección de cambios en el uso y cobertura del suelo, mapeo de variables biofísicas, monitoreo de las costas así como aguas internas y el mapeo de riesgos y desastres (ESA a, 2020)

\subsubsection{Nivel de Procesamiento}

Los productos obtenidos del Sentinel 2 son distribuidos con valores de reflectancia en el techo de la Atmosfera TOA, se ha denominado Level-1C, este proceso incluye correcciones radiométricas y geométricas junto con la ortorectificación (USGS b, 2018). 


\subsubsection{Reflectancia en el Techo de la Atmósfera (TOA)}

Según describe Cogedo (2016), permite combinar la reflectancia de la superficie y la reflectancia atmosférica, para reducir la variabilidad inter-imagen a través de una normalización de la irradiancia solar. Esta reflectancia TOA $(\rho p)$, la cual es la ratio de la energía reflejada con respecto al total de la energía incidente (USGS a, 2019), puede ser calculada como:

$$
\rho_{\rho}=\frac{\pi * L_{\lambda} * d^{2}}{\operatorname{ESUN} \lambda * \cos \cos \theta s}
$$

Donde:

$\mathrm{L}_{\lambda}=$ Radiancia espectral en el sensor (Radiancia en el satélite)

$d=$ Distancia Tierra-Sol en Unidades Astronómicas (la cual se encuentra en el archivo de metadatos)

ESUN $=$ Irradiancia Media Solar exo-atmosférica

$\theta s=$ Angulo zenital solar en grados, el cual es equivalente a: $\theta s=90^{\circ}-\theta e$ donde $\theta e$ es la elevación solar.

Las imágenes Sentinel-2 se distribuyen ya con valores de reflectancia TOA escalados, los cuales pueden ser convertidos a reflectancia TOA con un cálculo simple utilizando el Valor de Discretización provisto en los metadatos (ESA b, 2015).

\subsubsection{Corrección Dos}

Dark Object Substraction (DOS) o substracción de objeto oscuro es una familia de correcciones atmosféricas basadas en imagen, este procedimiento es conocido como el Método de Chávez o substracción de píxeles oscuros, el cual toma la reflectancia aparente como resultado de la dispersión atmosférica y ajusta la imagen respecto a los valores inferiores de reflectancia explica Cogedo (2016) y adicionalmente resalta que las imágenes Sentinel son convertidas a radiancia antes de realizar la corrección DOS.

Chávez (1996) la describe de la siguiente forma:

La suposición básica es que en la imagen algunos píxeles están completamente en sombra, y sus radiancias recibidas en el satélite se deben a la dispersión atmosférica 
(efecto bruma). Esta suposición es combinada con el hecho de que muy pocos elementos en la superficie de la Tierra tienen un color negro absoluto, por lo tanto, una reflectancia asumida de uno por ciento es mejor que un cero por ciento. Es importante mencionar que la exactitud de las técnicas basadas en imagen es generalmente menor que las correcciones basadas en medidas físicas, pero son muy útiles cuando no están disponibles mediciones atmosféricas que puedan mejorar la estimación de la reflectancia de la superficie terrestre (p. 1027).

\section{LOCALIZACIÓN DEL ÁREA DE ESTUDIO}

San Francisco de Sales está ubicado en la Provincia del Gualivá en el centro del Departamento de Cundinamarca. Su extensión total es de 118,2 Km², la altitud de la cabecera municipal es 1.520 msnm. Limita al Norte con los municipios de La Vega y Supatá, al Oriente con los municipios de Subachoque y El Rosal, al Sur con el municipio de Facatativá. Occidente: Municipio de La Vega. (Alcaldía Municipal de San Francisco Cundinamarca, Acuerdo Municipal No. 012 de 2016 )

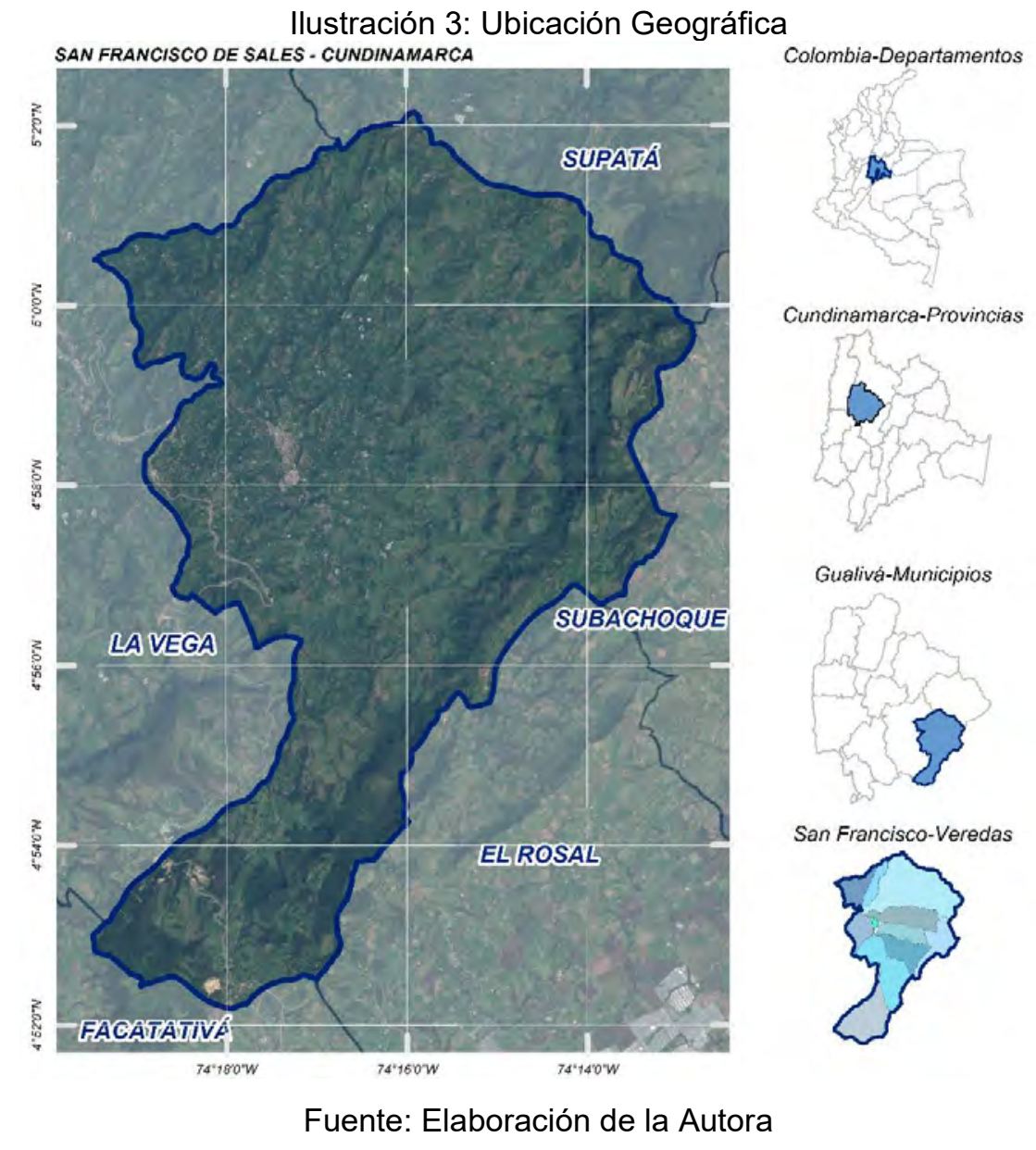


El municipio se encuentra a un costado de la principal vía de acceso a Bogotá D.C por el occidente del país, ubicado a $56,4 \mathrm{Km}$ de esta. Constituyendo el municipio de clima templado más cercano a la capital, presenta una temperatura promedio de $20^{\circ} \mathrm{C}$ en la mayor parte del territorio, con una precipitación media anual de 1.493 $\mathrm{mm}$ lo cual lo hace un lugar atractivo para el turismo y recurso hídrico. San Francisco presenta un relieve montañoso, destacándose los fenómenos orográficos como los altos de la Clavija, Mapura, Redondo y Yaqué; también la cordillera de la Cabrilla, los Cerros de Buenavista y el Peñón.

\section{Ilustración 4: División Política}

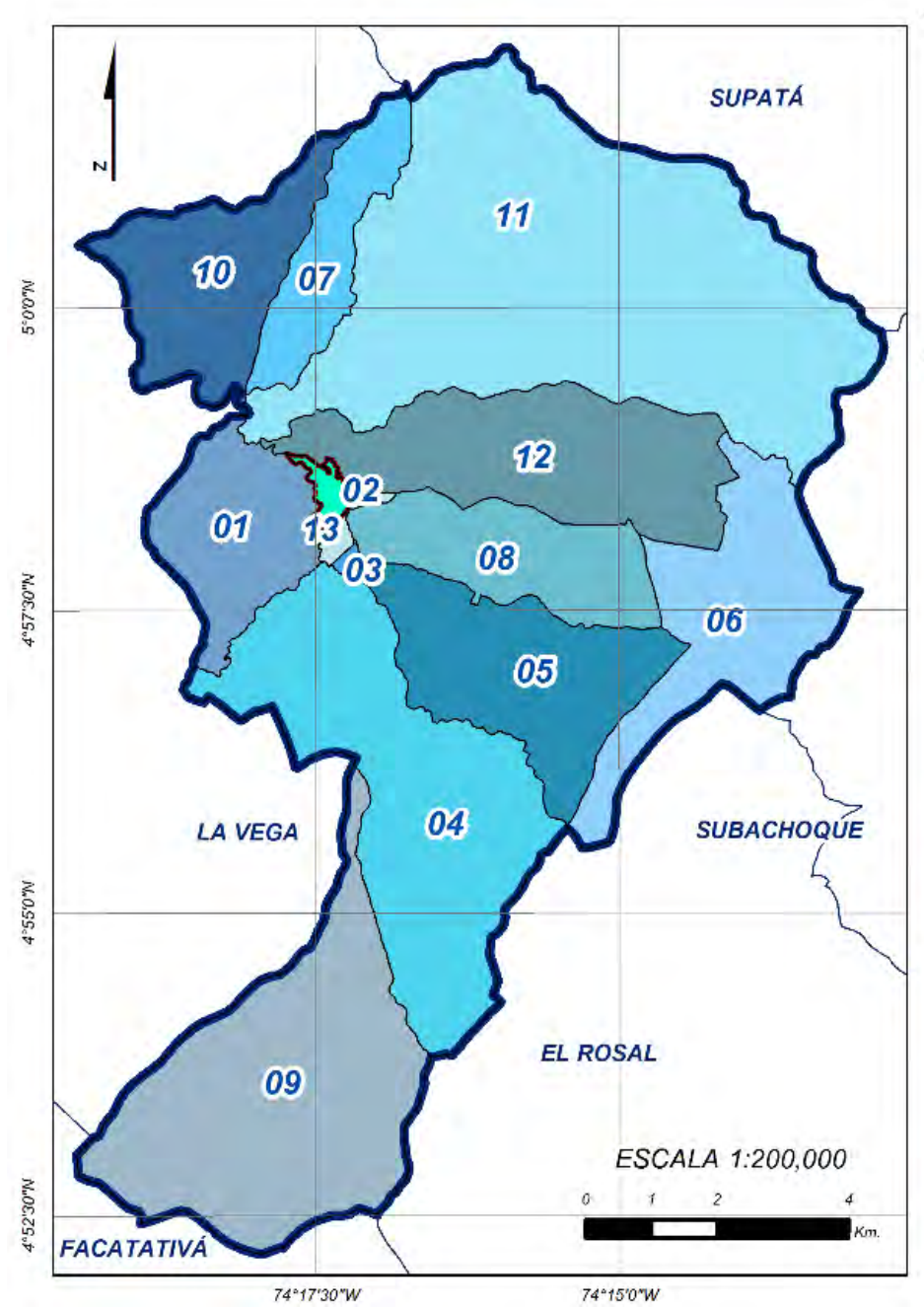

LOCALIZACIÓN GENERAL

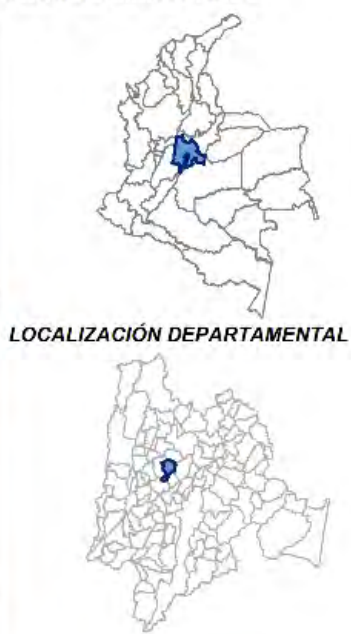

VEREDA

01. ARRAYÁN

02. CENTRO 1

03. CENTRO 2

04. EL PEÑON

05. JUAN DE VERA

06. LA LAJA

07. MUÑA

08. PUEBLO VIEJO

09. SABANETA

10. SAN ANTONIO

11. SAN MIGUEL

12. TORIBA

13. PERIMETRO URBANO

Fuente: Elaboración de la Autora a partir de información del Consejo Municipal de San Francisco Cundinamarca (Acuerdo Municipal No. 21 de 1999) 


\section{METODOLOGÍA}

Se establecieron las fases necesarias para la ejecución del proyecto, el cual estuvo basado principalmente en un análisis multitemporal con imágenes satelitales y software especializados como QGIS, ARGIS y ENVI para la obtención de los datos necesarios en la identificación de cambios en el uso del suelo, como consecuencia de la evolución del medio natural o las repercusiones de la acción humana sobre este último.

A continuación, se presenta el resumen metodológico de trabajo basado en la entrada, proceso y salida de datos e información (llustración 5) utilizados en el desarrollo de este trabajo; seguido de la descripción en detalle de los procedimientos. 


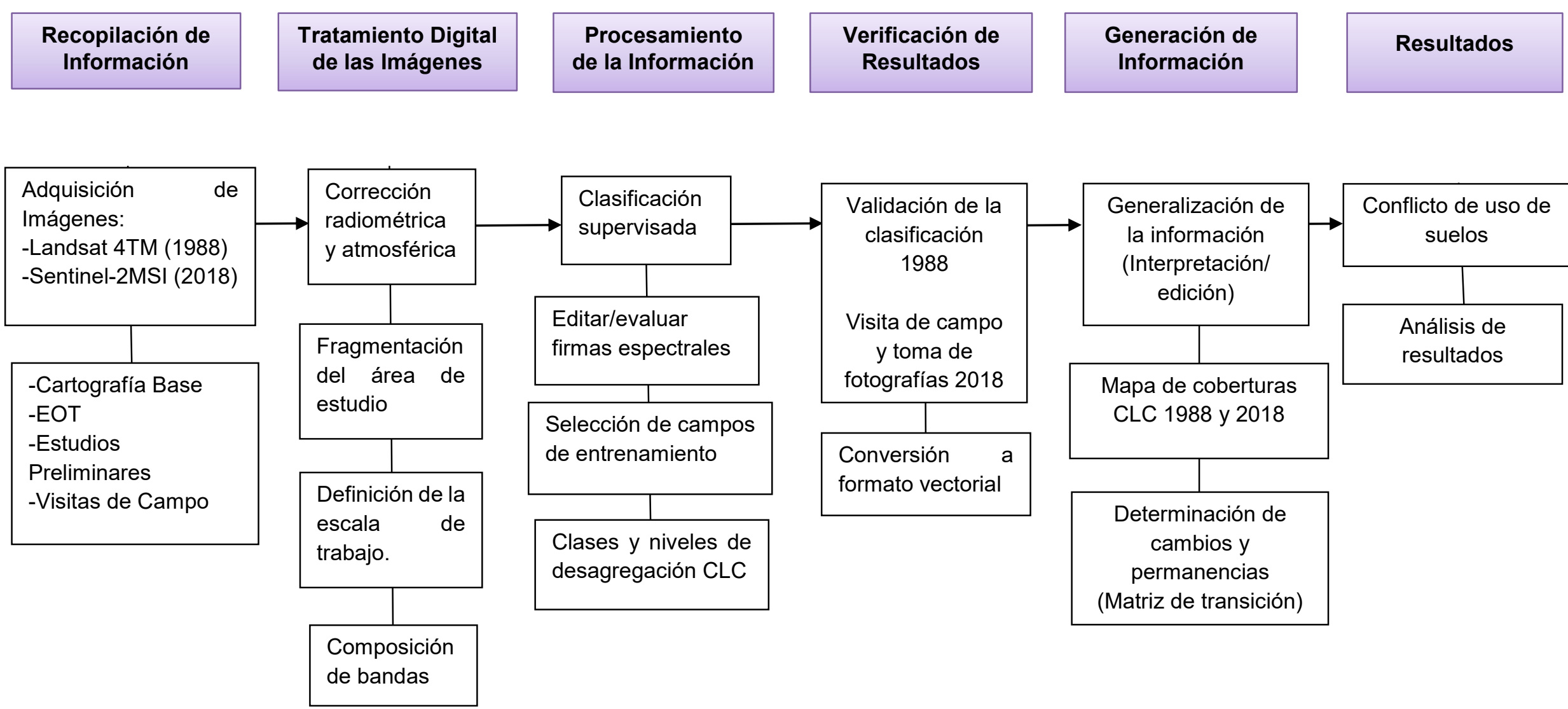

Fuente: Elaboración de la autora 


\subsection{Recopilación de la Información}

Se lleva a cabo con el fin de corroborar la información inicial disponible de la zona de estudio y recopilar los elementos necesarios para llevar a buen término la tesis y evitar redundancia en la información. La búsqueda se hizo inicialmente en las bases de datos de corporaciones y entidades estatales como el IGAC, IDEAM, CORMAGDALENA, la Gobernación de Cundinamarca, entre otros, quienes ponen a disposición del público la información que les concierne a través de sus páginas web oficiales y de forma gratuita en su mayoría.

Posteriormente se hizo la búsqueda, selección y adquisición de las imágenes satelitales de acceso libre y gratuito para las épocas de interés con path 8 y row 57 , las cuales se obtuvieron desde el servicio web Earth Explorer del Departamento Geológico de los Estados Unidos de Norte América- USGS (Ilustración 6). Para la elección de las imágenes, se verificó que posean características climáticas equivalentes y de esta manera asegurar que las firmas espectrales de las coberturas presentes tengan un comportamiento similar. De acuerdo a lo mencionado y por el bajo cubrimiento de nubes, se eligieron Enero (2018) y Marzo (1988) para llevar a cabo el estudio, dado que, según Climate-Data (2020) San Francisco presenta un régimen de lluvias con precipitaciones significativas la mayoría de los meses y una estación seca corta entre Julio y Agosto. 
Ilustración 6: Escena de imágenes descargadas

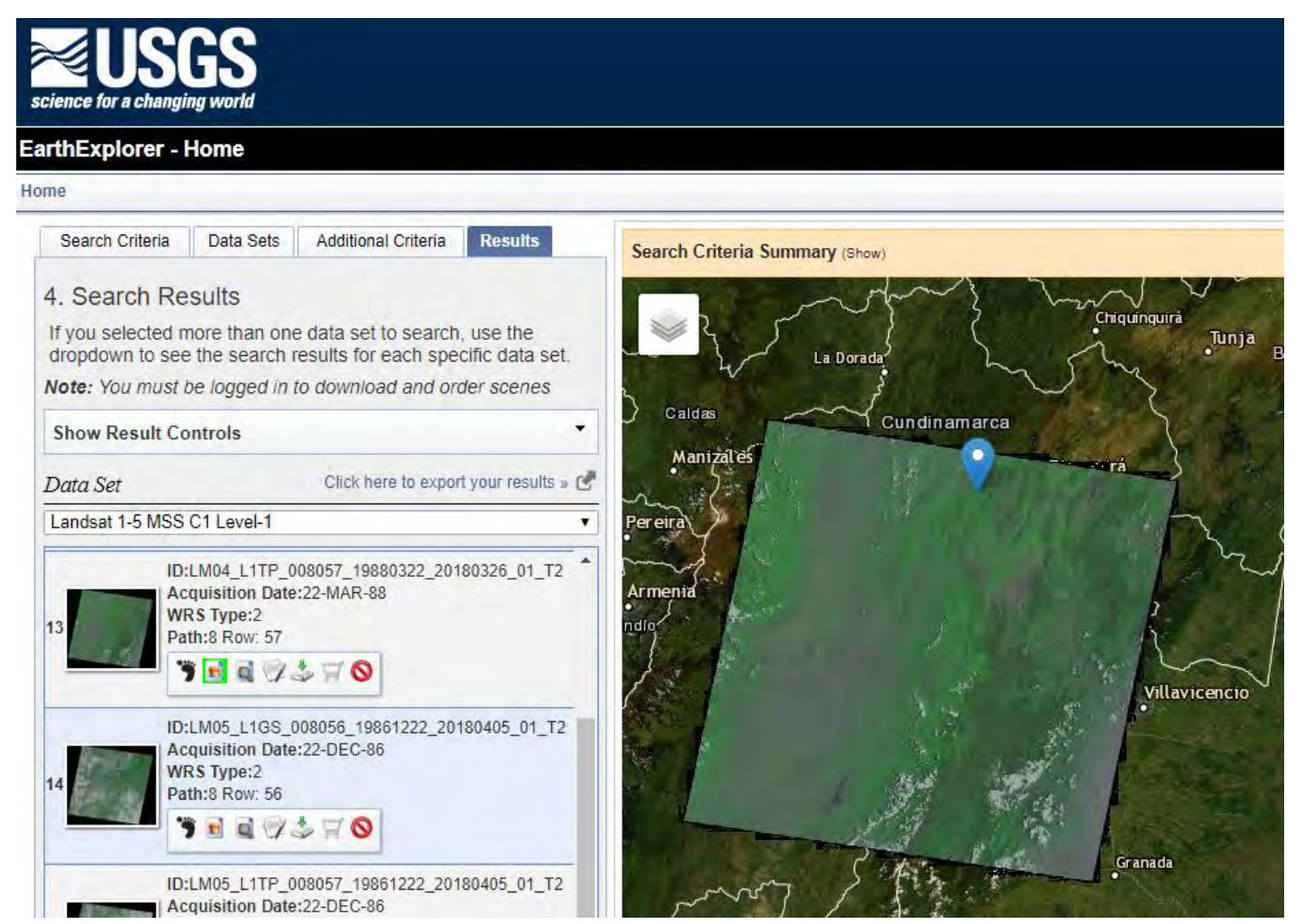

Fuente: https://earthexplorer.usgs.gov/

En la Tabla 3, se enlistan los insumos utilizados en este estudio:

Tabla 3 Insumos

\begin{tabular}{|l|l|l|l|}
\hline \multicolumn{1}{|c|}{ Insumo } & \multicolumn{1}{|c|}{ Escala } & Formato & \multicolumn{1}{|c|}{ Fuente } \\
\hline $\begin{array}{l}\text { Cartografía Base/Limites } \\
\text { Municipales }\end{array}$ & $1: 100.000$ & Shape & IGAC \\
\hline $\begin{array}{l}\text { Memoria Técnica Uso actual y } \\
\text { cobertura vegetal año 1993. }\end{array}$ & No Aplica & PDF & $\begin{array}{l}\text { Gobernación de } \\
\text { Cundinamarca }\end{array}$ \\
\hline $\begin{array}{l}\text { Planchas de Unidades de uso de } \\
\text { suelo y coberturas 1993 }\end{array}$ & $1: 25.000$ & PDF & $\begin{array}{l}\text { Gobernación de } \\
\text { Cundinamarca }\end{array}$ \\
\hline $\begin{array}{l}\text { Leyenda Nacional de Coberturas } \\
\text { de La Tierra. Metodología Corine } \\
\text { Land Cover Adoptada Para } \\
\text { Colombia Escala 1:100.000. }\end{array}$ & No Aplica & PDF & $\begin{array}{l}\text { IDEAM, } \\
\text { CORMAGDALE } \\
\text { NA, IGAC. }\end{array}$ \\
\hline
\end{tabular}




\begin{tabular}{|c|c|c|c|}
\hline Insumo & Escala & Formato & Fuente \\
\hline $\begin{array}{l}\text { Informe Técnico sobre la } \\
\text { elaboración y edición de la } \\
\text { cartografía digital de la } \\
\text { clasificación del suelo y los usos } \\
\text { del suelo rural de conformidad con } \\
\text { el plan de ordenamiento territorial } \\
\text { para los municipios del } \\
\text { departamento de Cundinamarca. }\end{array}$ & No Aplica & PDF & $\begin{array}{l}\text { Gobernación de } \\
\text { Cundinamarca }\end{array}$ \\
\hline $\begin{array}{l}\text { Usos propuestos del suelo de } \\
\text { conformidad con el plan de } \\
\text { ordenamiento territorial para los } \\
\text { municipios del departamento de } \\
\text { Cundinamarca. }\end{array}$ & 1:100.000 & Shape & $\begin{array}{l}\text { Gobernación de } \\
\text { Cundinamarca }\end{array}$ \\
\hline $\begin{array}{l}\text { Acuerdo No } 21 \text { de } 1999 \text { Esquema } \\
\text { de Ordenamiento Territorial. San } \\
\text { Francisco, Cundinamarca }\end{array}$ & No Aplica & PDF & $\begin{array}{l}\text { Consejo } \\
\text { Municipal- } \\
\text { Oficina De } \\
\text { Planeación } \\
\text { Municipal }\end{array}$ \\
\hline $\begin{array}{l}\text { Acuerdo Municipal No. } 012 \text { de } \\
2016 \text {-Plan de Desarrollo "Súmate } \\
\text { al Cambio 2016-2019" }\end{array}$ & No Aplica & PDF & $\begin{array}{l}\text { Alcaldía } \\
\text { Municipal de San } \\
\text { Francisco } \\
\text { Cundinamarca }\end{array}$ \\
\hline \multicolumn{4}{|l|}{ Imágenes Satelitales } \\
\hline $\begin{array}{l}\text { Landsat } 4 \\
\text { (LT04_L1TP_008057_19880322) }\end{array}$ & $30 \mathrm{~m}$ & Raster & USGS \\
\hline $\begin{array}{l}\text { Sentinel } 2 \\
\text { (S2B_MSIL1C_20180124T152629 }\end{array}$ & $\begin{array}{l}10,20 \text { y } 60 \\
m\end{array}$ & Raster & USGS \\
\hline
\end{tabular}

Fuente: Elaboración de la autora 
Las características de las imágenes utilizadas se muestran en la Tabla 4 y Tabla 5:

Tabla 4: Resoluciones del sensor Landsat 4 Fecha de captura 22/03/1988

\begin{tabular}{|c|c|c|c|}
\hline Nombre Archivo & Bandas Landsat 4 & $\begin{array}{c}\text { Longitud de } \\
\text { Onda } \\
\text { (micrómetros) }\end{array}$ & $\begin{array}{c}\text { Resolución } \\
\text { (metros) }\end{array}$ \\
\hline $\begin{array}{c}\text { LT04_L1TP_008057_19880322 } \\
\text { 20170209_01_T1_B1 }\end{array}$ & Banda 1 - Azul & $0.45-0.52$ & 30 \\
\hline $\begin{array}{c}\text { LT04_L1TP_008057_19880322 } \\
\text { 20170209_01_T1_B2 }\end{array}$ & Banda 2 - Verde & $0.52-0.60$ & 30 \\
\hline $\begin{array}{c}\text { LT04_L1TP_008057_19880322 } \\
\text { 20170209_01_T1_B3 }\end{array}$ & Banda 3 - Rojo & $0.63-0.69$ & 30 \\
\hline $\begin{array}{c}\text { LT04_L1TP_008057_19880322 } \\
\text { 20170209_01_T1_B4 }\end{array}$ & $\begin{array}{c}\text { Banda 4 - Infrarrojo } \\
\text { Cercano (NIR) }\end{array}$ & $0.76-0.90$ & 30 \\
\hline $\begin{array}{c}\text { LT04_L1TP_008057_19880322 } \\
\text { 20170209_01_T1_B5 }\end{array}$ & Banda 5 - SWIR & $1.55-1.75$ & 30 \\
\hline $\begin{array}{c}\text { LT04_L1TP_008057_19880322 } \\
\text { 20170209_01_T1_B6 }\end{array}$ & Banda 6 - Infrarrojo & $10.40-12.50$ & (remuestreada \\
Térmico & a 30) \\
\hline $\begin{array}{c}\text { LT04_L1TP_008057_19880322 } \\
\text { 20170209_01_T1_B7 }\end{array}$ & Banda 7 - SWIR & $2.08-2.35$ & 30 \\
\hline
\end{tabular}

Fuente: www.usgs.gov/landsat

Tabla 5: Resoluciones del sensor Sentinel-2

Fecha de captura 24/01/2018

\begin{tabular}{|c|c|c|c|}
\hline Nombre Archivo & $\begin{array}{c}\text { Bandas } \\
\text { Sentinel-2 }\end{array}$ & $\begin{array}{c}\text { Longitud de } \\
\text { Onda Central } \\
\text { (micrómetros) }\end{array}$ & $\begin{array}{c}\text { Resolución } \\
\text { (metros) }\end{array}$ \\
\hline RT_T18NWL_20180124T152629_B01 & $\begin{array}{c}\text { Banda 1 - } \\
\text { Coastal } \\
\text { aerosol }\end{array}$ & 0.443 & 60 \\
\hline RT_T18NWL_20180124T152629_B02 & $\begin{array}{c}\text { Banda 2 - } \\
\text { Azul }\end{array}$ & 0.490 & 10 \\
\hline RT_T18NWL_20180124T152629_B03 & $\begin{array}{c}\text { Banda 3 - } \\
\text { Verde }\end{array}$ & 0.560 & 10 \\
\hline RT_T18NWL_20180124T152629_B04 & $\begin{array}{c}\text { Banda 4 - } \\
\text { Rojo }\end{array}$ & 0.665 & 20 \\
\hline RT_T18NWL_20180124T152629_B05 & $\begin{array}{l}\text { Banda 5 - } \\
\text { Vegetation } \\
\text { Red Edge }\end{array}$ & 0.705 & 20 \\
\hline RT_T18NWL_20180124T152629_B06 & $\begin{array}{l}\text { Banda 6 - } \\
\text { Vegetation } \\
\text { Red Edge }\end{array}$ & 0.740 & 20 \\
\hline RT_T18NWL_20180124T152629_B07 & $\begin{array}{c}\text { Banda 7 - } \\
\text { Vegetation } \\
\text { Red Edge }\end{array}$ & 0.783 & 20 \\
\hline
\end{tabular}




\begin{tabular}{|l|c|c|c|}
\hline Nombre Archivo & $\begin{array}{c}\text { Bandas } \\
\text { Sentinel-2 }\end{array}$ & $\begin{array}{c}\text { Longitud de } \\
\text { Onda Central } \\
\text { (micrómetros) }\end{array}$ & $\begin{array}{c}\text { Resolución } \\
\text { (metros) }\end{array}$ \\
\hline RT_T18NWL_20180124T152629_B08 & $\begin{array}{c}\text { Banda 8 - } \\
\text { NIR }\end{array}$ & 0.842 & 10 \\
\hline RT_T18NWL_20180124T152629_B08A & $\begin{array}{c}\text { Banda 8A - } \\
\text { Vegetation } \\
\text { Red Edge }\end{array}$ & 0.865 & 20 \\
\hline RT_T18NWL_20180124T152629_B09 & $\begin{array}{c}\text { Banda 9 - } \\
\text { Water } \\
\text { vapour }\end{array}$ & 0.945 & 60 \\
\hline RT_T18NWL_20180124T152629_B10 & $\begin{array}{c}\text { Banda 10 - } \\
\text { SWIR - } \\
\text { Cirrus }\end{array}$ & 1,375 & 60 \\
\hline RT_T18NWL_20180124T152629_B11 & $\begin{array}{c}\text { Banda 11 - } \\
\text { SWIR }\end{array}$ & 1,610 & 20 \\
\hline RT_T18NWL_20180124T152629_B12 & $\begin{array}{c}\text { Banda 12 - } \\
\text { SWIR }\end{array}$ & 2,190 & 20 \\
\hline
\end{tabular}

Fuente: https://scihub.copernicus.eu.

Para la estandarización de las variables espaciales, y en cumplimiento con la normatividad nacional adoptada para Colombia por el Instituto Geográfico Agustín Codazzi-(IGAC), se aplicó a toda la cartografía temática la referencia espacial MAGNA SIRGAS, que garantiza la compatibilidad con las técnicas espaciales de posicionamiento y las normas internacionales de datos georreferenciados.

Tabla 6: Registro de Parámetros Geodésicos

\begin{tabular}{|l|l|}
\hline \multicolumn{2}{|c|}{ DATUM MAGNA SIRGAS } \\
\hline Elipsoide de Referencia & GRS80 \\
\hline Semieje mayor & 6378137 \\
\hline Relación de achatamiento & $1 / 298,257222101$ \\
\hline Datum de Altitud & Buenaventura \\
\hline Resol. y unidades de distancia & $0,001 \mathrm{~m}$ \\
\hline Factor de Escala & 1 \\
\hline Falso Este & $1^{\prime} 000.000$ \\
\hline Falso Norte & $1^{\prime} 000.001$ \\
\hline
\end{tabular}

Fuente: Elaboración de la autora a partir de información del IGAC

Con la información seleccionada y recopilada, se procedió a constituir la base de datos geográfica para el posterior procesamiento de los insumos que la componen, 
realizando la edición, estructuración y definición de atributos conforme lo demandó este estudio, lo anterior se almacenó en el software ArcGis 10.5, esto con el objetivo de obtener y utilizar de una forma sencilla, ordenada y práctica toda la información concerniente a este trabajo (Ilustración 7).

Ilustración 7: Geodatabase con los insumos y resultados del estudio Multitemporal

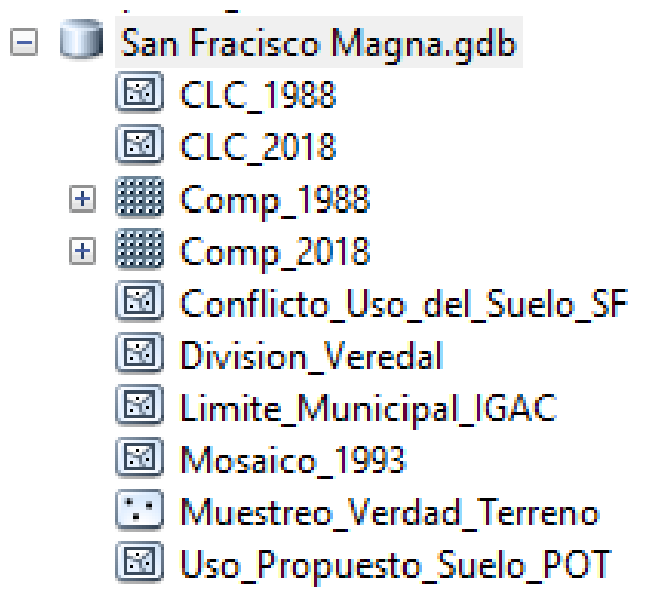

Fuente: Elaboración de la autora

\subsection{Pre-procesamiento de las Imágenes de Satélite}

Esta etapa incluye los procesos para las mejoras de las características de las imágenes descargadas, con el fin de corregir los errores presentes y optimizar su calidad.

Las imágenes se descargaron en formato GEOTIFF y poseen un nivel de preprocesamiento denominado L1T en el caso de Landsat y L1C para Sentinel. Dichos niveles incluyen correcciones radiométricas y geométricas mediante la incorporación de puntos de control GPC's y también orto-rectificación a través del Modelo Digital de Elevación (MDE), esta información puede ser verificada accediendo al metadato respectivo de cada imagen (Ilustración 8). De igual manera se hizo una comprobación a través de la superposición de las escenas y la base cartográfica, de ríos y vías a escala 1:100.000, georreferenciadas en el sistema MAGNA SIRGAS del IGAC. 
Ilustración 8: Metadato de la imagen

\begin{tabular}{|c|c|c|}
\hline ] LT04_L1TP_008057_19880322_20170209_01_T1_MTL: Bloc de nota & Raster Dataset Properties & \\
\hline Archivo Edición Formato Ver Ayuda & General Key Metadata & \\
\hline REFLECTANCE_ADD_BAND_7 $=-0.008096$ & Property & Value \\
\hline END_GROUP $=$ RADIOMETRIC_RESCALING & $\boxminus \quad$ Data Source & value \\
\hline GROUP $=$ THERMAL_CONSTANTS & Raster & T18NWL_20180124T152629_B02.jp2 \\
\hline K1_CONSTANT_BAND_6 $=671.62$ & Data Type & File System Raster \\
\hline K2_CONSTANT_BAND_6 $=1284.30$ & Folder & C: Analisis Multitemporal San Francisce \\
\hline END_GROUP = THERMAL_CONSTANTS & \pm Raster Information & \\
\hline GROUP $=$ PROJECTION_PARAMETERS & \pm Extent & \\
\hline MAP_PROJECTION $=$ "UTM" & $\because \quad$ Spatial Reference & \\
\hline DATÜM = "WGS84" & $\begin{array}{l}\text { XY Coordinate System } \\
\text { Linear Unit }\end{array}$ & $\begin{array}{l}\text { WGS_1984_UTM_Zone_18N } \\
\text { Meter }(1,000000)\end{array}$ \\
\hline ELLIPSOID = "WGS84" & Angular Unit & Degree $(0,0174532925199433)$ \\
\hline UTM_ZONE = 18 & False_Easting & 500000 \\
\hline GRID_CELL_SIZE_REFLECTIVE $=30.00$ & False_Northing & 0 \\
\hline GRID_CELL_SIZE_THERMAL $=30.00$ & Central_Meridian & -75 \\
\hline ORIENTATION = "NORTH UP" & Scale_Factor & 0,9996 \\
\hline RESAMPLING_OPTION = "CUBIC_CONVOLUTION" & Latitude_Of_Origin & 0 \\
\hline MAP PROJECTION LORA $=$ "NA" & Vertical Coordinate S... & $D_{-} 6000_{-} 1904$ \\
\hline END_GROUP $=$ PROJECTION_PARAMETERS & $\boxminus$ Statistics & \\
\hline END_GROUP = L1_METADATA_FILE & & \\
\hline $\mathrm{END}^{-}+\mathrm{C}^{-}+$ & & Aceptar \\
\hline
\end{tabular}

Fuente: Elaboración de la autora a partir de información del archivo MTL de Landsat-4.

\subsubsection{Corrección Radiométrica y Atmosférica}

Son las técnicas que se utilizan para modificar los niveles digitales (ND) originales con el fin de acercarlos a los que tendrían que estar presentes en la imagen si hubiese una recepción ideal por parte del sensor del satélite.

De acuerdo con Cabera et ál, IDEAM (2011) estos procesos de corrección permiten convertir la información de la imagen original de cada píxel, de Niveles Digitales ND- a valores de reflectancia captada por el sensor en el tope de la atmósfera, es decir, sin los efectos de esta, lo que permite disminuir los efectos de dispersión o absorción causados por la presencia de partículas en la atmósfera. También se busca remover el efecto de los diferentes ángulos de incidencia de la energía solar y de la distancia de la tierra - sol, que se producen como consecuencia de las diferencias de tiempo de adquisición de las escenas. En general, se intenta minimizar los errores que influyen en la radiación o en el valor radiométrico de cada elemento captado.

Para este proceso, se utilizó la herramienta Semi automátic classification plugin Pre processing- Sentinel 2 y LANDSAT conversion del software QGis 3.8.1 ( llustración 9 e llustración 10), la cual convierte los ND a valores de reflectancia TOA 
y temperatura de brillo. Como resultado final de este sub- proceso, se obtiene una imagen en valores de reflectancia que mejora la separabilidad espectral de los objetos presentes en la imagen corregida respecto de la original, optimizando los resultados finales del proceso de clasificación digital.

Ilustración 9: Configuración de las correcciones utilizadas en QGis para Landsat 4.

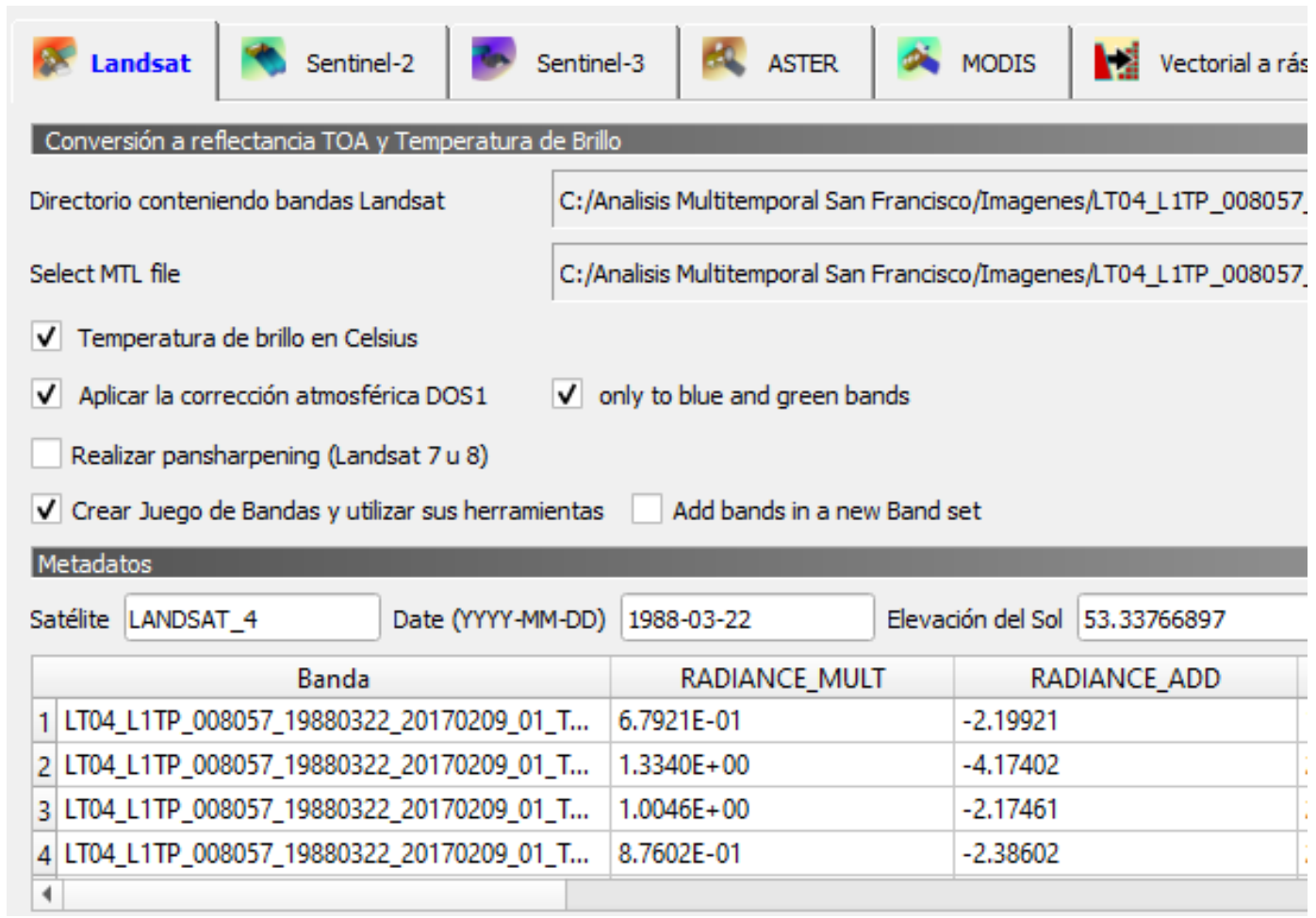

Fuente: QGis 3.8.1

Cogedo menciona respecto a las escenas de Landsat y Sentinel-2 que están compuestas de diferentes bandas y un archivo de metadatos que contiene la información necesaria para el cálculo de la reflectancia (2016). La USGS b, señala además que las imágenes Landsat están provistas en radiancia lo cual es previamente escalado al resultado (2019).

En la llustración 9 se puede observar la corrección realizada a la imagen de Landsat 4, allí se aplica la conversión a reflectancia TOA y de temperatura de brillo, también se selecciona la corrección atmosférica DOS1, todo lo anterior se efectúa con el objetivo de obtener imagen mejorada que permita optimizar la separabilidad espectral en los procesos posteriores de clasificación digital. 
Ilustración 10: Configuración de las correcciones utilizadas en QGis para Sentinel 2MSI

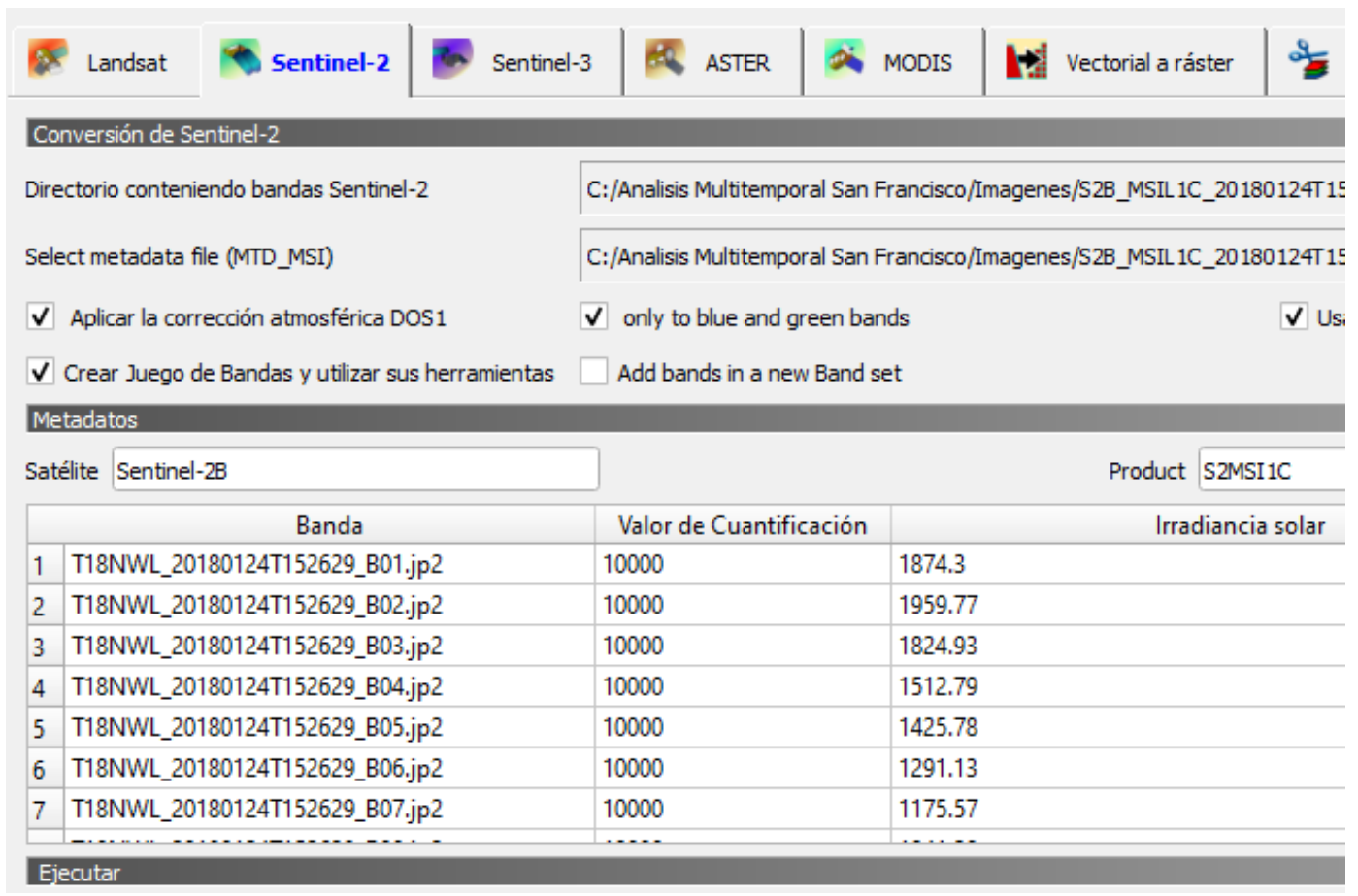

Fuente: QGis 3.8.1

La llustración 10 permite ver la configuración empleada en la corrección DOS1 para la imagen Sentinel 2, como ya se había mencionado en la explicación del Método de Chávez, se efectúa una conversión a radiancia antes de realizar este procedimiento además es la única corrección aplicada debido a que las imágenes Sentinel son distribuidas con los valores de reflectancia TOA ya escalados.

\subsubsection{Fragmentación del área de estudio}

Con el propósito de optimizar los procesos subsiguientes en el software de procesamiento, se precisó hacer la delimitación y recorte de la escena que contiene el área de estudio. Adicional a ello, se decidió incluir los municipios adyacentes bajo el criterio de presentar características similares en las coberturas del suelo. Lo anterior, con el fin de tener un área de trabajo más extensa (el área aproximada del municipio de San Francisco es de 118,20 Km²) que permitiera aumentar el número de muestras de entrenamiento, y así tener una clasificación más robusta.

La imagen se recortó eligiendo los siguientes municipios: La Vega, Nocaima, San Francisco, Sasaima y Supatá, constituyendo un área total de $592,98 \mathrm{Km}^{2}$. (llustración 11) 
llustración 11: Fragmentación del área de clasificación
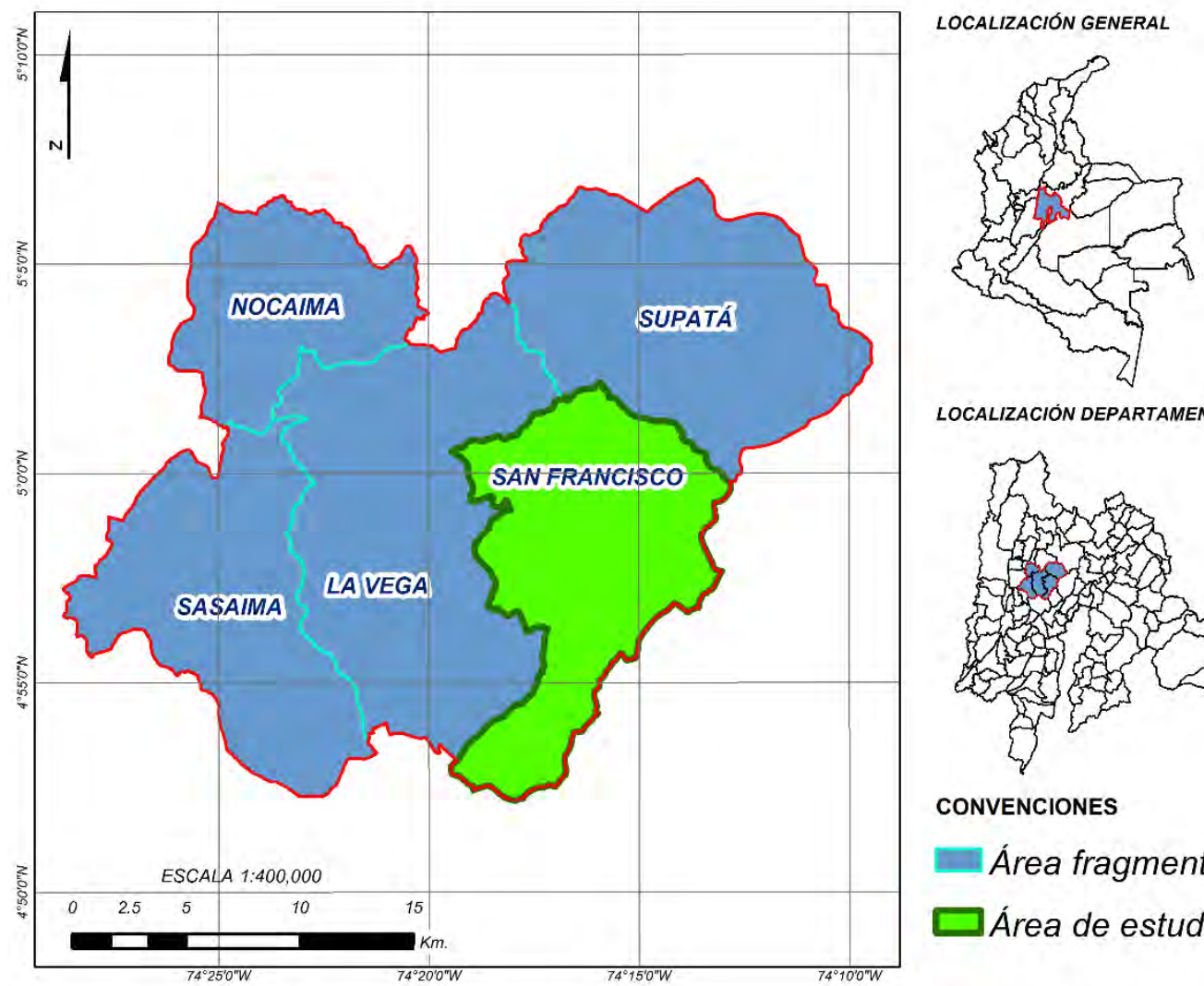

LOCALIZACIÓN DEPARTAMENTAL

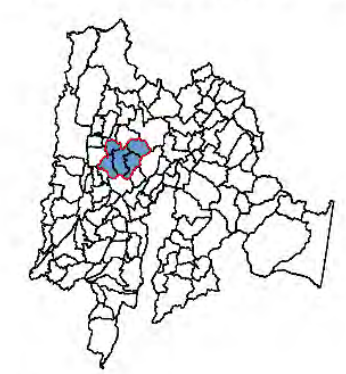

CONVENCIONES

Área fragmentada

$\square$ Área de estudio

Fuente: Elaboración de la Autora

\subsubsection{Definición de la Escala de trabajo}

Acorde con las características de los sensores utilizados se definió como escala de trabajo 1:100.000. Con base en lo descrito por el IDEAM et ál. (2008) para la metodología CLC, la unidad mínima cartografiable cuando se usan escenas de satélites Landsat está definida en 25 ha para el caso de coberturas y para elementos lineales como vías o ríos adicionalmente un ancho mínimo de $50 \mathrm{~m}$. Con la imagen Sentinel se trabajó de la misma manera, a pesar de que esta tiene una mejor resolución espacial, con el fin de obtener un nivel de detalle constante y que los resultados sean comparables. Por tanto, la resolución espacial es un elemento que está directamente relacionado con los datos raster utilizados.

\subsubsection{Combinación de Bandas}

Para un mejor análisis e interpretación visual se realizaron varias composiciones de las bandas obtenidas a partir del Layer stack, con el fin de observar e identificar las 
respectivas coberturas (Tabla 7 ). Estas combinaciones además soportaran la clasificación de las coberturas y usos en niveles superiores de acuerdo con el CLC. Las combinaciones más utilizadas fueron:

Tabla 7: Combinaciones de bandas utilizadas para Landsat y Sentinel-2MSI Respectivamente

\begin{tabular}{|c|c|}
\hline R-G-B & Descripción \\
\hline $4-3-2$ & $\begin{array}{l}\text { La vegetación aparece en tonos rojizos, las áreas urbanas son celestes } \\
\text { y los suelos varían de marrón oscuro hacia el claro en toda esta gama. } \\
\text { Ésta es una combinación muy popular y es útil para los estudios de } \\
\text { vegetación, monitoreo de drenajes, patrones de suelo y en varias fases } \\
\text { de crecimiento de los cultivos. Generalmente, los colores rojos } \\
\text { profundos indican hoja ancha y/o la vegetación más saludable mientras } \\
\text { los tonos de rojo más ligeras significan prados o áreas de vegetación } \\
\text { remanente escasa. }\end{array}$ \\
\hline $3-2-1$ & $\begin{array}{l}\text { Esta composición es denominada "color natural". Ya que las } \\
\text { características del terreno aparecen en los colores similares al sistema } \\
\text { de visión humano, la vegetación saludable es verde, campos } \\
\text { recientemente limpiados son muy claros en reflectancia, la vegetación } \\
\text { no saludable es marrón y amarilla, las vías son grises. Esta combinación } \\
\text { provee la mayor penetración del agua y sedimentos superficiales, así } \\
\text { como información batimétrica. Esta es también usada para estudios } \\
\text { urbanos. }\end{array}$ \\
\hline $4-5-3$ & $\begin{array}{l}\text { Ofrece una definición de los límites entre el suelo y agua. Muestra muy } \\
\text { bien las diferencias de humedad y es muy útil para el análisis de las } \\
\text { condiciones del suelo y la vegetación. Generalmente el suelo más } \\
\text { húmedo aparece más oscuro debido a la capacidad de absorción del } \\
\text { agua. }\end{array}$ \\
\hline $5-4-3$ & $\begin{array}{l}\text { La vegetación saludable es de un verde intenso y los suelos son de color } \\
\text { lila. Al usar la banda } 5 \text { la cual contiene la mayor información agrícola. }\end{array}$ \\
\hline
\end{tabular}




\begin{tabular}{|l|l|}
\hline R-G-B & \multicolumn{1}{|c|}{ Descripción } \\
\hline & $\begin{array}{l}\text { Esta combinación es muy útil para estudios de vegetación, y es } \\
\text { ampliamente usado en las áreas de manejo de madera. }\end{array}$ \\
\hline
\end{tabular}

Fuente: Franzosi (2010)

Ilustración 12: Imagen Sentinel-2 en Falso Color RGB 8, 4, 3.

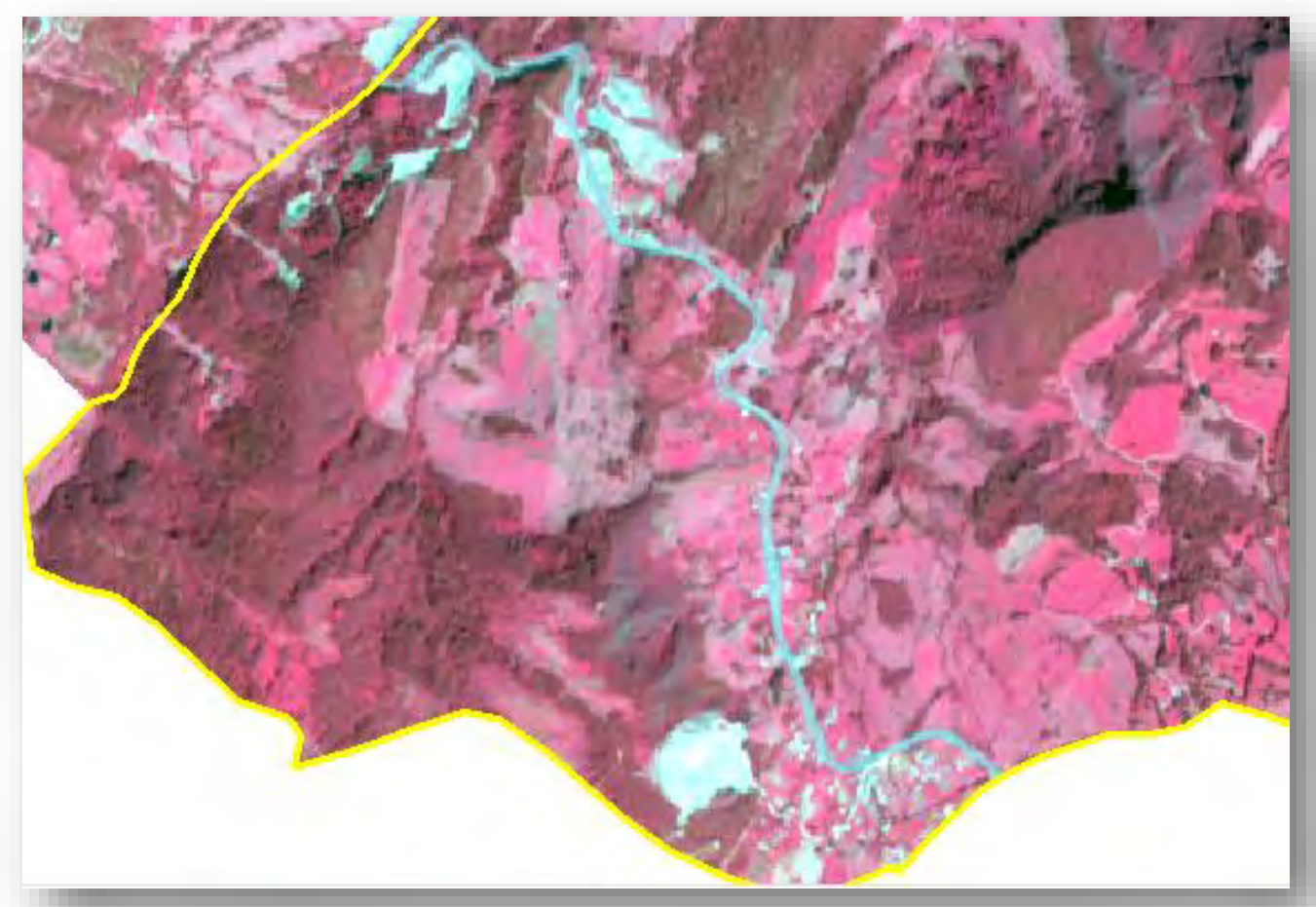

Fuente: Elaboración de la autora

La combinación de la llustración 12 refleja la sensibilidad a la clorofila, permitiendo que se observen variaciones de la vegetación, que aparecen en tonos rojo, (INEGI, 2010). También resalta en color más oscuro la vegetación vigorosa y más densa como la cobertura boscosa, en un color rosa las áreas vegetales menos densas y/o con temprano estado de crecimiento como pueden ser los pastos, en color blanco se presentan las áreas con escasa o nula vegetación por su alta reflectividad, aquí se encuentran los depósitos de extracción minera, las nubes y suelos desnudos, en tono gris a azul metálico se encuentran las vías de acceso y otras superficies urbanas. 


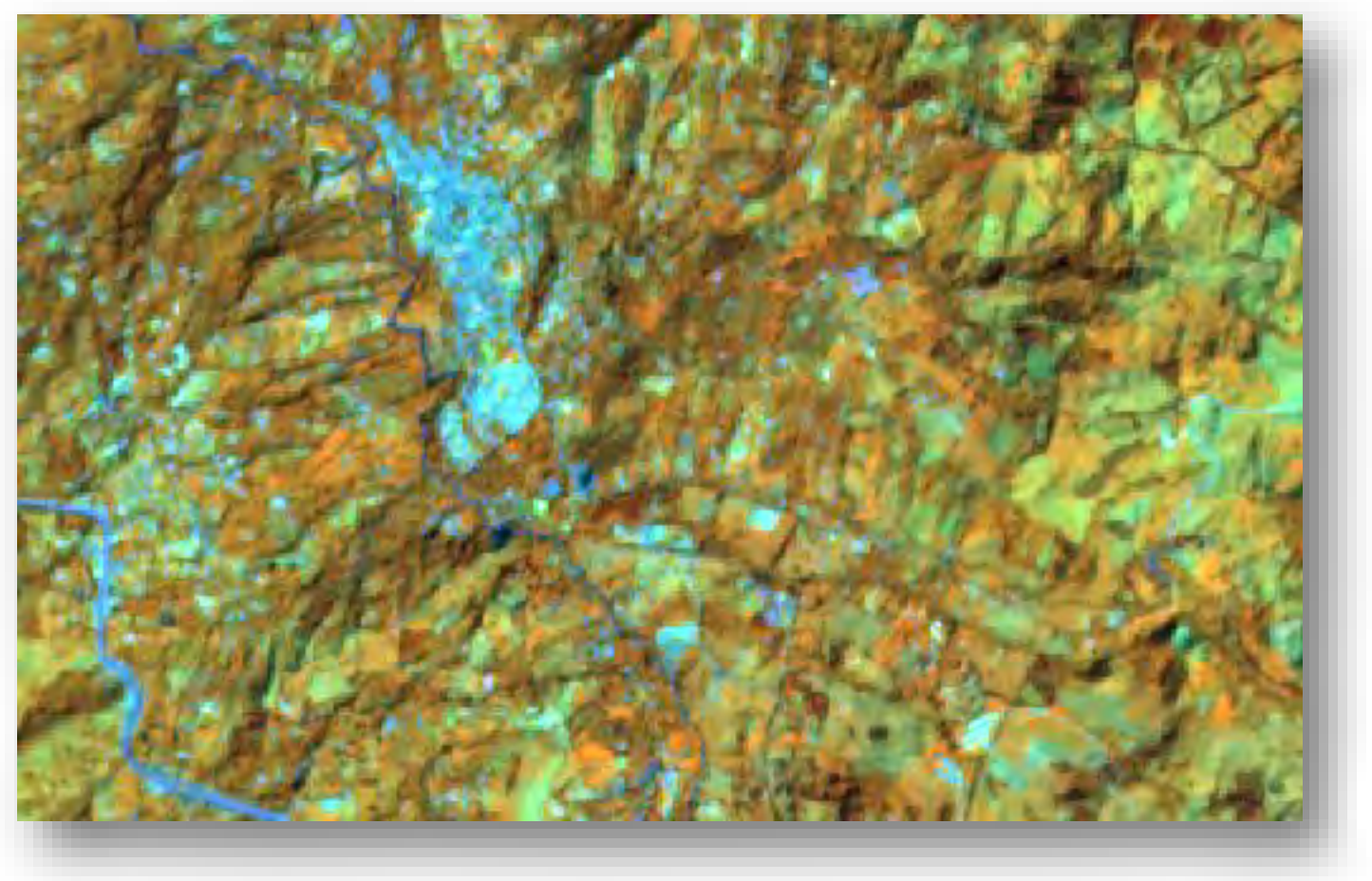

Fuente: Elaboración de la autora

En la llustración 13 se muestra el realce en tonos naranja de las áreas correspondientes a cultivos (Café, cítricos y plátano principalmente) o zonas de pastos plantados, en color café se destaca la cobertura de bosque denso y en azul claro los territorios artificializados. Es muy usada esta combinación debido a que resalta la humedad del suelo, haciendo más representativas las diferentes coberturas de la tierra, por lo general el suelo húmedo se observa más oscuro.

Las composiciones anteriores, en conjunto con los elementos pictórico morfológicos ayudaron a la identificación del primer nivel del CLC, también se recurrió al software ENVI 5.0 para hacer mejoramiento visual y espacial a través de la aplicación de realces y contrastes para poder hacer un mejor análisis visual de la imagen. Adicional a ello, fue importante el conocimiento previo del terreno y visitas de campo, siendo esto una actividad complementaria que incidió en el proceso de elección de las coberturas del CLC y la clasificación digital supervisada. 


\subsection{Procesamiento de la Información}

Una vez definida la escala de trabajo y combinación de bandas se procedió a determinar visualmente cada una de las coberturas existentes en el área de estudio. Lo anterior, fundamentado en el conocimiento previo del territorio, visitas de campo, el Esquema de Ordenamiento Territorial EOT, información de estudios anteriores, entre otros. C Estos se detallan en la Tabla 8: 
Tabla 8: Niveles CLC identificados en el municipio de San Francisco

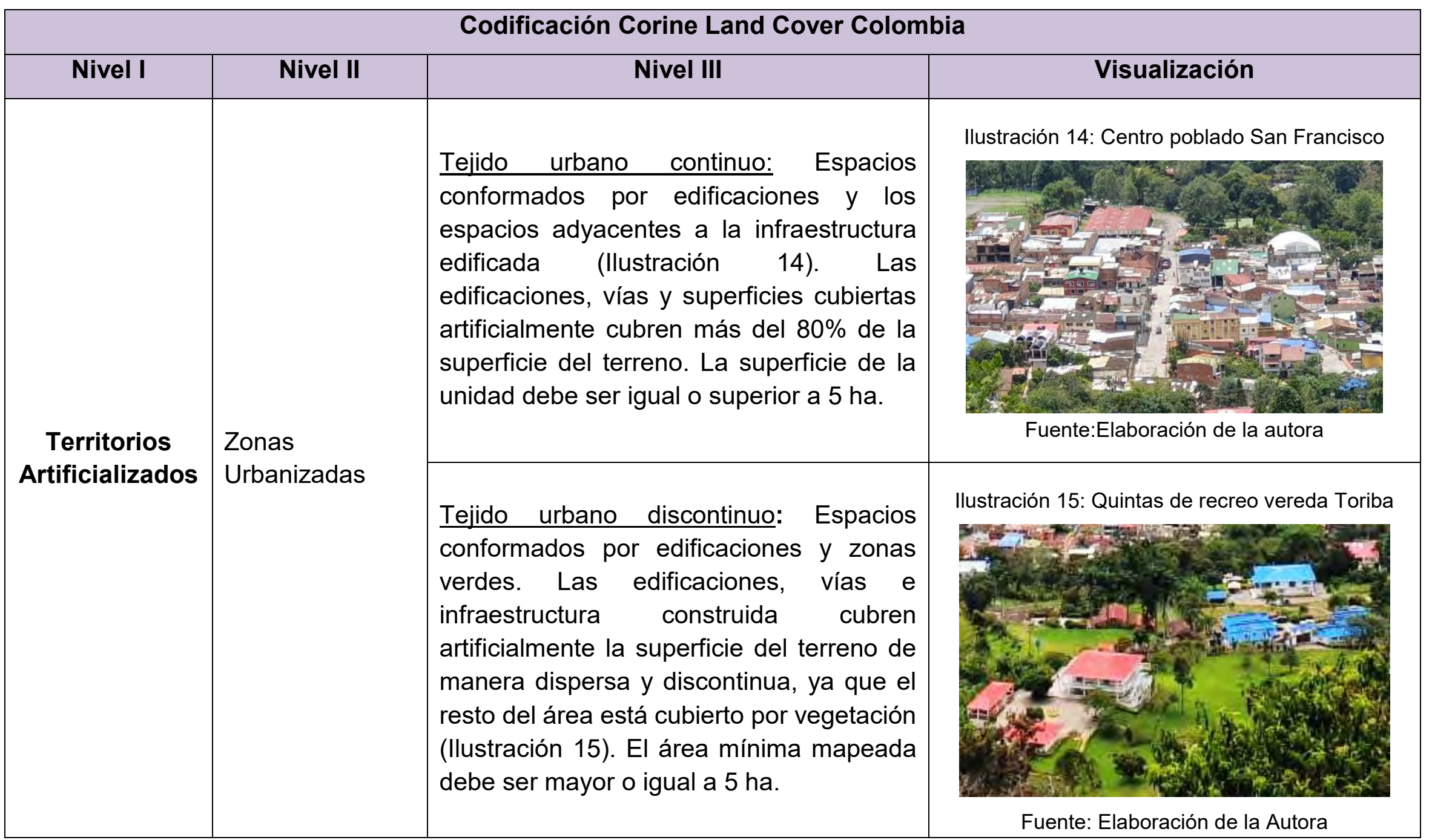




\begin{tabular}{|c|c|c|c|}
\hline \multicolumn{4}{|c|}{ Codificación Corine Land Cover Colombia } \\
\hline Nivel I & Nivel II & Nivel III & Visualización \\
\hline & $\begin{array}{l}\text { Zonas } \\
\text { Industriales o } \\
\text { comerciales y } \\
\text { redes de } \\
\text { comunicación }\end{array}$ & $\begin{array}{l}\text { Zonas industriales: Áreas recubiertas por } \\
\text { infraestructura artificial (terrenos } \\
\text { cimentados, alquitranados, asfaltados o } \\
\text { estabilizados), sin presencia de áreas } \\
\text { verdes dominantes, las cuales se utilizan } \\
\text { también para actividades comerciales o } \\
\text { industriales (Ilustración 16). El área mínima } \\
\text { mapeada debe ser mayor o igual a } 5 \text { ha. }\end{array}$ & $\begin{array}{l}\text { Ilustración 16: Inmunizadora de maderas San } \\
\text { Francisco }\end{array}$ \\
\hline
\end{tabular}




\begin{tabular}{|c|c|c|c|}
\hline \multicolumn{4}{|c|}{ Codificación Corine Land Cover Colombia } \\
\hline Nivel I & Nivel II & Nivel III & Visualización \\
\hline & $\begin{array}{l}\text { Zonas de } \\
\text { extracción } \\
\text { minera y } \\
\text { escombreras }\end{array}$ & $\begin{array}{l}\text { Zonas de extracción minera y } \\
\text { escombreras: Son áreas dedicadas a la } \\
\text { extracción de materiales minerales a cielo } \\
\text { abierto y/o espacios en los que se } \\
\text { depositan restos de construcción, residuos } \\
\text { urbanos, desechos industriales y material } \\
\text { estéril de minas (Ilustración 17). Se } \\
\text { incluyen áreas mayores o iguales a } 5 \text { ha. }\end{array}$ & $\begin{array}{l}\text { Ilustración 17: Cantera de Triturados Cerro } \\
\text { Cuadrado } \\
\text { Fuente: Johana Romero }\end{array}$ \\
\hline $\begin{array}{l}\text { Territorios } \\
\text { Agrícolas }\end{array}$ & Pastos & $\begin{array}{l}\text { Pastos limpios: Comprende las tierras } \\
\text { ocupadas por pastos limpios mayores o } \\
\text { iguales a } 25 \text { ha, es decir, que la realización } \\
\text { de prácticas de manejo (limpieza y/o } \\
\text { fertilización, etc.) utilizados impiden la } \\
\text { presencia o el desarrollo de otras } \\
\text { coberturas (llustración 18). }\end{array}$ & $\begin{array}{l}\text { Ilustración 18: Paisaje pastos limpios Alto del vino } \\
\text { Fuente: Mauricio Agudelo }\end{array}$ \\
\hline
\end{tabular}




\begin{tabular}{|c|c|c|c|}
\hline \multicolumn{4}{|c|}{ Codificación Corine Land Cover Colombia } \\
\hline Nivel I & Nivel II & Nivel III & Visualización \\
\hline & \multirow{2}{*}{$\begin{array}{l}\text { Áreas Agrícolas } \\
\text { Heterogéneas }\end{array}$} & $\begin{array}{l}\text { Mosaico de cultivos: Incluye las tierras } \\
\text { ocupadas con cultivos anuales, transitorios } \\
\text { o permanentes, en los cuales el tamaño de } \\
\text { las parcelas es muy pequeño (inferior a } 25 \\
\text { ha) y el patrón de distribución de los lotes } \\
\text { es demasiado intrincado para } \\
\text { representarlos cartográficamente de } \\
\text { manera individual (llustración 19). }\end{array}$ & $\begin{array}{l}\begin{array}{c}\text { Ilustración 19: Mosaico de Cultivos (Plátano, café, } \\
\text { cítricos) }\end{array} \\
\text { Fuente: Elaboración de la autora }\end{array}$ \\
\hline & & $\begin{array}{l}\text { Mosaico de cultivos y espacios naturales: } \\
\text { Comprende las tierras ocupadas por } \\
\text { cultivos y espacios naturales, en los cuales } \\
\text { el tamaño de las parcelas es muy pequeño, } \\
\text { inferior a } 25 \text { ha (Ilustración } 20 \text { ). } \\
\text { Los espacios naturales están conformados } \\
\text { por las áreas ocupadas por relictos de } \\
\text { bosque natural, arbustos y matorrales, } \\
\text { bosque ripario, pantanos y otras áreas no } \\
\text { intervenidas o poco transformadas. }\end{array}$ & $\begin{array}{l}\text { Ilustración 20: Mosaico de cultivos y espacios } \\
\text { naturales vereda San Miguel } \\
\text { F. } \\
\text { Fuente: Elaboración de la autora }\end{array}$ \\
\hline
\end{tabular}




\begin{tabular}{|c|c|c|c|}
\hline \multicolumn{4}{|c|}{ Codificación Corine Land Cover Colombia } \\
\hline Nivel I & Nivel II & Nivel III & Visualización \\
\hline & & $\begin{array}{l}\text { Mosaico de cultivos, pastos y espacios } \\
\text { naturales: Esta cobertura comprende las } \\
\text { superficies del territorio ocupadas } \\
\text { principalmente por coberturas de cultivos y } \\
\text { pastos en combinación con espacios } \\
\text { naturales importantes. En esta unidad, el } \\
\text { patrón de distribución de las zonas de } \\
\text { cultivos, pastos y espacios naturales no } \\
\text { puede ser representado individualmente, } \\
\text { con parcelas con tamaño menor a } 25 \text { ha ( } \\
\text { llustración 21). }\end{array}$ & $\begin{array}{l}\text { Ilustración 21: Mosaico de cultivos, pastos y } \\
\text { espacios naturales vereda San Miguel. }\end{array}$ \\
\hline $\begin{array}{c}\text { Bosques y } \\
\text { Áreas } \\
\text { Seminaturales }\end{array}$ & Bosques & $\begin{array}{l}\text { Bosque natural denso: Cobertura con área } \\
\text { mayor a } 25 \text { ha, constituida por una } \\
\text { comunidad vegetal dominada por } \\
\text { elementos típicamente arbóreos, los } \\
\text { cuales forman un estrato de copas (dosel) } \\
\text { más o menos continuo, con altura superior } \\
\text { a } 5 \text { metros (llustración } 22 \text { ). Estas } \\
\text { formaciones vegetales no han sido } \\
\text { intervenidas o su intervención ha sido } \\
\text { selectiva y no ha alterado su estructura } \\
\text { original y las características funcionales } \\
\text { (Oram, 1998). }\end{array}$ & $\begin{array}{l}\text { Ilustración 22: Bosque natural denso cercanías de } \\
\qquad \begin{array}{l}\text { La Laja } \\
\end{array}\end{array}$ \\
\hline
\end{tabular}




\begin{tabular}{|c|c|c|c|}
\hline \multicolumn{4}{|c|}{ Codificación Corine Land Cover Colombia } \\
\hline Nivel I & Nivel II & Nivel III & Visualización \\
\hline & & $\begin{array}{l}\text { Bosque natural fragmentado: Comprende } \\
\text { los territorios con áreas superiores a } 25 \text { ha, } \\
\text { cubiertos por bosques naturales con } \\
\text { intervención humana que mantienen su } \\
\text { estructura original. Se puede dar la } \\
\text { ocurrencia de áreas completamente } \\
\text { transformadas en el interior de la } \\
\text { cobertura, originando parches por la } \\
\text { presencia de otras coberturas como pasto, } \\
\text { cultivos y/o rastrojos que reemplazan la } \\
\text { cobertura original (llustración 23). }\end{array}$ & 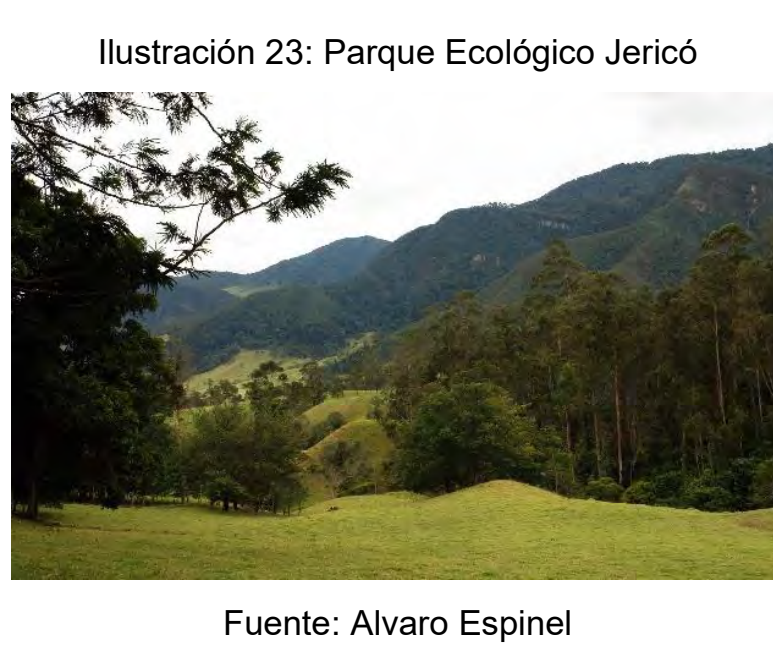 \\
\hline & & $\begin{array}{l}\text { Bosque ripario: Se refiere a las coberturas } \\
\text { constituidas por vegetación arbórea } \\
\text { ubicada en las márgenes de cursos de } \\
\text { agua permanentes o temporales, con } \\
\text { ancho de la franja mayor o igual a } 50 \\
\text { metros y área superior a } 25 \text { ha. El curso de } \\
\text { agua con ancho menor o igual a } 50 \text { metros. } \\
\text { Este tipo de cobertura está limitado por su } \\
\text { amplitud, ya que bordea los cursos de } \\
\text { agua y los drenajes naturales. Cuando la }\end{array}$ & $\begin{array}{l}\text { Ilustración 24: Bosque ripario quebrada El Muña } \\
\text { Fuente: Elaboración de la autora }\end{array}$ \\
\hline
\end{tabular}




\begin{tabular}{|c|c|c|c|}
\hline \multicolumn{4}{|c|}{ Codificación Corine Land Cover Colombia } \\
\hline Nivel I & Nivel II & Nivel III & Visualización \\
\hline & & $\begin{array}{l}\text { presencia de estas franjas de bosques } \\
\text { ocurre en zonas andinas son conocidas } \\
\text { como bosque ripario (llustración } 24 \text { ). }\end{array}$ & \\
\hline & & $\begin{array}{l}\text { Plantación Forestal: Son coberturas con } \\
\text { áreas mayores a } 25 \text { ha constituidas por } \\
\text { plantaciones de vegetación arbórea, } \\
\text { realizada por la intervención directa del } \\
\text { hombre con fines de manejo forestal. En } \\
\text { este proceso se constituyen rodales } \\
\text { forestales, establecidos mediante la } \\
\text { plantación y/o la siembra durante el } \\
\text { proceso de forestación o reforestación, } \\
\text { para la producción de madera o bienes no } \\
\text { madereros (llustración 25). } \\
\text { Las coberturas pueden estar formadas por } \\
\text { especies exóticas o nativas que son } \\
\text { sometidos a ordenación forestal } \\
\text { (protección, conservación, producción). }\end{array}$ & $\begin{array}{c}\text { Ilustración 25: Plantación Forestal de Eucalyptus } \\
\text { Fuente: Google } 2020\end{array}$ \\
\hline
\end{tabular}

Fuente: Elaboración de la autora a partir de la Metodología Corine Land Cover 
Posteriormente, se efectúo el proceso de clasificación supervisada de las imágenes satelitales. Para esta etapa se hizo una selección de muestras de entrenamiento representativas, con lo cual se captaron firmas espectrales homogéneas para cada uno de los niveles I del CLC presentes en el área de estudio.

Ilustración 26: Firmas Espectrales de la Clasificación Supervisada en imagen Landsat 4TM

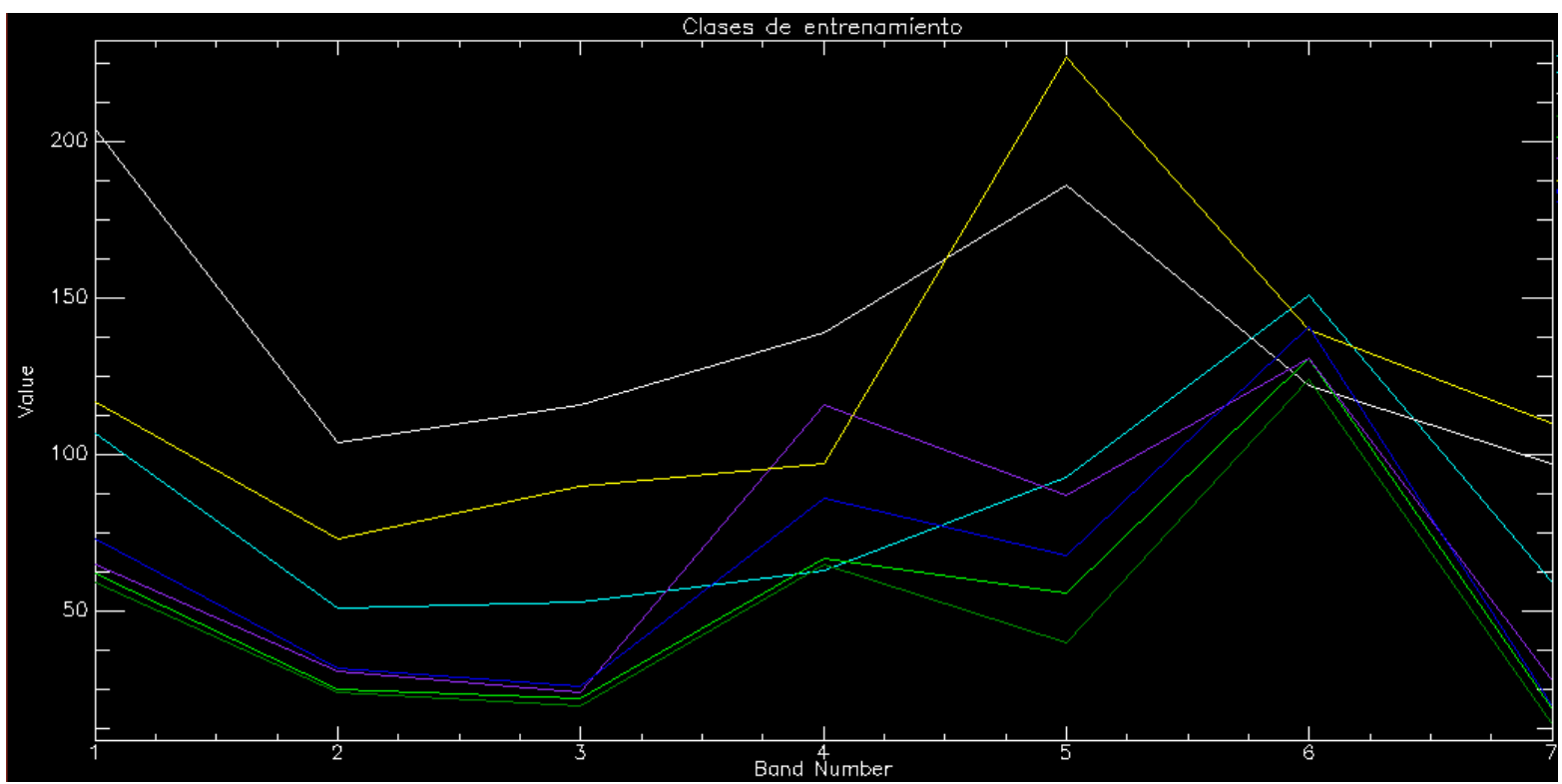

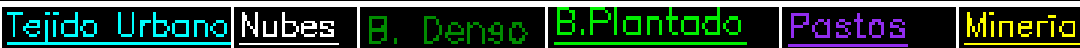

Fuente: ENVI 5.0

Es importante que entre las firmas espectrales exista separabilidad, dado que de esto depende que el software haga una correcta clasificación, y se minimice el riesgo de error en el momento de elegir la pertenencia de los niveles digitales a una u otra clase; para su evaluación se pueden utilizar métodos gráficos (Ilustración 26) y/o métodos numéricos que permiten su distinción.

Las características espectrales tuvieron como finalidad preparar el algoritmo de clasificación para calcular los parámetros estadísticos de cada banda. De esta manera, se evaluó cada pixel de la imagen, se comparó y asignó a una respectiva clase mediante una regla de decisión del software.

El algoritmo utilizado para esta clasificación fue el de máxima probabilidad Maximun Likelihood del software ENVI5.0, este tiene en cuenta las varianzas y covarianzas de las firmas espectrales cuando asigna cada celda a una de las clases representadas en el archivo de firma. Según Reuter (2002), si se asume que la 
distribución de una muestra de clases es normal, una clase puede estar caracterizada por el vector del valor medio y la matriz de covarianza. Dadas estas dos características para cada valor de celda, se calcula la probabilidad estadística para cada clase a fin de determinar la pertenencia de las celdas a la clase. El clasificador de Máxima Probabilidad es el más complejo y el que demanda mayor volumen de cálculo. Sin embargo, es el más empleado en teledetección, por su robustez y por ajustarse con más rigor a la disposición original de los datos.

Los resultados obtenidos son dos imágenes clasificadas en formato ráster, una para cada época.

\subsection{Validación de los resultados}

Para realizar la validación de resultados Ingeoexpert (2018) señala al respecto:

El análisis de precisión es un paso fundamental durante el proceso de clasificación digital. La calidad hace referencia a la totalidad de las características de un producto que tienen que ver con sus aptitudes para satisfacer las necesidades explícitas e implícitas. En cartografía, se considera el control topológico y temático de la cartografía generada.

Por ende, se hizo una comprobación y verificación de los resultados obtenidos mediante dos métodos distintos, uno para cada periodo evaluado.

\subsubsection{Validación clasificación 1988 Landsat 4TM}

Para este proceso se utilizó el estudio cartográfico realizado por la Gobernación de Cundinamarca (2002), denominado mapa de uso actual y cobertura vegetal de los suelos del departamento de Cundinamarca a escala 1:25.000 para el año 1993, con el cual se crearon instrumentos actualizados de planificación que sirvieran de soporte a los planes, programas y proyectos agropecuarios y de ordenamientos territorial regional y municipal de la época.

Tomando como insumo principal el mapa producto del estudio, se procedió a hacer la digitalización de la zona de interés en el software ArcGIS 10.5 con el propósito de confrontar estos usos de suelo y la clasificación resultante para la escena del año 1988 (cabe resaltar que, únicamente se toma el área del municipio puesto que es el objetivo de este trabajo). Para lo anterior, se hizo 
necesaria la homologación y/o recategorización de los usos contemplados en dicho estudio y los descritos en el CLC (Tabla 9), dado que para ese momento esta estandarización no existía aún. De acuerdo con lo anterior se tiene:

Tabla 9: Homologación de las coberturas

\begin{tabular}{|l|l|}
\hline CARTOGRAFÍA 1:25.000 & CORINE LAND COVER \\
\hline Zonas Urbanas e Infraestructura & Tejido Urbano Continuo \\
\hline Zonas Minera y Canteras & $\begin{array}{l}\text { Zonas de extracción minera y } \\
\text { escombreras }\end{array}$ \\
\hline Pastos Manejados/ Pasto Natural & Pastos Limpios \\
\hline Cultivos con malezas & $\begin{array}{l}\text { Mosaico de cultivos y espacios } \\
\text { naturales }\end{array}$ \\
\hline Bosque Natural & Bosque natural denso \\
\hline Bosque Secundario & Bosque natural fragmentado \\
\hline Bosque Plantado & Plantación Forestal \\
\hline $\begin{array}{l}\text { Café, Caña Panelera, Plátano, } \\
\text { Cítricos. }\end{array}$ & Mosaico de Cultivos \\
\hline
\end{tabular}

Fuente: Elaboración de la Autora

Una vez obtenida la estandarización de las coberturas, se procedió a hacer el cruce de información con el uso de la herramienta de geoprocesamiento Intersect de ArcGIS 10.5. 
Ilustración 27: Resultado Validación de clasificación 1988
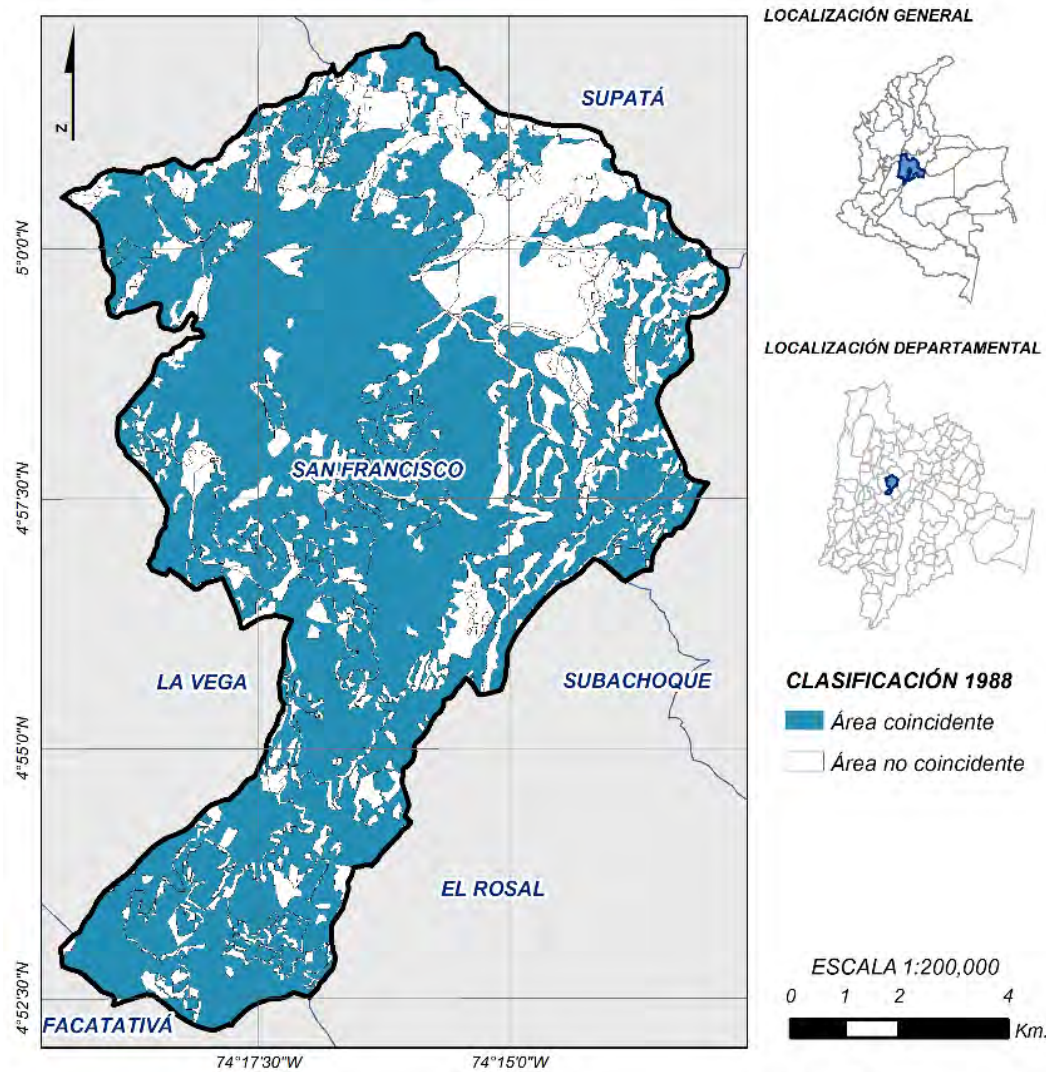

Fuente: Elaboración de la autora

Como se puede observar en la llustración 27 , se resaltan en color azul todas las áreas de uso de suelo coincidentes y en color blanco las que no coincidieron. El porcentaje de coincidencia fue del $79 \%$ del área total del municipio, exceptuando las áreas sin información debido a la presencia de nubes en el estudio hecho por la Gobernación de Cundinamarca en 2002 (Ilustración 28).

Tabla 10: Validación de la Clasificación

\begin{tabular}{|l|c|}
\hline Descripción & Área ha \\
\hline Área Municipal & 11.820 \\
\hline Área Sin Información (Estudio) & 1.340 \\
\hline Área neta municipal para comparar & 10.480 \\
\hline Coberturas coincidentes & 8.291 \\
\hline Coberturas no coincidentes & 2.189 \\
\hline$\%$ de acierto & $\mathbf{7 9 \%}$ \\
\hline
\end{tabular}

Fuente: Elaboración de la autora 
Ilustración 28: Áreas no comparables por presencia de nubes

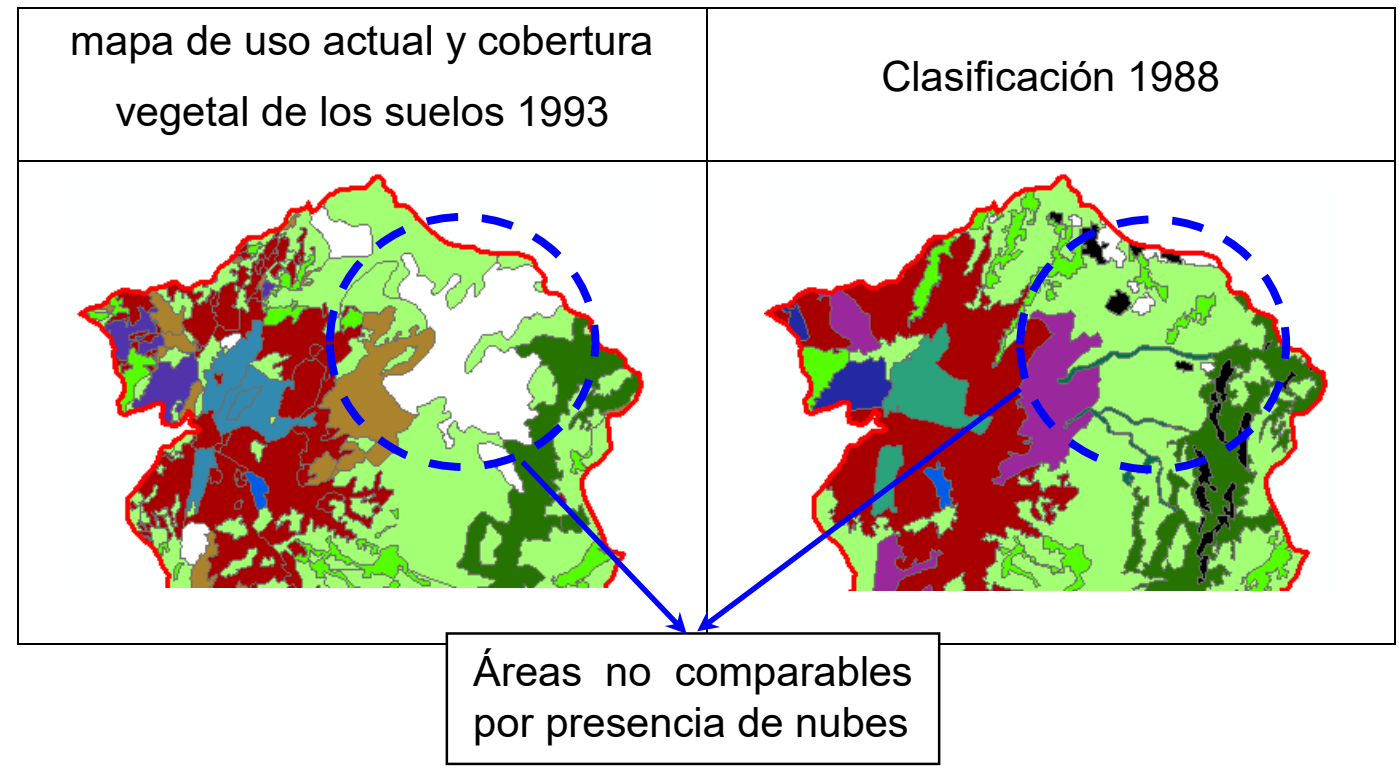

Fuente: Elaboración de la autora

Las diferencias encontradas en el $21 \%$ no coincidente, se explica en parte por la existencia de sombras en la clasificación de la escena y la no inclusión de la clase bosque ripario en el estudio dispuesto por la Gobernación de Cundinamarca en 2002 (Ilustración 29).

Ilustración 29: Áreas no coincidentes

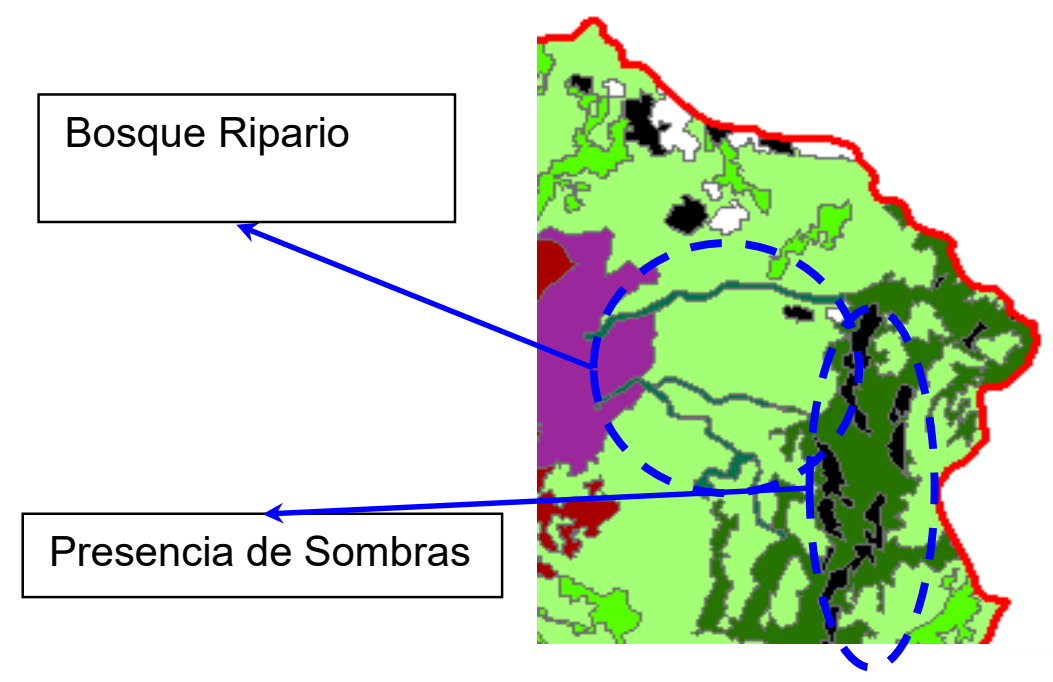

Fuente: Elaboración de la autora 


\subsubsection{Validación clasificación 2018 Sentinel-2 MSI}

De acuerdo con lo mencionado por Jensen (1986, citado en Niclós Corts et ál., 2010) para estimar la precisión de una clasificación se ha de calcular la matriz de confusión, cuyo objetivo es comparar los resultados de la clasificación y áreas verdad terreno, de este modo identificar el número total de pixeles de referencia que siendo de un tipo dado han sido asignados a cada una de las clases. A partir de la matriz de confusión o de error, se estiman los siguientes parámetros que determinan su precisión:

- Precisión global: Cuantifica el número de pixeles correctamente clasificados.

- Precisión del productor: Indica la probabilidad de que un píxel de una determinada clase esté correctamente clasificado.

- Precisión del usuario: Enseña la probabilidad de que un píxel clasificado como una clase determinada corresponda a dicha clase.

- Coeficiente Kappa: Calcula la correspondencia entre la imagen clasificada y la realidad según la exactitud de la clasificación y eliminando el factor azar (p. 5).

Los parámetros descritos anteriormente, de acuerdo con Niclós Corts et ál. (2010) permiten evaluar la bondad del método de clasificación, usando las regiones de interés seleccionadas para cada clase en el proceso de entrenamiento, y la precisión de la clasificación obtenida, utilizando áreas verdad terreno de validación no usadas como áreas de entrenamiento.

En muchas ocasiones, el área de exploración para la toma de muestras no es totalmente accesible, por lo cual se debe realizar siguiendo las rutas o caminos existentes (Boca \& Rodríguez, 2012). En este caso, el registro de las áreas verdad terreno, consistió en verificar a través de observación directa la cobertura que corresponde a cada punto de muestreo, estos sitios van ligados a la red vial primordialmente y a terrenos de fácil acceso dentro de la zona de estudio.

Esta labor estuvo acompañada de un protocolo de trabajo adecuado y un diseño de muestreo previo, el cual consistió en la creación de un mapa en la aplicación Google Maps (llustración 30), que contiene el listado de 40 puntos de exploración debidamente georreferenciados en coordenadas WGS84. Está aplicación concedió al interprete las indicaciones para desplazarse hasta cada uno de los puntos definidos para la verificación en campo y permitió la toma de 
fotografías y anotación de observaciones pertinentes para cada uno de ellos, almacenando toda la información recopilada de manera instantánea en el Drive, siendo de gran utilidad para este procedimiento (Ilustración 31).

Ilustración 30: Puntos de Muestreo Verdad Terreno

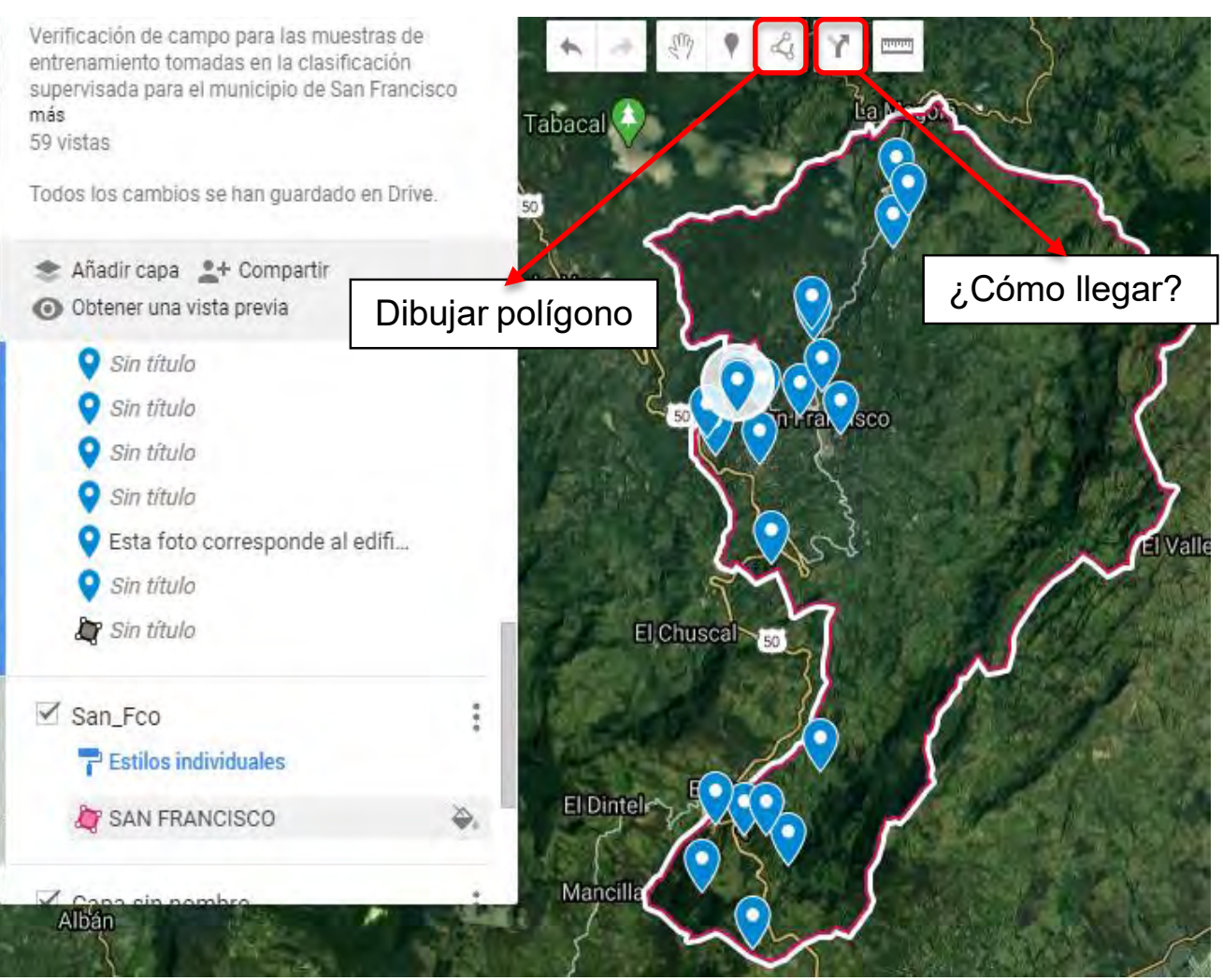

Fuente: Elaboración de la autora a partir de Google Maps 
Ilustración 31: Almacenamiento de Información Puntos de Muestreo

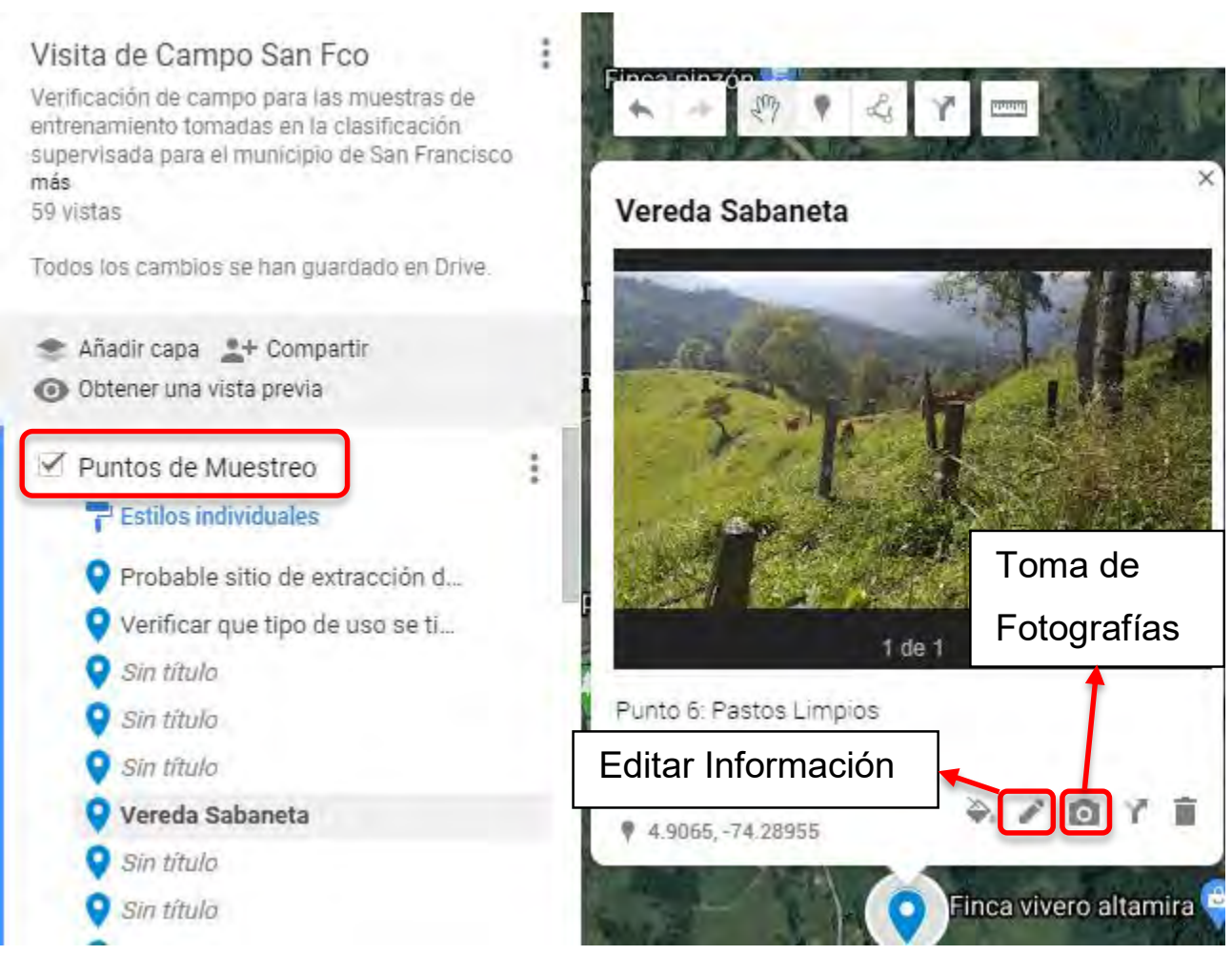

Fuente: Elaboración de la autora a partir de Google Maps

Los puntos de muestreo se sobrepusieron en el raster de coberturas del suelo, producto de la clasificación supervisada que se hizo para el año 2018, se seleccionaron polígonos de control sobre la imagen de cada una de las clases, para evaluar los resultados de la clasificación.

La matriz de confusión se generó a partir de los pixeles que se tomaron como muestras verdad terreno. Del conjunto de pixeles muestreados, la matriz compara los valores de las filas que representan las clases obtenidas tras la clasificación versus los valores de las columnas que constituyen las muestras verdad terreno. De esta manera, en la diagonal de la matriz se encuentran los aciertos, es decir, aquellos pixeles que coincidieron en la clasificación y los muestreados en terreno. Los residuales de las filas son los errores por omisión, mientras que los residuales de las columnas son los de comisión. Es decir que, los errores por omisión son aquellos pixeles que el usuario incluyó en una clase determinada y el clasificador lo encontró perteneciente a otra. Por el contrario, los errores por comisión son aquellos pixeles que el clasificador encuentra 
pertenecientes a una clase y que no fue definido de la misma manera por el usuario.

En la llustración 32 se muestra el reporte del software ENVI 5.0 con los datos obtenidos de la validación:

Ilustración 32: Matriz de Confusión o de error.

Confusion Matrix: C: \Analisis Multitemporal San Francisco $\backslash 2018^{\backslash}$

Overall Accuracy $=(930 / 988) \quad 94.1296 \%$

Kappa Coefficient $=0.9222$

Ground Truth (Pixels)

Class VT. T. Aritific VT. Bosques VT. Pastos Li VT. Sombras VT. Cultivos Unclassified

T. Artificial

$\begin{array}{rr}0 & 0 \\ 113 & 1 \\ 0 & 147 \\ 0 & 0 \\ 0 & 0 \\ 0 & 1 \\ 113 & 149\end{array}$

0
18
0
296
0
0
314

VT. Sombras VT. Cultivos

Bosques

Pastos Limpio

Sombras [Blac

Mosaico Culti

Total

149

314

$\begin{array}{rr}0 & 0 \\ 37 & 0 \\ 0 & 1 \\ 295 & 0 \\ 0 & 79 \\ 332 & 80\end{array}$

Class

Unclassified

T. Artificial

Bosques

Pastos Limpio

Sombras [Blac

Mosaico Culti

Total
Ground Truth (Pixels)

Total

$$
\begin{array}{r}
0 \\
132 \\
184 \\
297 \\
295 \\
80 \\
988
\end{array}
$$

\begin{tabular}{rrrrrr}
\multicolumn{7}{c}{ Ground Truth (Percent) } & & & \\
Class VT.T. Artific VT. Bosques & VT. Pastos Li & VT. Sombras VT. Cultivos \\
Unclassified & 0.00 & 0.00 & 0.00 & 0.00 & 0.00 \\
T. Artificial & 100.00 & 0.67 & 5.73 & 0.00 & 0.00 \\
Bosques & 0.00 & 98.66 & 0.00 & 11.14 & 0.00 \\
Pastos Limpio & 0.00 & 0.00 & 94.27 & 0.00 & 1.25 \\
Sombras [Blac & 0.00 & 0.00 & 0.00 & 88.86 & 0.00 \\
Mosaico Culti & 0.00 & 0.67 & 0.00 & 0.00 & 98.75 \\
Total & 100.00 & 100.00 & 100.00 & 100.00 & 100.00
\end{tabular}

Fuente: ENVI 5.0

Conforme lo menciona Chuvieco (1995), "un valor de K próximo a 1 indica un acuerdo pleno entre la realidad y el mapa, mientras un valor cercano a 0 sugiere que el acuerdo observado es puramente debido al azar" (p. 394). El coeficiente Kappa (K) obtenido de la matriz de confusión fue de 0.92, indicando un óptimo porcentaje de correspondencia entre la clasificación y la realidad de terreno. 


\subsection{Generación de Información - Generalización}

Una vez obtenido y validado el insumo en formato ráster de la clasificación supervisada, se exportó a formato vector e inmediatamente se editó.

Las imágenes clasificadas normalmente presentan falta de continuidad y coherencia espacial de las clases. En la escena clasificada quedaron una serie de píxeles aislados, los cuales no representaban un área significativa, por tanto, se optó por generalizar o editar el producto de la clasificación, con la finalidad de que las clases predominantes absorban estos píxeles. Para ello, se tuvo en cuenta la escala de trabajo 1:100.000. Dicho de otro modo, durante la edición se aplicaron reglas básicas de generalización que permitieron decidir sobre polígonos que no cumplían el criterio de área mínima de mapeo establecida, es decir, mayor o igual a 25 hectáreas (categorías 2 a 5 del nivel 1 de la nomenclatura), mayor o igual a 5 hectáreas (categorías 1 del nivel 1 de la nomenclatura) y ancho mayor a 50 metros. Esas pautas se acogieron del sistema CLC adoptado para Colombia.

Adicionalmente el Instituto de Hidrología, Meteorología y Estudios Ambientales (IDEAM) señala respecto a las reglas de generalización su importancia en el proceso de interpretación IDEAM et ál. (2008), y precisa lo siguiente:

Cuando se presentan estos polígonos pequeños puede ocurrir que ellos se encuentren rodeados por una unidad mayor en forma individual o que hagan parte de un grupo de unidades que no satisfagan los criterios. Para incorporar estas coberturas de área reducida en las coberturas vecinas que sí cumplen el tamaño mínimo, se aplicó un conjunto de reglas de generalización que permiten definir qué acción se debe emplear en los diferentes casos que se presentan (pág. 65).

Dado que, la generalización es fundamental en el proceso de interpretación, a continuación se describen algunas de las reglas más utilizadas y sus respectivos ejemplos:

Cuando la unidad, en este caso denominada 112, sea menos a 5 ha y se encuentre rodeada por una sola unidad de tamaño mayor o igual a 25 ha, la unidad pequeña se adiciona a la unidad de mayor tamaño, esta última unidad se representada en la llustración 33 con el número 211. 
Ilustración 33: Agregación de un polígono pequeño ubicado dentro de un polígono grande -112 ( $<5$ ha) y 211 ( $\geq 25$ ha)

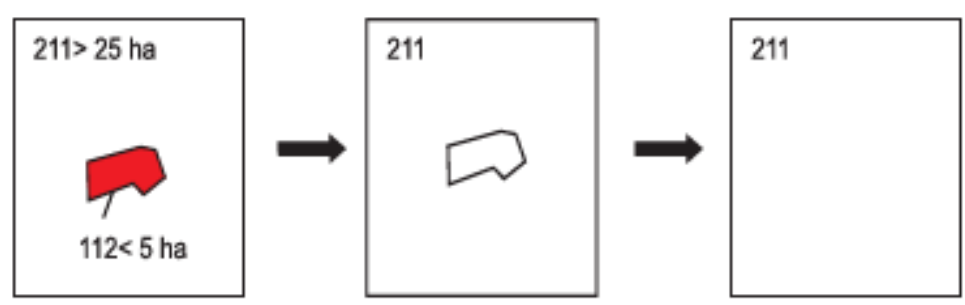

Fuente: IDEAM et ál. (2008)

Para áreas pequeñas de centros poblados, menores a 5 ha, se deben agrupar si la distancia entre las unidades es menor a 300 metros de manera que se obtenga una unidad, que de acuerdo a la llustración 34 se llamará 121, mayor a 25 ha. Entonces, las unidades menores a 5 ha se agrupan según las líneas de las vías con el propósito de formar una unidad $\geq 25$ ha.

Ilustración 34 Generalización para centros poblados.
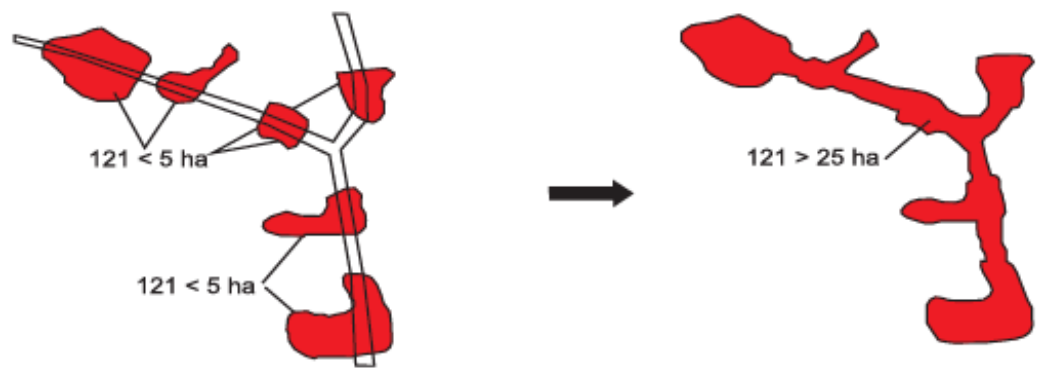

Fuente: IDEAM et ál. (2008)

- Cuando se presenta alguna unidad grande de bosque natural, para este ejemplo se denominara 311 , la presencia de varios cultivos aislados de tamaño menor a 25 ha podría constituir una clase, por consiguiente es necesario considerar la densidad de cultivos. Para porcentajes inferiores al $5 \%$ se debe mantener la clasificación de bosque natural (311); para el intervalo de $5 \%$ a $30 \%$ se delimita como bosque fragmentado o unidad 312 (llustración 35) y para una densidad de cultivos que este entre $30 \%$ y $70 \%$ se delimitara como zona de mosaicos 243 ó 244 según lo presentado en la llustración 36. 
Ilustración 35: Delimitación de bosque fragmentado en zona de bosque denso
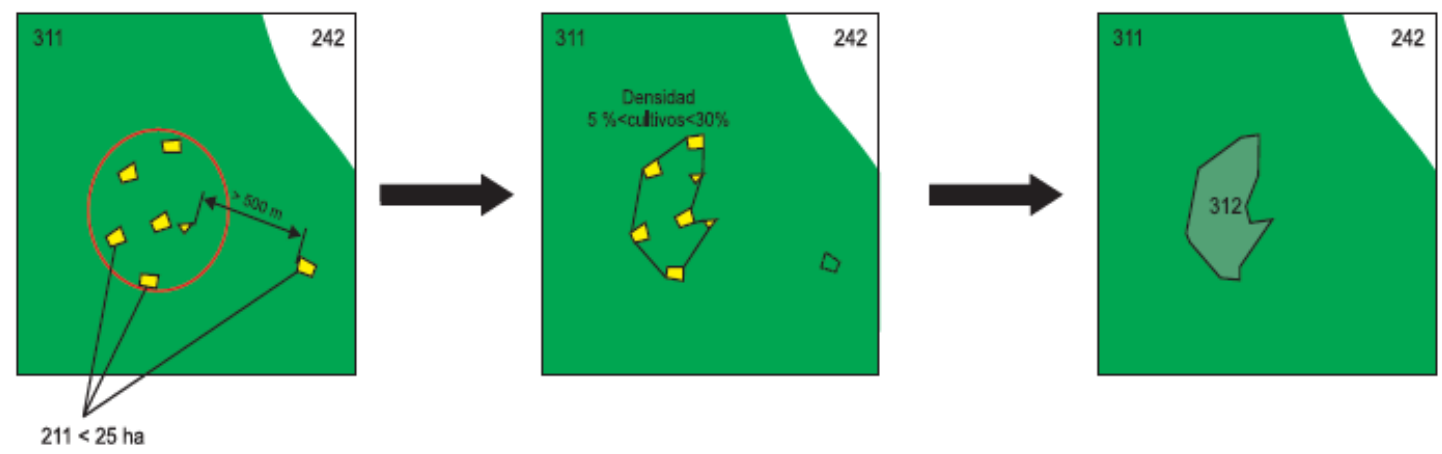

Fuente: IDEAM et ál. (2008)

Ilustración 36: Delimitación zona de mosaico en zona de bosque denso.
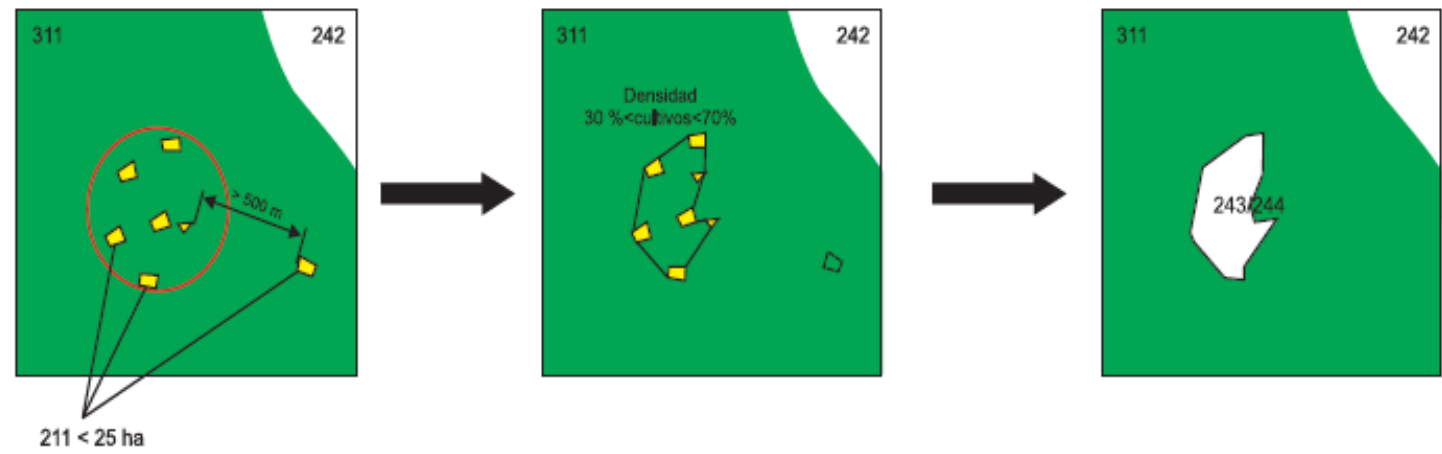

Fuente: IDEAM et ál. (2008)

- El mosaico de cultivos, pastos y espacios naturales o seminaturales resulta de la composición entre tierras agrícolas con presencia de pequeñas áreas naturales o seminaturales, incluyendo cuerpos de agua y humedales, con áreas menores a 25 ha.

Ilustración 37: Delimitación de espacios naturales menores a 25 ha (311), ubicado dentro de un polígono de cultivos ( $211 \geq 25$ ha).
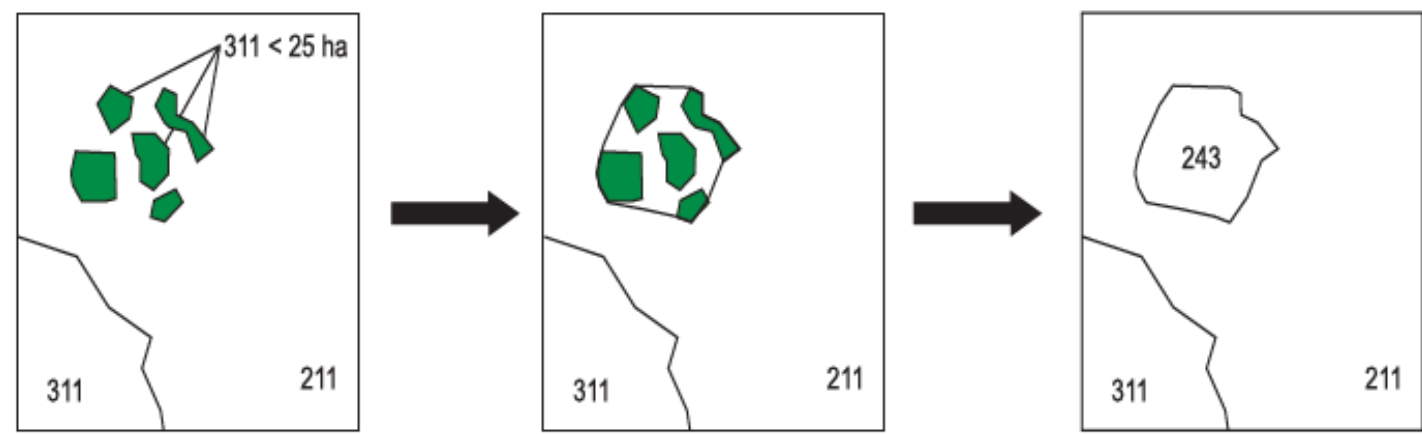

Fuente: IDEAM et ál. (2008) 


\subsection{Uso de la Información}

Finalmente, con el producto de la generalización se obtuvieron los mapas de coberturas y usos de la tierra existentes para cada época analizada 1988 (Anexo 1) y 2018 (Anexo 2), su disposición dentro del municipio y la cuantificación de las áreas. (Tabla 11)

Tabla 11: Cobertura de la tierra CLC identificadas en el municipio de San Francisco (Cund.) Periodos 1988 / 2018

\begin{tabular}{|c|c|c|c|c|c|c|}
\hline \multicolumn{3}{|c|}{ Codificación Corine Land Cover Colombia } & \multicolumn{2}{|c|}{1988} & \multicolumn{2}{|c|}{2018} \\
\hline Nivel I & Nivel II & Nivel III & $\begin{array}{c}\text { Área } \\
\text { ha }\end{array}$ & $\%$ & $\begin{array}{c}\text { Área } \\
\text { ha }\end{array}$ & $\%$ \\
\hline \multirow{4}{*}{$\begin{array}{l}\text { Territorios } \\
\text { Artificializados }\end{array}$} & \multirow{2}{*}{$\begin{array}{l}\text { Zonas } \\
\text { Urbanizadas }\end{array}$} & $\begin{array}{l}\text { Tejido urbano } \\
\text { continuo }\end{array}$ & 27,2 & 0,2 & 133,8 & 1,1 \\
\hline & & $\begin{array}{l}\text { Tejido urbano } \\
\text { discontinuo }\end{array}$ & 0,0 & 0,0 & 281,7 & 2,4 \\
\hline & $\begin{array}{l}\text { Zonas } \\
\text { Industriales o } \\
\text { comerciales y } \\
\text { redes de } \\
\text { comunicación }\end{array}$ & $\begin{array}{l}\text { Zonas } \\
\text { industriales }\end{array}$ & 0,0 & 0,0 & 8,4 & 0,1 \\
\hline & $\begin{array}{l}\text { Zonas de } \\
\text { extracción } \\
\text { minera y } \\
\text { escombreras }\end{array}$ & $\begin{array}{l}\text { Zonas de } \\
\text { extracción } \\
\text { minera y } \\
\text { escombreras }\end{array}$ & 4,3 & 0,0 & 18,1 & 0,2 \\
\hline \multicolumn{3}{|r|}{ Subtotal } & 31,5 & 0,3 & 442,0 & 3,7 \\
\hline \multirow{4}{*}{$\begin{array}{l}\text { Territorios } \\
\text { Agrícolas }\end{array}$} & Pastos & Pastos limpios & 5089,4 & 43,1 & 5940,8 & 50,3 \\
\hline & \multirow{3}{*}{$\begin{array}{l}\text { Áreas Agrícolas } \\
\text { Heterogéneas }\end{array}$} & $\begin{array}{l}\text { Mosaico de } \\
\text { cultivos }\end{array}$ & 3246,7 & 27,5 & 996,9 & 8,4 \\
\hline & & $\begin{array}{lr}\text { Mosaico } & \text { de } \\
\text { cultivos } & y \\
\text { espacios } & \\
\text { naturales } & \end{array}$ & 202,1 & 1,7 & 420,0 & 3,6 \\
\hline & & $\begin{array}{l}\text { Mosaico de } \\
\text { cultivos, }\end{array}$ & 0,0 & 0,0 & 394,1 & 3,3 \\
\hline
\end{tabular}




\begin{tabular}{|c|c|c|c|c|c|c|}
\hline \multicolumn{3}{|c|}{ Codificación Corine Land Cover Colombia } & \multicolumn{2}{|c|}{1988} & \multicolumn{2}{|c|}{2018} \\
\hline Nivel I & Nivel II & Nivel III & $\begin{array}{c}\text { Área } \\
\text { ha }\end{array}$ & $\%$ & $\begin{array}{c}\text { Área } \\
\text { ha }\end{array}$ & $\%$ \\
\hline & & $\begin{array}{ll}\text { pastos } & y \\
\text { espacios } & \\
\text { naturales } & \end{array}$ & & & & \\
\hline \multicolumn{3}{|r|}{ Subtotal } & 8538,3 & 72,2 & 7751,9 & 65,6 \\
\hline \multirow{4}{*}{$\begin{array}{l}\text { Bosques y } \\
\text { Áreas } \\
\text { Seminaturales }\end{array}$} & \multirow{4}{*}{ Bosques } & $\begin{array}{l}\text { Bosque natural } \\
\text { denso }\end{array}$ & 1703,0 & 14,4 & 1861,1 & 15,7 \\
\hline & & $\begin{array}{l}\text { Bosque natural } \\
\text { fragmentado }\end{array}$ & 663,8 & 5,6 & 1067,8 & 9,0 \\
\hline & & Bosque ripario & 84,3 & 0,7 & 217,1 & 1,8 \\
\hline & & $\begin{array}{l}\text { Plantación } \\
\text { Forestal }\end{array}$ & 443,7 & 3,8 & 437,0 & 3,7 \\
\hline \multicolumn{3}{|r|}{ Subtotal } & 2894,7 & 24,5 & 3582,9 & 30,3 \\
\hline \multicolumn{2}{|l|}{ Sin Clasificar } & $\begin{array}{l}\text { Nubes/ } \\
\text { sombras }\end{array}$ & 355,6 & 3,0 & 43,2 & 0,4 \\
\hline \multicolumn{3}{|r|}{ Total } & 11820 & 100 & 11820 & 100 \\
\hline
\end{tabular}

Fuente: Elaboración de la autora

Para determinar los cambios de uso del suelo, se planteó una matriz de tabulación cruzada entre los mapas de coberturas de las fechas estudiadas. En esta matriz las filas representan las categorías del año 1988 y las columnas las categorías del año 2018; cada cobertura se renombró con un número entero de 1 - 10 y de $100-1000$ para cada año respectivamente, por tanto, la matriz se compone de la suma de los números que se asignaron a cada cobertura (Tabla 12). Las áreas que no fueron objeto de cambios, es decir, las zonas que persisten entre el periodo de tiempo son representadas con los valores que se muestran en la diagonal de la tabla, y los valores fuera de esta corresponden a los cambios ocurridos entre coberturas de suelo a lo largo del tiempo. 
Tabla 12: Planteamiento de la Matriz de Tabulación Cruzada

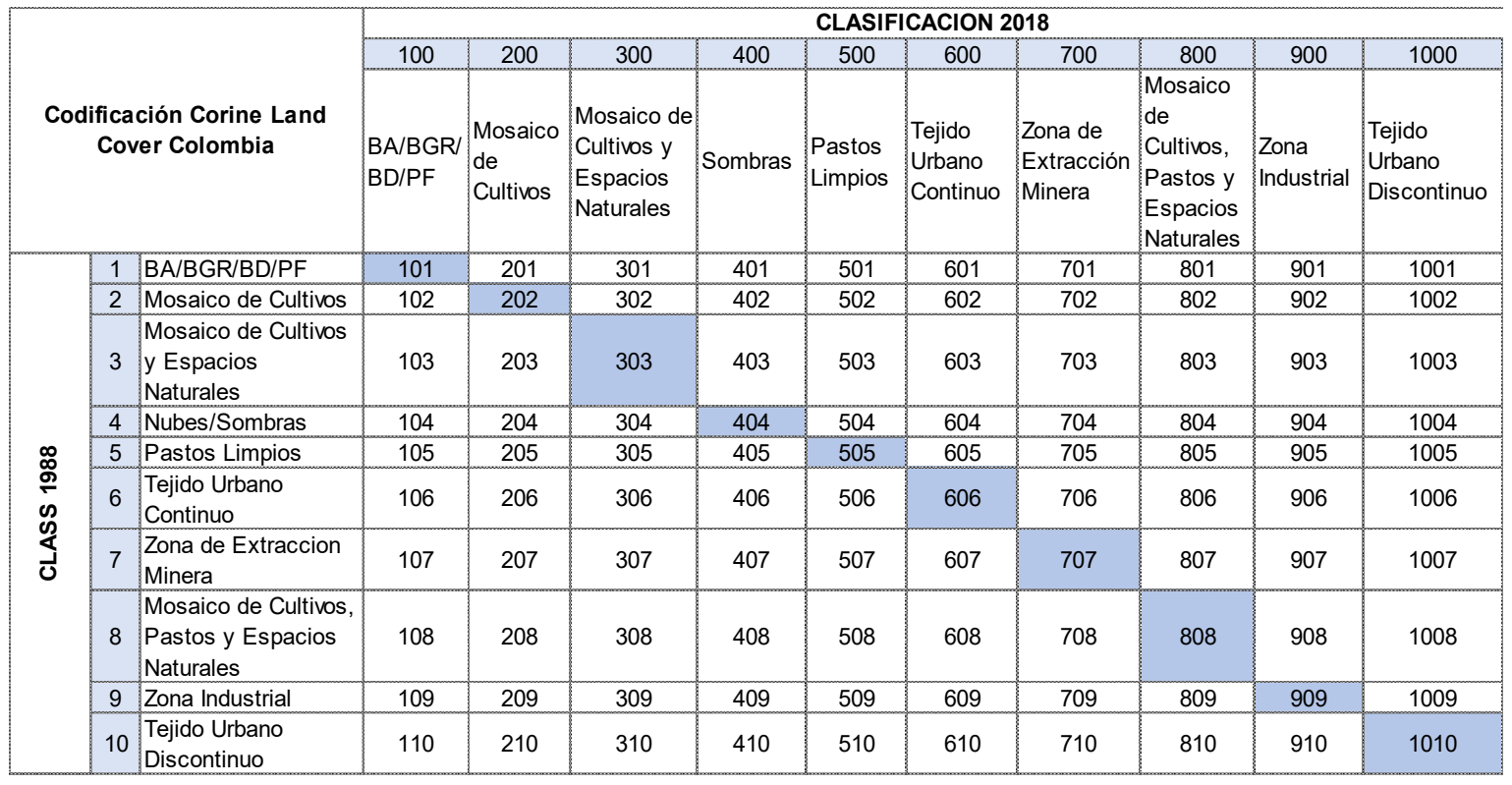

Fuente: Elaboración de la autora

La implementación de la matriz anterior se llevó a cabo en el software ArcGIS 10.5 mediante el uso de la herramienta de geoprocesamiento $\rightarrow$ Intersect, obteniendo las áreas correspondientes a cambios o permanencias en el periodo estudiado (llustración 38).

Ilustración 38: Mapa de Cambios y Persistencias en el periodo 1988-2018
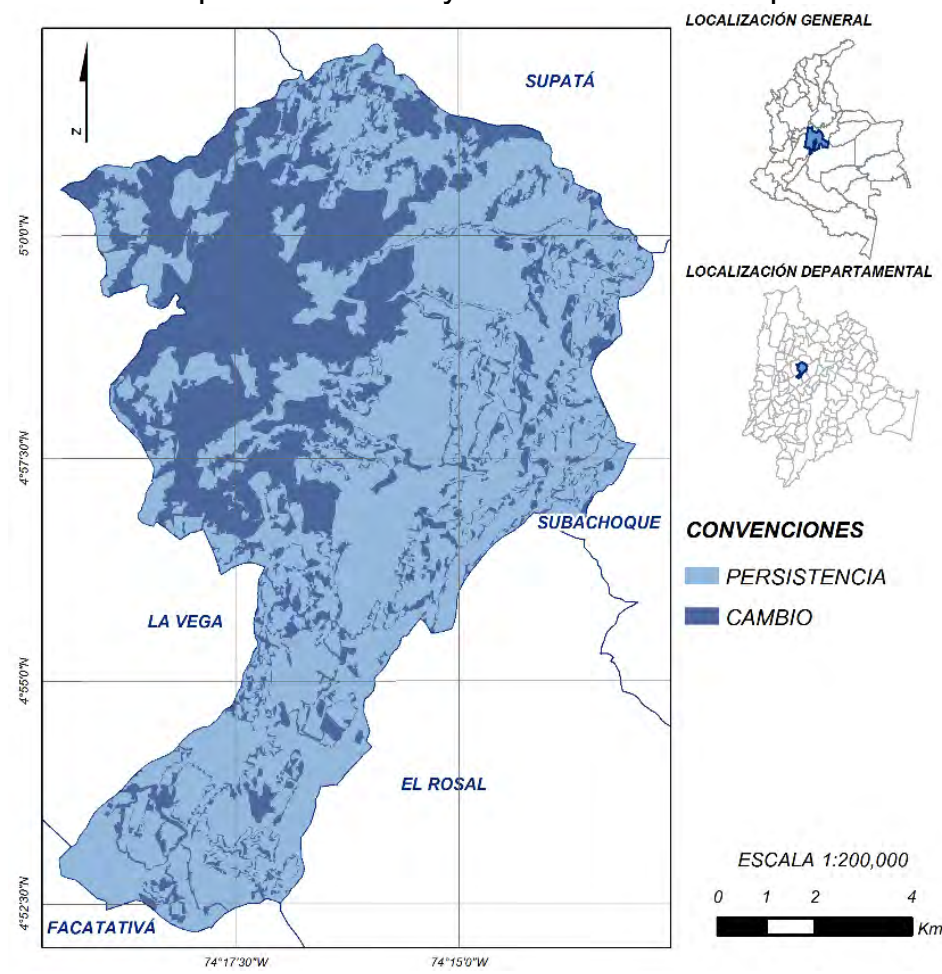

Fuente: Elaboración de la autora 
Las áreas que no sufrieron cambios, es decir, las zonas estables o que persisten en el periodo analizado, se presentan en la diagonal principal de la Tabla 13; los elementos fuera de la diagonal principal corresponden a las transiciones ocurridas entre categorías; la fila Total 2018 y la columna Total 1988 indican el área total que ocupa cada clase en los periodos indicados respectivamente.

De esta manera, la fila denominada ganancias, indica la proporción del paisaje que experimentó un aumento entre 1988 y 2018, es decir, la diferencia entre los valores de Total 2018 y lo que permaneció estable y por último, la columna designada como pérdidas indica la disminución que tuvo cada categoría en el periodo evaluado, es decir, la diferencia entre Total 1988 y los valores de la diagonal principal. 
Tabla 13: Resultado de la Matriz de Tabulación Cruzada (Áreas en ha)

\begin{tabular}{|c|c|c|c|c|c|c|c|c|c|c|c|c|c|c|}
\hline \multirow{3}{*}{\multicolumn{3}{|c|}{$\begin{array}{l}\text { Coberturas Corine } \\
\text { Land Cover Colombia }\end{array}$}} & \multicolumn{12}{|c|}{ CLASIFICACIÓN 2018} \\
\hline & & & 100 & 200 & \multirow{2}{*}{\begin{tabular}{l}
\multicolumn{1}{c}{300} \\
Mosaico \\
de \\
Cultivos \\
y \\
Espacios \\
Naturales \\
\end{tabular}} & 400 & 500 & 600 & 700 & 800 & 900 & 1000 & \multirow{2}{*}{$\begin{array}{l}\text { Total } \\
1988\end{array}$} & \multirow[b]{2}{*}{ Pérdidas } \\
\hline & & & $\mathrm{BA} / \mathrm{BR} / \mathrm{BD} / \mathrm{PF}$ & $\begin{array}{l}\text { Mosaico } \\
\text { de } \\
\text { Cultivos }\end{array}$ & & Sombras & $\begin{array}{l}\text { Pastos } \\
\text { Limpios }\end{array}$ & \begin{tabular}{|l|} 
Tejido \\
Urbano \\
Continuo
\end{tabular} & $\begin{array}{l}\text { Zona de } \\
\text { Extracción } \\
\text { Minera }\end{array}$ & $\begin{array}{l}\text { Mosaico } \\
\text { de } \\
\text { Cultivos, } \\
\text { Pastos y } \\
\text { Espacios } \\
\text { Naturales }\end{array}$ & $\begin{array}{l}\text { Zona } \\
\text { Industrial }\end{array}$ & $\begin{array}{l}\text { Tejido } \\
\text { Urbano } \\
\text { Discontinuo }\end{array}$ & & \\
\hline \multirow{12}{*}{ 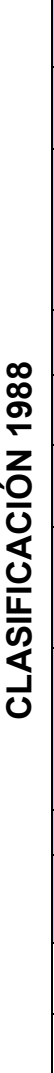 } & 1 & BA/BR/BD/PF & 2410,2 & 31,2 & 0,0 & 15,6 & 410,0 & 9,0 & 11,1 & 0,0 & 6,3 & 1,1 & 2894,6 & 484,4 \\
\hline & 2 & $\begin{array}{l}\text { Mosaico de } \\
\text { Cultivos }\end{array}$ & 228,8 & 835,8 & 381,6 & 0,0 & 1136,4 & 46,5 & 0,0 & 386,3 & 0,0 & 231,2 & 3246,7 & 2410,9 \\
\hline & 3 & $\begin{array}{l}\text { Mosaico de } \\
\text { Cultivos y } \\
\text { Espacios } \\
\text { Naturales }\end{array}$ & 23,6 & 50,0 & 5,0 & 0,3 & 87,9 & 18,9 & 0,0 & 1,0 & 0,0 & 15,4 & 202,1 & 197,2 \\
\hline & 4 & Nubes/Sombras & 195,8 & 0,0 & 0,0 & 26,8 & 132,9 & 0,0 & 0,0 & 0,0 & 0,0 & 0,0 & 355,6 & 328,7 \\
\hline & 5 & Pastos Limpios & 724,5 & 79,9 & 30,9 & 0,4 & 4173,2 & 34,9 & 2,9 & 6,8 & 2,1 & 34,0 & 5089,4 & 916,2 \\
\hline & 6 & $\begin{array}{l}\text { Tejido Urbano } \\
\text { Continuo }\end{array}$ & 0,0 & 0,0 & 2,6 & 0,0 & 0,0 & 24,6 & 0,0 & 0,0 & 0,0 & 0,0 & 27,2 & 2,6 \\
\hline & 7 & $\begin{array}{l}\text { Zona de } \\
\text { Extracción } \\
\text { Minera }\end{array}$ & 0,0 & 0,0 & 0,0 & 0,0 & 0,3 & 0,0 & 4,1 & 0,0 & 0,0 & 0,0 & 4,3 & 0,3 \\
\hline & 8 & $\begin{array}{l}\text { Mosaico de } \\
\text { Cultivos, Pastos } \\
\text { y Espacios } \\
\text { Naturales }\end{array}$ & 0,0 & 0,0 & 0,0 & 0,0 & 0,0 & 0,0 & 0,0 & 0,0 & 0,0 & 0,0 & 0,0 & 0,0 \\
\hline & 9 & Zona Industrial & 0,0 & 0,0 & 0,0 & 0,0 & 0,0 & 0,0 & 0,0 & 0,0 & 0,0 & 0,0 & 0,0 & 0,0 \\
\hline & 10 & $\begin{array}{l}\text { Tejido Urbano } \\
\text { Discontinuo }\end{array}$ & 0,0 & 0,0 & 0,0 & 0,0 & 0,0 & 0,0 & 0,0 & 0,0 & 0,0 & 0,0 & 0,0 & 0,0 \\
\hline & & Total 2018 & 3582,9 & 996,9 & 420,0 & 43,2 & 5940,8 & 133,8 & 18,1 & 394,1 & 8,4 & 281,6 & & \\
\hline & & Ganancias & 1172,7 & 161,1 & 415,0 & 16,4 & 1767,6 & 109,2 & 14,0 & 394,1 & 8,4 & 281,6 & & \\
\hline
\end{tabular}


Finalmente y como resultado de todos los procesos anteriores, se llegó a establecer el comportamiento de las coberturas presentes en el municipio de San Francisco Cundinamarca para el periodo comprendido entre 1988 y 2018. Lo anterior, se materializa en los mapas de cobertura del suelo para ambas épocas con una escala grafica de 1:100.000 (Ilustración 39 ).

\section{Ilustración 39: Mapa de cobertura del suelo San Francisco de Sales}

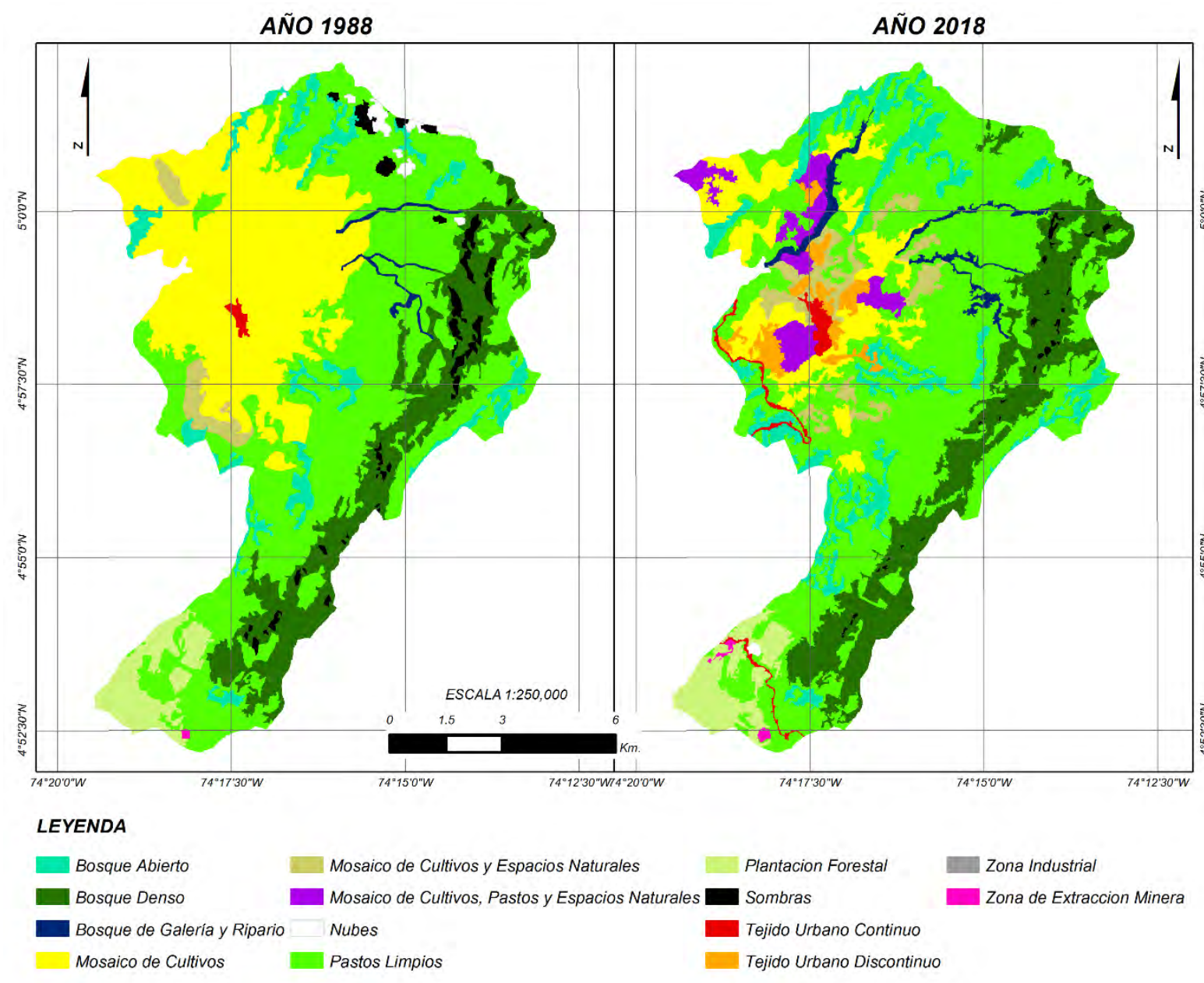

Fuente: Elaboración de la autora

\section{RESULTADOS}

Entre los cambios más significativos se encuentra el incremento de los territorios artificializados, apareciendo consigo dos nuevas coberturas correspondientes a tejido urbano discontinuo y zonas industriales, por otro lado, en territorios agrícolas aparece también una nueva cobertura definida como mosaico de cultivos, pastos y 
espacios naturales. Además, se encontró una significativa disminución en la cobertura correspondiente a mosaico de cultivos (llustración 40).

Ilustración 40: Cobertura de la tierra CLC identificadas en el municipio de San Francisco (Cund.) para el periodo $1988-2018$

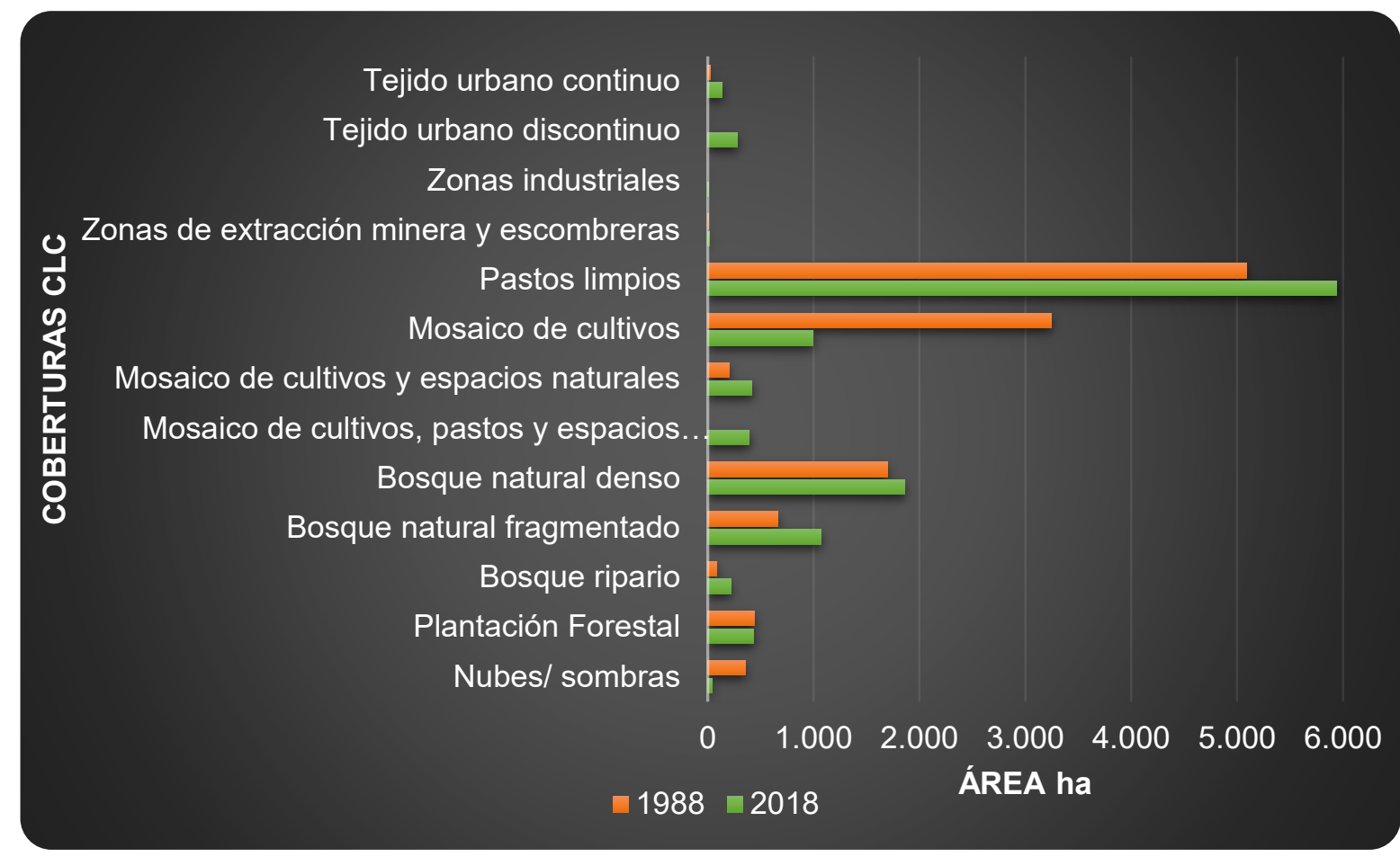

Fuente: Elaboración de la autora

En el municipio de San Francisco actualmente predominan las tierras de pastos limpios, que constituye la matriz del paisaje, con una extensión de 5.941 ha cubriendo el $50 \%$ del territorio, asociándose con áreas de actividad pecuaria, encontrándose ganado bovino, porcino, equino, caprino, ovino y aviar. En segundo lugar, con 3.583 ha equivalente al $30 \%$ del municipio, se encuentran los bosques y áreas seminaturales (bosque natural denso, bosque natural fragmentado, bosque ripario y plantación forestal). El 20\% del área municipal restante, está distribuido mayormente en áreas agrícolas heterogéneas y con menor medida en territorios artificializados.

A continuación se explican de manera más detallada los resultados encontrados: 


\subsection{Territorios Artificializados}

\section{Ilustración 41: Territorios Artificializados}

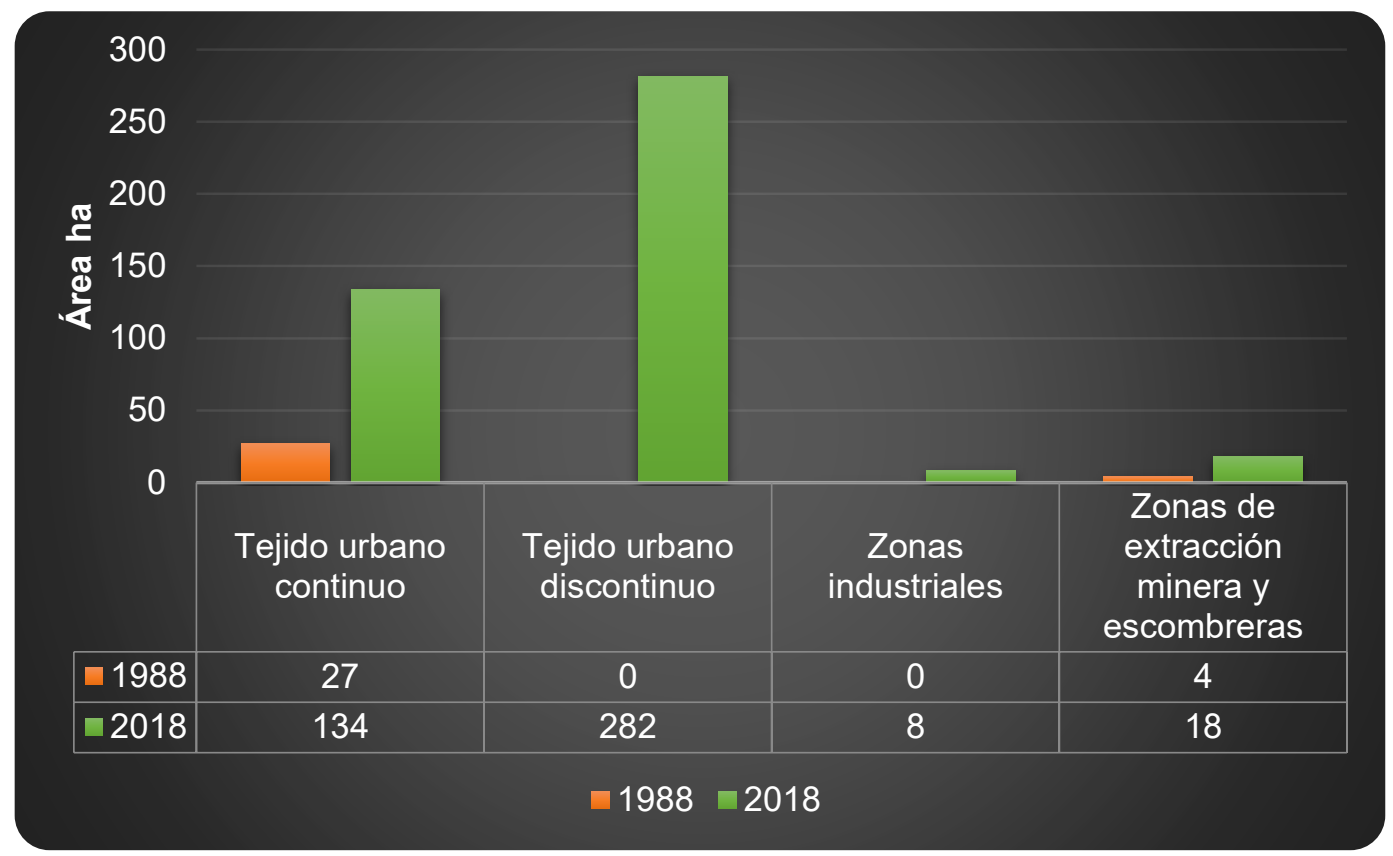

Fuente: Elaboración de la autora

En los últimos 30 años (periodo de estudio), la ocupación del territorio rural se ha visto presionada por procesos socio-espaciales de tipo urbano, como: la expansión del tejido urbano continuo (llustración 41), correspondiente al centro poblado y la construcción acelerada de casas de campo, con lo cual aparece una nueva cobertura denominada tejido urbano discontinuo, reemplazando a otras coberturas tales como los mosaicos de cultivos, que predominaban en los años noventa.

Se ha venido presentando un fenómeno de microfundios, que significa la fragmentación de la tierra en pequeños loteos, este es el llamado negocio de finca raíz; donde se pueden encontrar terrenos hasta de $200 \mathrm{~m}^{2}$ en el área rural. Este, se ha convertido en una competencia desigual para la agricultura, dado que resulta más rentable convertir grandes extensiones de tierra en lotes de recreo improductivos, que el de cultivar las tierras. Como se pudo constatar en estos 30 años ha aumentado el número de predios del municipio, pasando de 1.762 predios rurales en el año 1991 a 4.155 predios rurales en el año 2016 (Gobernación de Cundinamarca b, 2019), un aumento del 136\%, una evidente disminución del tamaño promedio de las fincas históricamente agricultoras. 
Por otro lado, aparece una nueva cobertura denominada zonas Industriales con un área de 8 ha, la cual no es representativa pero no menos importante para el desarrollo económico del municipio; en esta área se ubica la empresa inmunizadora de maderas San Francisco, la cual se encarga de la extracción de maderas, siendo la única empresa dedicada a este oficio en la zona y en la cual se procesan las plantaciones forestales que existen en los alrededores.

\subsection{Territorios Agrícolas}

Ilustración 42: Territorios Agrícolas

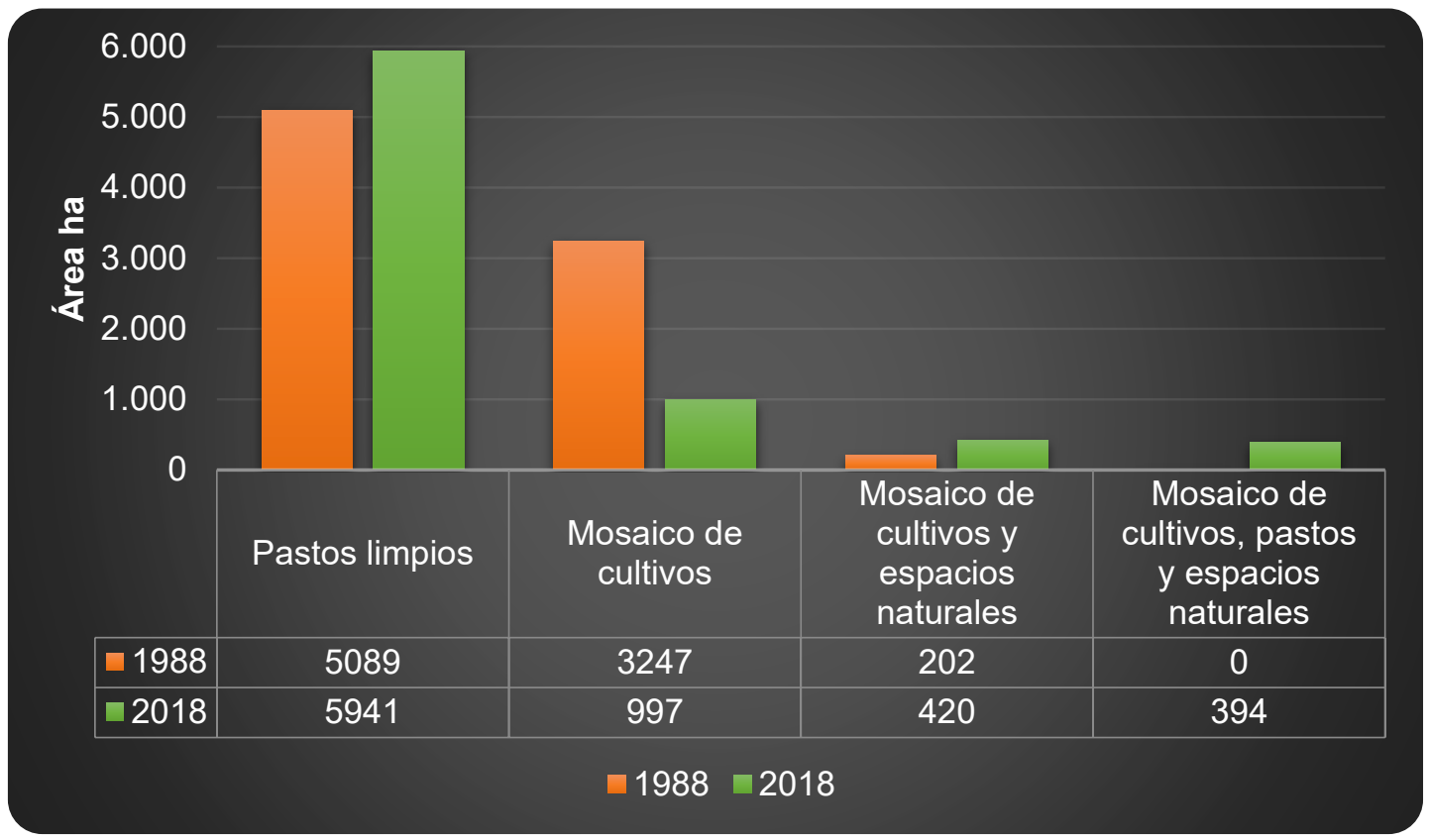

Fuente: Elaboración de la autora

La actividad económica del municipio gira en torno de dos actividades básicas: la ganadería y la agricultura, y en pequeña escala la explotación de canteras (trasformación de arcillas y arenas).

El 50\% del área total del municipio, hoy día corresponde a zonas cubiertas por pastos, las principales especies son el Pennisetum clandestinum (Kikuyo) y pastos de corte como el Axonopus scoparius (Imperial) y el Híbrido entre Pennisetum purpureum y Pennisetum typhoides (King grass). Hoy por hoy, son utilizados para ganadería semi-extensiva y otros tantos se encuentran sin uso aparente. Las razas predominantes son: el cruce con Cebú Normando y pardo, para la ceba integral; el Normando y el Holstein; para doble propósito y el Holstein para lechería 
garantizada. Esta actividad genera en promedio un empleo permanente por cada seis hectáreas, según lo descrito por la Alcaldía Municipal de San Francisco Cundinamarca (Acuerdo Municipal No. 012 de 2016 ). Este uso se ha mantenido constante con el paso de los años, con apenas un incremento del $17 \%$ para el periodo estudiado.

Por otro lado, la agricultura es la fuente primordial de trabajo de los habitantes de San Francisco, de la cual resultan más familias beneficiadas, dado que, es una actividad que en época de cosecha genera más empleo por unidad de área al compararse con otras actividades, como por ejemplo el comercio y la ganadería. Los cultivos que mayormente están presentes son: Café, caña de azúcar, maíz, cítricos, plátano y algunos cultivos que se producen en menor escala como aguacate, tomate, frijol, yuca y arveja. Estos últimos, son utilizados principalmente para consumo en los hogares y el excedente para la comercialización dentro del mismo municipio (Alcaldía Municipal de San Francisco Cundinamarca, Acuerdo Municipal No. 012 de 2016 ).

Del área total obtenida para la cobertura de mosaico de cultivos y de acuerdo con el anuario estadístico presentado por la Gobernación de Cundinamarca para el año 2018, se tienen los porcentajes de ocupación de los diferentes cultivos, siendo el café el cultivo predominante con un $63 \%$, seguido por el plátano (incluyendo banano y guineo) y cítricos con un $19 \%$ y $13 \%$ respectivamente. El restante $5 \%$ de los cultivos son: maíz, caña panelera, aguacate y demás productos mencionados en el párrafo anterior para consumo en los hogares.

Cabe reconocer que, este municipio continúa sosteniendo un enfoque mayormente cafetero; pero no en las mismas proporciones que lo caracterizaban en la década de los noventa, puesto que, entre 1980 y 2000 el cultivo de café disminuyó un 34\% y entre 2000 y 2018 un 47\%, pasando de tener 1.773 ha para el año 1980, 1.175 ha para el año 2000 y finalmente 622 ha para el año 2018, lo anterior, según datos del censo cafetero presentados por la Secretaría de Planeación en sus respectivos anuarios estadísticos (Gobernación de Cundinamarca a, 2019). Además, Barreto Calderón (2015) afirma que durante el periodo de 1990 a 1997, el desempeño de la agricultura fue deficiente: "el café tuvo amplias fluctuaciones a lo largo de este periodo generado por la tendencia negativa a nivel mundial y como resultado de la reducción de plantaciones posterior a la caída del precio internacional en 1989" 
(pág. 21), como lo señala la Revista Dinero (2013), resultado del fin del Pacto Internacional del Café que se dio el lunes 3 de Julio de 1989 en Londres, ese día se consolidó la liberación del mercado cafetero para los productores, y así se dio fin al sistema de mercado que garantizó niveles de precio razonables para los agricultores en todo el planeta durante casi tres décadas. Sumado a lo anterior, Bustillo Pardey (2007) destaca en su investigación que en el año 1988 se introdujo en Colombia la plaga más importante que ha afectado el cultivo de café, enfermando rápidamente las plantaciones y propagándose a gran velocidad, ocasionando grandes pérdidas en las cosechas y mayor inversión en el cuidado de los cultivos.

Las tierras dedicadas a la agricultura representan hoy día tan solo el $8 \%$ del territorio de San Francisco, una variación dramática en los últimos 30 años, observándose una disminución del $69 \%$ en el área total dedicada a los diferentes cultivos, pasando de 3.247 ha en el año 1988 a 997 ha en el 2018 (Ilustración 42). Lo anterior, como consecuencia de las crisis agropecuarias que ha afrontado el sector, desde la apertura económica marcada por los tratados de libre comercio firmados con otros países, la revaluación de la tasa de cambio, el desplome de las cotizaciones internacionales, la sequía de 1992, la violencia, las altas tasas de interés, entre otros factores como lo indica Barreto Calderón (2015), que acentuó en la década de los noventa, un detrimento permanente en la rentabilidad de la agricultura colombiana; a tal punto que, algunos cultivos han prácticamente desaparecido del municipio, como por ejemplo la caña de azúcar y la industria panelera; dado que no se han implementado políticas suficientes de apoyo al agricultor por parte del gobierno. En respuesta a esta problemática económica, las tierras han sido dedicadas a otros usos, como el establecimiento de praderas y fines recreativos (finca raíz).

Así mismo, se identifica un aumento del $108 \%$ en la cobertura de mosaico de cultivos y espacios naturales, que pasó de tener 202 ha en 1988 a 420 ha en 2018, y la aparición de una nueva cobertura denominada mosaico de cultivos, pastos y espacios naturales con un área de 394 ha. Se identificó que, el incremento de estas áreas se localiza en zonas donde para 1988 estaban ocupadas por mosaico de cultivos, con lo cual se ratifican las afirmaciones anteriores respecto a la disminución o sustitución de la agricultura limpia por otros usos 


\subsection{Bosques y Áreas Seminaturales}

Ilustración 43: Bosques y Áreas Seminaturales

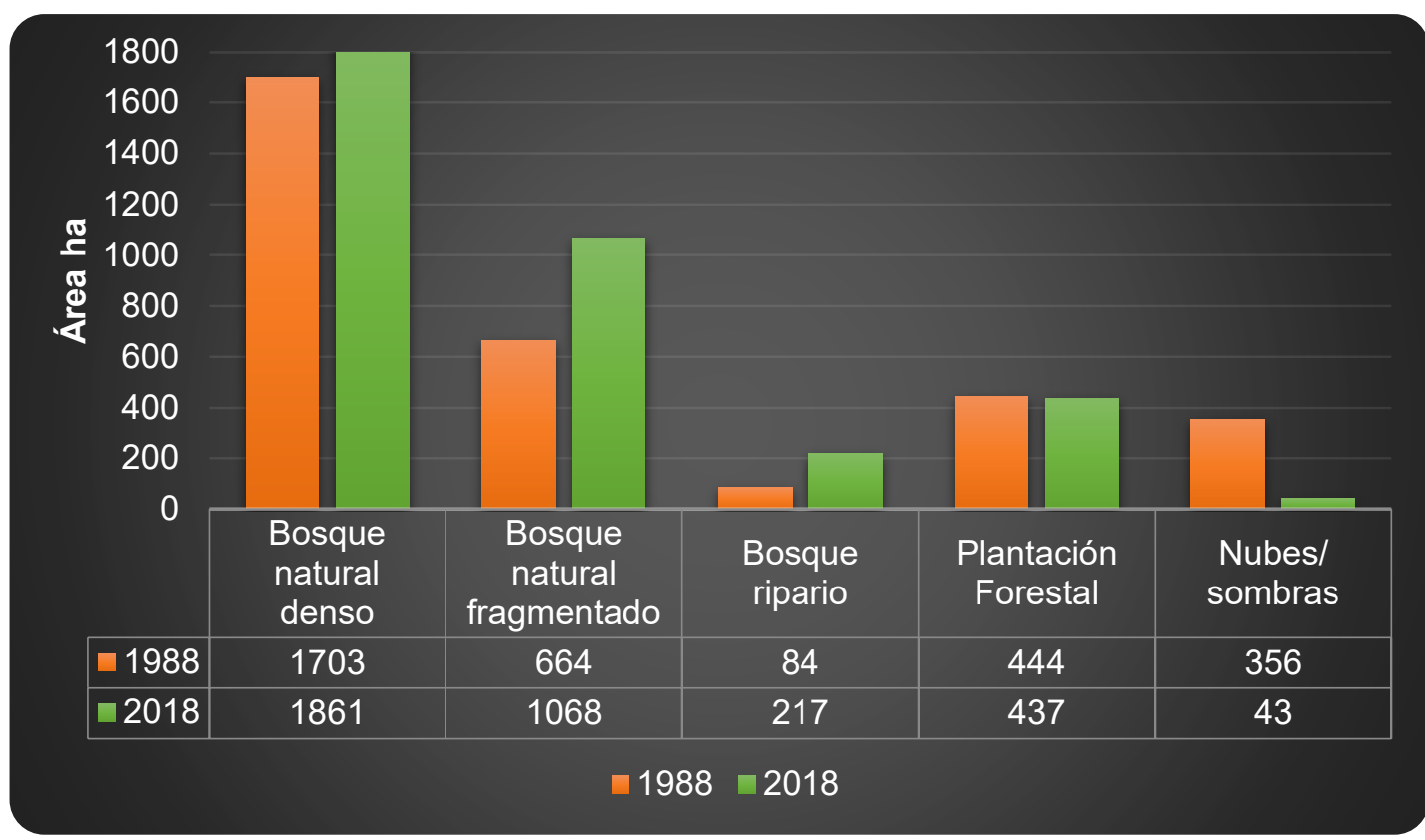

Fuente: Elaboración de la autora

Como se evidencia en la llustración 43, el bosque natural denso ocupa actualmente el $16 \%$ del municipio con un área de 1.868 ha, teniendo un incremento del $9 \%$ en el periodo estudiado. Según lo refiere la Alcaldía Municipal de San Francisco Cundinamarca (Acuerdo Municipal No. 012 de 2016 ), está ubicado en la zona Sur y Este, en las veredas de Sabaneta, El peñón, La Laja y San Miguel. Son bosques de protección únicamente, con el fin de conservar los nacimientos de agua, estos han estado fuera de la intervención antrópica ciertamente por las altas pendientes que presenta la zona.

Respecto del bosque natural fragmentado, se halló un incremento del $61 \%$, pasando de 664 ha en 1988 a 1.068 ha en 2018, este aumento se presentó en las zonas aledañas a los bosques naturales fragmentados existentes, principalmente en la faja noroccidental del municipio, reemplazando en su mayoría a fracciones de cultivos. Se evidencia también, su realce por el uso frecuente en los cercos naturales para delimitación de parcelas. 
Por otra parte, en la cobertura de bosque ripario aparece un aumento del $158 \%$, pasando de 84 ha en 1988 a 217 ha en 2018, con lo anterior, no puede afirmarse que ha sido un incremento real en la cobertura, dado que, al comparar las imágenes de satélite en las zonas donde se detectaron estas nuevas áreas, para el año 1988 no fue posible discriminarlas debido a la resolución espacial $(30 \mathrm{~m})$ ofrecida por la imagen Landsat. Además, aduciendo al hecho de que ésta cubierta aparece por la presencia de la quebrada El muña, esta área no es nueva, puede identificarse más fácilmente por la indiscutible mejora en la resolución espacial $(10,20$ y $60 \mathrm{~m})$ que ofrece hoy día el satélite Sentinel-2.

Por último, se encuentra la cobertura de plantación forestal, la cual ocupa actualmente el $4 \%$ del área total del municipio con un área de 437 ha. De acuerdo con los resultados obtenidos, esta no ha sufrido cambios considerables durante el periodo estudiado, conserva el patrón en la distribución espacial que lo hace fácilmente identificable en el proceso de clasificación, se localizan en la parte sur de la vereda Sabaneta y El Peñón. Su procesamiento y extracción se lleva a cabo dentro del mismo municipio por la empresa Inmunizadora San Francisco (Alcaldía Municipal de San Francisco Cundinamarca, Acuerdo Municipal No. 012 de 2016 ).

\subsection{Conflicto de uso del suelo}

De acuerdo a lo definido por el Ministerio de Agricultura y Desarrollo Rural (2012, p. 31) el conflicto de uso de suelo, se entiende como: "la discrepancia entre el uso actual que el hombre hace sobre el medio natural y el uso que debería tener de acuerdo a sus potencialidades y restricciones en todos los aspectos (económico, social, ambiental, cultural)". Para determinar el conflicto de uso de suelos en el municipio de San Francisco de Sales, se trabajó con la distribución espacial de las coberturas del suelo obtenidos para el año 2018 (Ilustración 44-izquierda) y el mapa de uso propuesto del suelo rural de Cundinamarca 1999 (Ilustración 44-derecha), este último es producto de la clasificación del suelo y los usos del suelo, conforme a lo establecido en los planes de ordenamiento territorial de cada municipio del departamento (Gobernación de Cundinamarca, 2007). Teniendo estos dos insumos, se realizó el cruce entre estos, obteniendo como resultado el mapa de conflicto de uso de suelos para la zona de estudio (llustración 45). En el Anexo 3 se presenta el producto resultante con mejor definición y escala. 
Ilustración 44: Mapa de cobertura del suelo 2018 y Mapa de uso propuesto del suelo 1999.
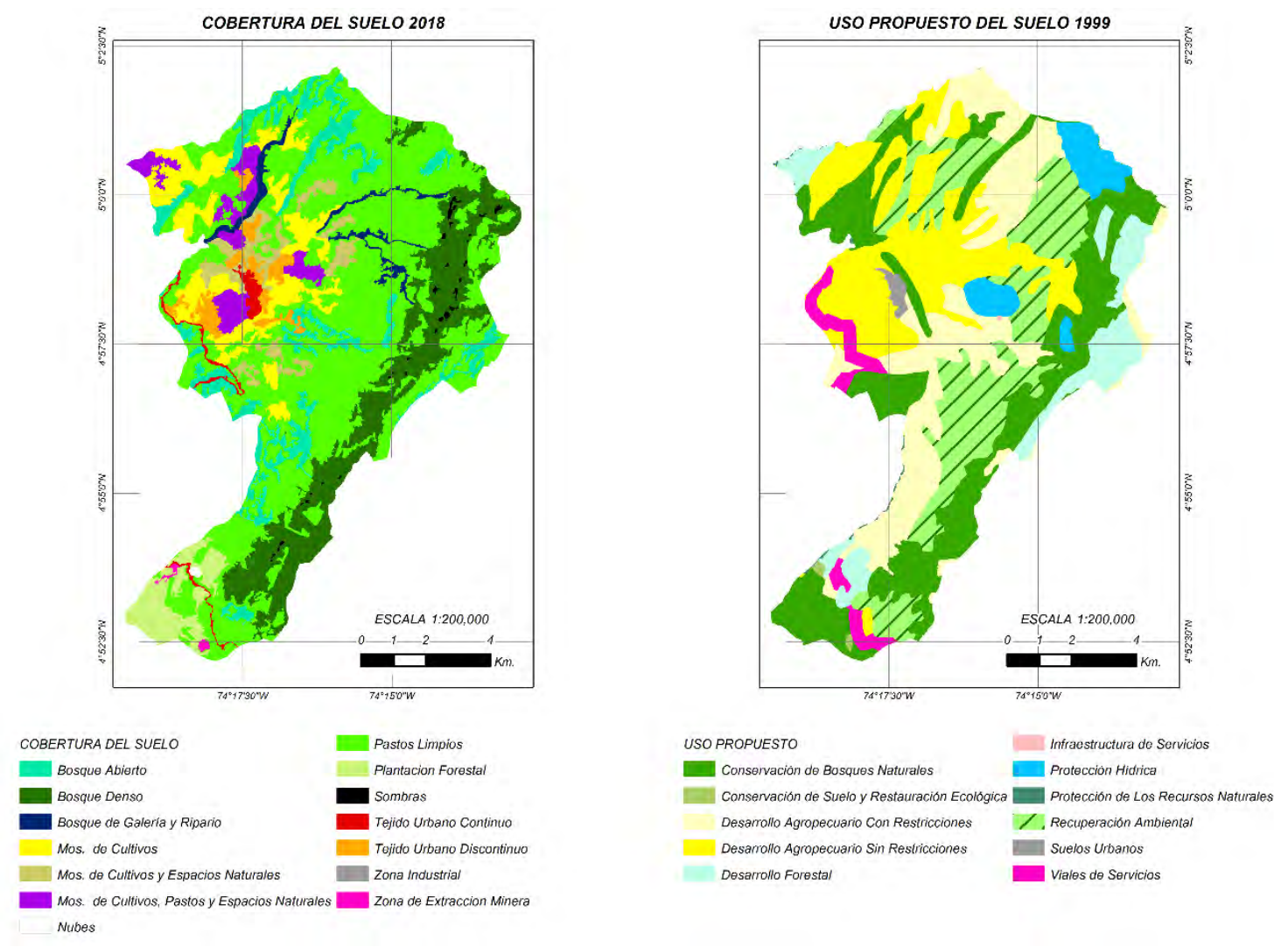

Fuente: Elaboración de la Autora

Las discrepancias en el mapa de conflicto de usos del suelo (llustración 45, se presenta al final como Anexo 4 para una mejor visualización) se clasificaron en tres categorías: Compatible, Restringido y No compatible. Los usos compatibles corresponde a las coberturas del suelo que no se oponen al uso principal del suelo definido por el municipio, por ejemplo la cobertura de bosque es afín o acorde a las zonas de conservación de bosques naturales. Por el contrario, el uso no compatible se refiere a aquellas coberturas que no coinciden con el propósito que el municipio estableció para esa zona, como ejemplo está una cobertura de mosaico de cultivos dentro de una zona urbana o una zona de protección hídrica. Por último, está el uso restringido el cual se entiende como aquellas coberturas que presentan un nivel de incompatibilidad con el uso principal y riesgos ambientales que aplicando medidas y control de las autoridades llevan al correcto aprovechamiento de suelo, esta última clasificación se hizo conforme en lo señalado por el Consejo Municipal de San Francisco Cundinamarca (Acuerdo Municipal No. 21 de 1999 ), en este se da la 
clasificación general de los usos del suelo, ejemplo de lo anterior se tiene con la zona de extracción minera que es considerada restringida en una zona de desarrollo agropecuario con restricción.

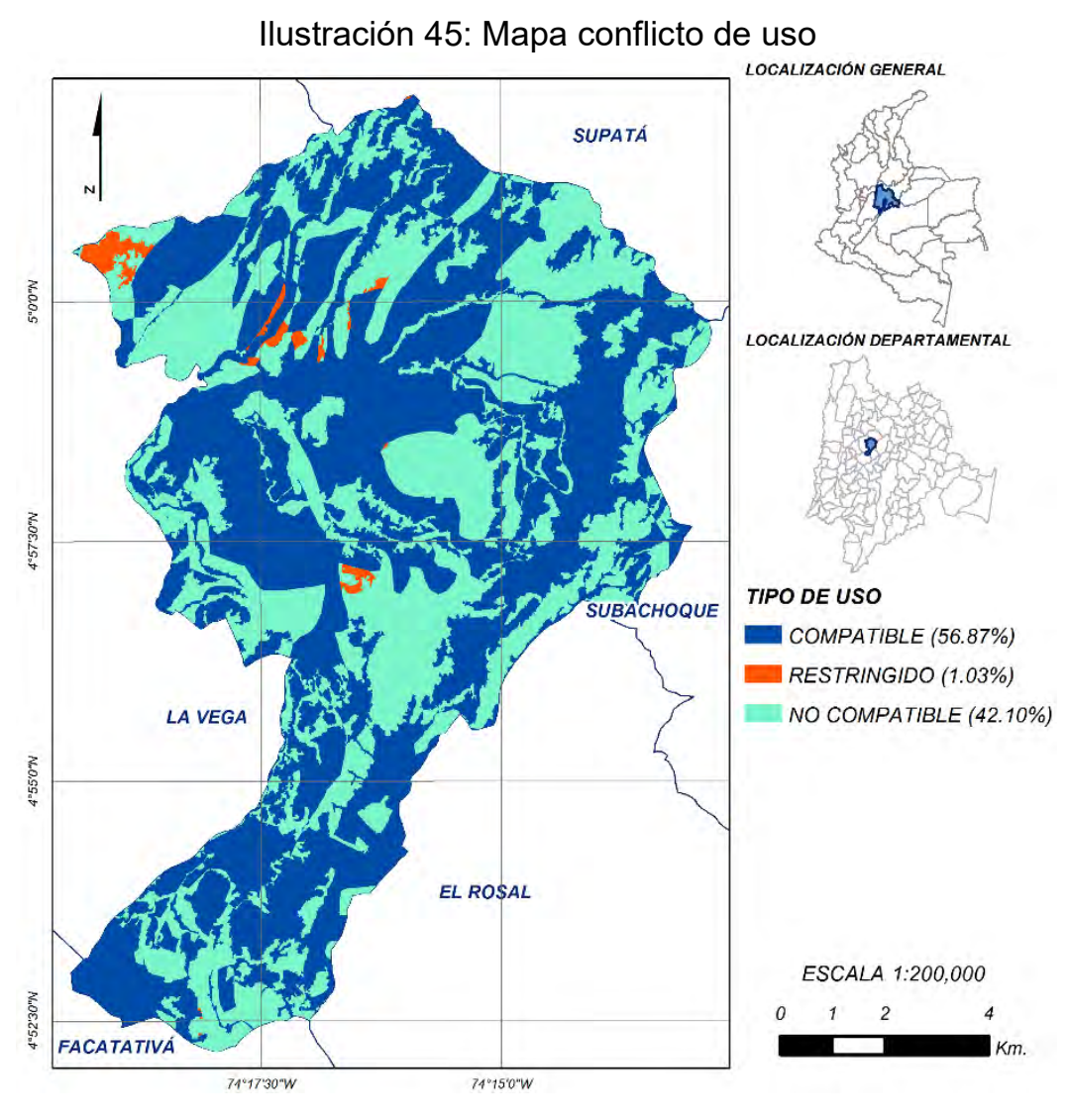

Fuente: Elaboración de la Autora

La compatibilidad en los usos del suelo actuales frente a los usos establecidos por el Esquema de Ordenamiento Territorial (EOT), alcanzó un 57\% del área municipal total, de los cuales $21 \%$ corresponde a pastos limpios que han sido aprovechados principalmente en actividades ganaderas, un $24 \%$ pertenece a la cobertura de bosques (denso, abierto y ripario) que en términos generales se ha mantenido y ha sido conservado, un $6 \%$ concierne a mosaicos de cultivos en su mayoría café y el $6 \%$ restante a las demás coberturas presentes en la zona de estudio.

En cuanto al uso no compatible se obtuvo un $42 \%$ del área total del municipio, destacándose de este un $29 \%$ correspondiente a pastos limpios, que a pesar de ser una de las principales fuentes de la economía municipal, se encuentra gran parte en discrepancia con las normas de uso del suelo señaladas por la autoridad, generando conflicto primordialmente con las zonas de: protección hídrica $(3 \%)$, 
desarrollo forestal (4\%), recuperación ambiental (14\%) y conservación de bosques $(8 \%)$.

Existe un 6\% de la cobertura de bosques en desacuerdo con el EOT, dado que el uso correspondiente debería ser de desarrollo agropecuario; pero esto se da en razón del uso de cercos naturales y algunas zonas de expansión libre del mismo, por tanto no es un problema significativo.

Por otro lado, se encuentra en discordancia la cobertura de tejido urbano discontinuo que ha venido reemplazando la agricultura propia del municipio. Si bien solamente representan el 2,5\% del territorio, ha venido en aumento estos últimos años con el fenómeno de microfundios que se mencionó en análisis anteriores, lo cual impacta directamente en su economía. 


\section{CONCLUSIONES}

Mediante la implementación de la Metodología Corine Land Cover adaptada para Colombia (CLC), se identificó espacialmente la distribución de la cobertura de los suelos del municipio de San Francisco (Cundinamarca) en las épocas 1988 y 2018. Para este propósito se aplicó la clasificación supervisada de imágenes de satélite de las épocas citadas, la imagen de 1988 procedente del sensor TM de Landsat 4 se clasificó en 10 categorías; por su parte la imagen de 2018 obtenida del sensor MSI de la Misión Sentinel 2 se clasificó en 13 clases. Lo anterior, se integró en los mapas de cobertura de 1988 y 2018 que representan el estado y configuración espacial de la zona de estudio.

La transición de usos del suelo encontrada en el municipio de San Francisco de Sales durante los últimos 30 años, fue identificada a través de la matriz de tabulación cruzada, permitiendo así, determinar aquellas zonas en donde hubo pérdidas (Mosaico de cultivos), ganancias (Tejido urbano continuo, bosque natural fragmentado, mosaico de cultivos y espacios naturales) o permanencia (Pastos limpios, Bosque natural denso, plantación forestal) de los usos de la tierra; del mismo modo, se encontraron nuevos usos (tejido urbano discontinuo y mosaico de cultivos, pastos, espacios naturales y zonas industriales) que finalmente mostraron la dinámica de los usos del suelo en la zona de estudio. En este sentido, es claro que el sector más afectado ha sido la agricultura, debido a que los cambios de uso del suelo han sido cada vez más frecuentes, observándose un fenómeno de praderización y loteo de parcelas, como consecuencia de la apertura económica que tuvo el país a principios de los noventa, sumado a la situación de violencia que se vivió durante esa época y que han desmotivado a los productores de la región.

De otro lado, si bien la actividad económica del municipio gira en torno de actividades como la agricultura y la ganadería, no se puede dejar de lado la explotación de canteras o el establecimiento de galpones (gallinas ponedoras y/o pollos de engorde), que si bien es en pequeña escala ha venido en aumento en los últimos tiempos y debe ser controlado por las autoridades locales, ya que por la naturaleza de estas actividades pueden ocasionar gran impacto medioambiental. 
El análisis multitemporal realizado derivó fundamentalmente en la identificación de la configuración espacial del municipio para estas últimas 3 décadas y a partir de este hecho analizar las dinámicas de cambio del uso del suelo; como resultado de lo mencionado se logró identificar aquellos fenómenos o factores que han impactado la región en el periodo de estudio, dichos factores están en el orden económico, social y ambiental. Para este primer orden se tiene la crisis agropecuaria de la década de los noventa, la revaluación de la tasa de cambio, las altas tasas de interés que terminaron en el detrimento en la rentabilidad agrícola y sumado a esto la inexistencia de políticas de apoyo al sector cuyo efecto colateral fue la desaparición de cultivos y por consiguiente las tierras fueron destinadas a otros usos más rentables. Dentro del orden social se encontró el fenómeno de la violencia que ha afectado al país generando desplazamiento y abandono de las tierras. Y finalmente el orden ambiental comprende la sequía del año 1992 y la plaga (broca) que afectó los cultivos de café con su llegada en el año 1988.

Hoy día, con los avances tecnológicos en percepción remota, se permite entre otras, identificar los tipos de cobertura del suelo mediante una clasificación supervisada o no supervisada en forma más eficiente y económica que con el método convencional de recorrido y toma de datos en campo, logrando abarcar grandes extensiones de territorio y optimizando los tiempos para obtener resultados. Pese a que, pueden existir errores en la clasificación esto puede ser validado y/o corregido con una simple verificación en terreno de puntos de muestreo. Si bien, puede parecer dificultoso realizar los diseños de muestreo, actualmente los avances tecnológicos tales como los Smartphone, GPS, el acceso a internet satelital, entre otras, facilitan la labor de verificación en el terreno, un procedimiento necesario y adecuado, ya que se obtiene total certeza del dato relevado y da mayor confianza en el resultado final de cualquier proyecto.

La metodología empleada en este trabajo, que reunió la combinación de técnicas de Teledetección, SIG y análisis estadístico, ha demostrado su potencial para estudios en los que se involucren los cambios de usos de suelo, ya que no sólo permite obtener imágenes categorizadas de las coberturas, sino que permite cuantificar los cambios y observar las dinámicas de relación entre ellos, así se gana 
un indiscutible entendimiento sobre las diferentes coberturas que se están interrelacionando.

Disponer de mapas de uso de suelo es importante para la gestión sostenible de recursos de cualquier territorio, además es la base para el estudio de indicadores ambientales y cambio climático. Hoy día, es indispensable el conocimiento de la superficie del suelo antes de realizar cualquier interacción en la atmósfera. Por lo cual, se recomienda la actualización constante del estado de los suelos y su vocación. Además, su disponibilidad en formatos adecuados para consulta pública en cada una de las páginas oficiales del municipio o departamento.

Este estudio, como labor académica queda a disposición del público interesado almacenado en una geodatabase (Anexo 5) que consta de todos los insumos utilizados y los productos temáticos resultantes de la interpretación, clasificación y tabulación cruzada que se llevaron a cabo para obtener el mapa de uso actual del suelo para el municipio de San Francisco. 


\section{BIBLIOGRAFÍA}

Alcaldía Municipal de San Francisco Cundinamarca. (Acuerdo Municipal No. 012 de 2016 ). Por el cual se adopta el Plan de Desarrollo "Sumate al Cambio 20162019". Recuperado el 11 de 11 de 2020, de http://www.sanfranciscocundinamarca.gov.co/metas-objetivos-e-indicadores/plan-de-desarrollosumate-al-cambio-2016--2019

Arredondo, H. A., \& Rodriguez, O. E. (2005). Manual para el manejo y procesamiento de imagenes satelitales obtenidas del sensor remoto MODIS de la NASA, aplicado en estudios de Ingenieria Civil. Bogotá D.C.

Barreto Calderón, N. E. (01 de 01 de 2015). Sector agrícola colombiano en el tratado de libre comercio con Estados Unidos. (U. d. Posgrado, Ed.) Recuperado el 13 de 11 de 2020, de Biblioteca Prof. Emérito Alfredo L. Palacios: http://bibliotecadigital.econ.uba.ar/download/tpos/15020350_BarretoCalderonNE.pdf

Blasi , C., Smiraglia , D., \& Carranza , M. (2003). Analisi multitemporale del paesaggio e classificazione gerarchica del territorio: il caso dei Monti Lepini (Italia centrale). Informatore Botanico Italiano.

Boca, T., \& Rodríguez, G. (27 de 06 de 2012). Métodos estadísticos de la evaluación de la exactitud de productos derivados de sensores remotos. Obtenido de Instituto de Clima y Agua, INTA Castelar: https://inta.gob.ar/documentos/metodos-estadisticos-de-la-evaluacion-de-laexactitud-de-productos-derivados-de-sensores-remotos

Bustillo Pardey, Á. E. (01 de 02 de 2007). El manejo de cafetales y su relación con el control de la broca del café en Colombia. Federacion Nacional de Cafeteros de Colombia, Caldas. Manizales: CENICAFE. Recuperado el 28 de 03 de 2020, de Repositorio Difital del Centro Nacional de Investigaciones de Café: http://biblioteca.cenicafe.org/handle/10778/579

Cabrera Montenegro, E., Galindo García, G., Vargas Galvis, D., García Dávila, M. C., \& Ordóñez Castro, M. F. (2011). Protocolo de procesamiento digital de imágenes para la cuantificación de la deforestación en Colombia Nivel 
subnacional -Escala gruesa y fina. Instituto de Hidrología, Meteorología y Estudios Ambientales-IDEAM, 44 p. Bogotá D.C, Colombia: Scripto Ltda. Recuperado el 06 de 06 de 2019, de http://www.ideam.gov.co/documents/13257/13817/Protocolo+Subnacional+ PDI.pdf

Castro M, D. (2010). Modelo económico y social para Cundinamarca en el marco de la Región Capital: reformas y políticas de cara al futuro. Recuperado el 14 de 11 de 2018, de FEDESARROLLO: https://www.repository.fedesarrollo.org.co/bitstream/handle/11445/201/Mod elo\%20Economico\%20Cundinamarca-Entrega\%20Final-septiembre-152010.pdf? sequence $=2 \&$ isAllowed $=y$

Chávez , P. S. (1996). Image-Based Atmospheric Corrections - Revisited and Improved Photogrammetric Engineering and Remote Sensing. American Society of Photogrammetry, 62.

Chuvieco, E. (1990). Fundamentos de Teledetección Espacial. Madrid: RIALP.

Chuvieco, E. (1995). Fundamentos de Teledetección Espacial. (RIALP S.A, Ed.) Recuperado el 09 de 11 de 2020, de http://pdfhumanidades.com/sites/default/files/apuntes/FUNDAMENTOS-DETELEDETECCION-EMILIO-CHUVIECO.pdf

Chuvieco, E. (2008). Teledetección Ambiental: La observación de la Tierra desde el espacio. Barcelona: Editorial Ariel. 594 pp.

Climate-Data.Org. (11 de 2020). Obtenido de https://es.climate-data.org/americadel-sur/colombia/cundinamarca/san-francisco-49889/

Cogedo , L. (2016). Semi-Automatic Classification Plugin Documentation,pág. 132 y 133., Versión 6.4.0.2. doi: http://dx.doi.org/10.13140/RG.2.2.29474.02242/1

Consejo Municipal de San Francisco Cundinamarca. (Acuerdo Municipal No. 21 de 1999 ). Por medio del cual se adopta el esquema de ordenamiento territorial municipal EOT. Recuperado el 11 de 03 de 2020, de https://sanfranciscocundinamarca.micolombiadigital.gov.co/sites/sanfrancisc 
ocundinamarca/content/files/000022/1087_eot_esquema_de_ordenamiento _territorial_san_francisco_cundinamarca_nuestro_compromiso_san_francis co_municipio_de_todos_5.pdf

CORMAGDALENA. (14 de 11 de 2019). La Corporación. Obtenido de http://www.cormagdalena.gov.co/

DGAEA. (1996). Indicadores Ambientales: Una propuesta para España. En Ministerio de Medio Ambiente. Madrid: Dirección General de Calidad y Evaluación Ambiental.

Di Somma, A., \& Smiraglia, D. (2009). II Corine Land Cover e gli indici di struttura per l'analisi del cambiamento del territorio. II Caso della Regione Lazio. . Geografia, 1-20.

Dinero. (21 de 08 de 2013). El fin del Pacto Cafetero. Recuperado el 11 de 05 de 2019, de Revista Dinero: https://www.dinero.com/edicionimpresa/caratula/articulo/el-fin-del-pacto-cafetero/182429

Eastman, J., McKENDRY, J., \& Fulk, M. (1994). UNITAR Explorations in GIS Technology, vol. 1: Change and Time Series Analysis. Geneve, Switzer-land.

ESA a. (2015). THE EUROPEAN SPACE AGECY, Sentinel-2 User Handbook. Recuperado el 10 de 11 de 2020, de https://sentinels.copernicus.eu/documents/247904/685211/Sentinel2_User_Handbook

ESA a. (2020). THE EUROPEAN SPACE AGECY, Applications. Recuperado el 23 de 03 de 2020, de Facts and figures Sentinel 2: http://www.esa.int/Applications/Observing_the_Earth/Copernicus/Sentinel2/Facts_and_figures

ESA b. (2015). THE EUROPEAN SPACE AGECY, Sentinel-2 Products Specification Document. Recuperado el 10 de 11 de 2020, de ESA Sentinel 2 PDGS Core Procurement:

https://sentinel.esa.int/documents/247904/349490/S2_MSI_Product_Specifi cation.pdf 
ESA b. (2020). THE EUROPEAN SPACE AGECY, Sentinel Missions. Recuperado el 23 de 03 de 2020, de Sentinel Overview: https://sentinel.esa.int/web/sentinel/missions

Esperbent, C., \& Migliorati , M. (2018). SAOCOM es el mayor desafío que ha tenido el país en el área satelital. Revista de Investigaciones Agropecuarias RIA, 44(3), 280-285.

Fondo de Inversión para la Paz. (2001). Panorama Actual de Cundinamarca Publicación del Observatorio del programa Presidencial de Derechos Humanos y Derecho Internacional Humanitario. (Vicepresidencia de la República, Ed.) Recuperado el 09 de 11 de 2020, de https://www.researchgate.net/publication/319141175_PANORAMA_ACTUA

L_DE_CUNDINAMARCA/citation/download

Franzosi, C. (2010). Aplicaciones del sensor Landsat. Buenos Aires, Argentina. Obtenido de Universidad de Bueno Aires.

GeoSpatial. (2013). Imágenes Ópticas. Recuperado el 20 de 11 de 2020, de http://www.geospatial.com.co/imagenes-de-satelite/img_opticas.html

Gobernación de Cundinamarca. (2002). mapa de uso actual y cobertura vegetal de los suelos del departamento de Cundinamarca a escala 1:25.000. Recuperado el 10 de 12 de 2019, de Secretaría de Agricultura y Desarrollo Rural - Unidad de Planeación Rural URPA: http://cundinet.cundinamarca.gov.co:8080/aplicaciones/gobernacion/centro Documental/docagricultura.nsf/0/2E2FBAB00B567B2F05257EB40056B9E5/\$FILE/Informe \%20Final\%20PDF.pdf

Gobernación de Cundinamarca. (2007). Elaboración y edición de la cartografía digital de la clasificación del suelo y usos del suelo rural de conformidad con el POT para los municipios del departamento de Cundinamarca. Bogotá: Secretaría de Planeación.

Gobernación de Cundinamarca a. (22 de 03 de 2019). Anuarios Estadísticos Cundinamarca. Recuperado el 10 de 02 de 2020, de Secretaría de 
Planeación:

http://www.cundinamarca.gov.co/Home/SecretariasEntidades.gc/Secretaria deplaneacion/SecretariadeplaneacionDespliegue/asestadisticas_contenidos /csecreplanea_estadis_anuario

Gobernación de Cundinamarca b. (10 de 10 de 2019). Base Catastral 2016 en Cundinamarca. (M. Rozo, Editor) Recuperado el 13 de 11 de 2020, de Mapas Estadísticas: https://mapasyestadisticas-cundinamarcamap.opendata.arcgis.com/datasets/base-catastral-2016-en-cundinamarcanumero-de-predios?geometry=-74.698\%2C4.813\%2C-73.815\%2C5.053

González V., M., \& Dalannais G., G. (1976). La percepción remota multibanda como un medio analítico para algunos aspectos del suelo, el agua y las plantas. Recuperado el 10 de 01 de 2020, de Biblioteca digital CEDOC-CIREN: http://bibliotecadigital.ciren.cl/bitstream/handle/123456789/16267/PI01874.p df?sequence $=1$

Guarín Nuñez, C. A. (2010). Pequeños productores de café en Cundinamarca. Análisis del Impacto del programa de renovación de cafetales en las características de sus cultivos. Recuperado el 09 de 11 de 2020, de Biblioteca Digital Universidad Nacional de Colombia: https://repositorio.unal.edu.co/bitstream/handle/unal/70367/794075.2010.pdf ?sequence=1\&isAllowed=y

Hernández Gómez, A., Rojas Robles, R., \& Sánchez Calderón, F. V. (2013). Cambios en el uso del suelo asociados a la expansión urbana y la planeación en el corregimiento de Pasquilla, zona rural de Bogotá (Colombia). (2. 2.-2. Cuadernos de Geografía: Revista Colombiana de Geografía, Ed.) Recuperado el 09 de 11 de 2020, de http://www.scielo.org.co/scielo.php?script=sci_arttext\&pid=S0121215X2013000200014\&lng=en\&tlng=es.

IDEAM. (1997). Coberturas de la tierra. Obtenido de http://www.ideam.gov.co/web/ecosistemas/coberturas-tierra

IDEAM. (14 de 11 de 2019). Acerca de la Entidad. Obtenido de http://www.ideam.gov.co/web/entidad/acerca-entidad 
IDEAM, CORMAGDALENA, IGAC. (2008). Mapa de cobertura de la tierra cuenca Magdalena - Cauca: Metodología CORINE Land Cover adaptada para Colombia escala 1: 100.000. 200p. + 164 hojas cartográficas. Bogotá D.C: Instituto de Hidrología, Meteorología y Estudios Ambientales, Instituto Geográfico Agustín Codazzi y Corporación Autónoma Regional del río Grande de La Magdalena. Recuperado el 04 de 03 de 2020, de http://documentacion.ideam.gov.co/openbiblio/bvirtual/021521/LIBROCORI NEFINAL.pdf

IDECA. (2019). Resolución Temporal. Recuperado el 22 de 04 de 2020, de Recursos - Glorario: https://www.ideca.gov.co/recursos/glosario/resoluciontemporal

IGAC. (14 de 11 de 2019). ¿Qué hacemos? Obtenido de Intituto Geográfico Agustín Codazzi: https://www.igac.gov.co/es/contenido/que-hacemos

INEGI. (2010). Aspectos técnicos de las imágenes. Mexico.

Ingeoexpert. (28 de 12 de 2018). Etapa de análisis de precisión y verificación de resultados. Recuperado el 12 de 11 de 2020, de Clasificaciones de imágenes de satélite: https://ingeoexpert.com/blog/articulo/clasificaciones-deimagenes-de-satelite/

INVAP. (2018). INVAP en la misión SAOCOM. Recuperado el 20 de 11 de 2020, de http://saocom.invap.com.ar/

Lillesand, M., \& Kiefer, W. (1994). Remote sensing and imageinterpretation. New York.

López Vázquez, V. H., \& Plata Rocha, W. (2009). Análisis de los cambios de cobertura de suelo derivados de la expansión urbana de la Zona Metropolitana de la Ciudad de México, 1990-2000. Investigaciones Geográficas(68), 85-101. Recuperado el 10 de 01 de 2020, de https://www.academia.edu/3497887/An\%C3\%A1lisis_de_los_cambios_de_ cobertura_de_suelo_derivados_de_la_expansi\%C3\%B3n_urbana_de_la_Z ona_Metropolitana_de_la_Ciudad_de_M\%C3\%A9xico_1990-2000 
Martínez Vega, J. J. (1996). Una revisión sobre las imágenes espaciales como fuentes cartográficas. Revista de teledetección: Revista de la Asociación Española de Teledetección, (6), 5.

Mateo, R., Sendra, J., \& Rocha, W. (2008). Análisis de posibles errores en la base de datos Corine Land Cover (1990-2000) en la Comunidad de Madrid. ESTUDIOS GEOGRÁFICOS, 69(264), 81-104.

Ministerio de Agricultura y Desarrollo Rural. (2012). Estudio de los conflictos de uso del territorio Colombiano. Recuperado el 11 de 03 de 2020, de https://repository.agrosavia.co/bitstream/handle/20.500.12324/12723/80286 _26460.pdf?sequence=1\&isAllowed=y

NASA. (2011). Landsat 7 Science Data Users Handbook Landsat Project Science Office at NASA's Goddard Space Flight Center in Greenbelt. Obtenido de http://landsathandbook.gsfc.nasa.gov/pdfs/Landsat7_Handbook.pdf

NASA. (2019). National Aeronautics and Space Administration. Recuperado el 21 de 03 de 2020, de Landsat Science-Landsat 4: https://landsat.gsfc.nasa.gov/landsat-4/

NASA. (21 de 03 de 2020). The Thematic Mapper. Obtenido de Landsat Science: https://landsat.gsfc.nasa.gov/the-thematic-mapper/

Niclós Corts, R., Estrela Navarro, M. J., Valiente Pardo, J. A., \& Barberá Bisbal, M. J. (2010). Clasificación periódica de coberturas terrestres a escala regional con imágenes MODIS. Geofocus -Revista Internacional de Ciencia y Técnologia de la Información Geográfica(10), 1-17.

Pontius, R. G., JShusas, J. E., \& McEachern , M. (2004). Detecting important categorical land changes while accounting for persistence. Agriculture, Ecosystems and Environment, 101, 251 - 268.

Reuter, A. F. (2002). Carpeta de Trabajos prácticos Teledetección Forestal, Practica 11: Transformación de la Imagen - Clasficaciones supervisadas y No supervisadas. Recuperado el 15 de 08 de 2019, de Facultad de Ciencias Forestales UNSE: https://fcf.unse.edu.ar/archivos/lpr/pdf/p11.PDF 
Riaño, O. (2002). Consideraciones y métodos para la detección de cambios empleando imágenes de satélite en el municipio de Paipa. Colombia forestal, 7(15), 41-62.

Richards, J. A., \& Jia, X. (2006). Remote Sensing Digital Imagen Analysis. New York, Berlin: Springer Verlag.

Salas Castillo, E. (06 de 06 de 2010). Análisis del cambio en la cobertura arbórea de la subcuenca del río el Tunal (1990-2008). Tesis de Maestría . Victoria de Durango, Mexico.

Sancho Comins, J., Bosque Sendra, J., \& Moreno Sanz, F. (1993). La Dinámica del paisaje: Aplicaciones de un SIG ráster al ejemplo de Arganda del Rey en las Vegas de Madrid. Madrid: $2^{\circ}$ época año.

Suárez-Parra, K., Cély-Reyes, G., \& Forero-Ulloa, F. (2016). Validación de la metodología Corine Land Cover (CLC) para determinación espacio-temporal de coberturas: caso microcuenca de la quebrada Mecha (Cómbita, Boyacá). Biota Colombiana, 17(1), 1-15.

USGS a. (2018). United States Geological Survey, Landsat 4. Recuperado el 21 de 03 de 2020, de Landsat Missions: https://www.usgs.gov/landresources/nli/landsat/landsat-4?qtscience_support_page_related_con=0\#qtscience_support_page_related_con

USGS a. (2019). United States Geological Survey, Landsat 7 Data Users Handbook. Recuperado el 10 de 11 de 2020, de https://prd-wret.s3.us-west2.amazonaws.com/assets/palladium/production/atoms/files/LSDS1927_L7_Data_Users_Handbook-v2.pdf

USGS b. (2018). United States Geological Survey, Sentinel-2. Recuperado el 21 de 03 de 2020, de USGS EROS Archive: https://www.usgs.gov/centers/eros/science/usgs-eros-archive-sentinel-2?qtscience_center_objects=0\#qt-science_center_objects

USGS b. (10 de 12 de 2019). United States Geological Survey, Using the USGS Landsat Level-1 Data Product. Recuperado el 11 de 11 de 2020, de Landsat 
Missions: https://www.usgs.gov/land-resources/nli/landsat/using-usgslandsat-level-1-data-product

Velasco, A. C., García, C. A. V., Morales, F. A. R., Castelblanco, S. F. C., \& Fuentes, H. A. (2015). Aplicaciones y retos del sensado remoto hiperespectral en la geología colombiana. Facultad de Ingeniería, 17-29. 
8. ANEXOS 


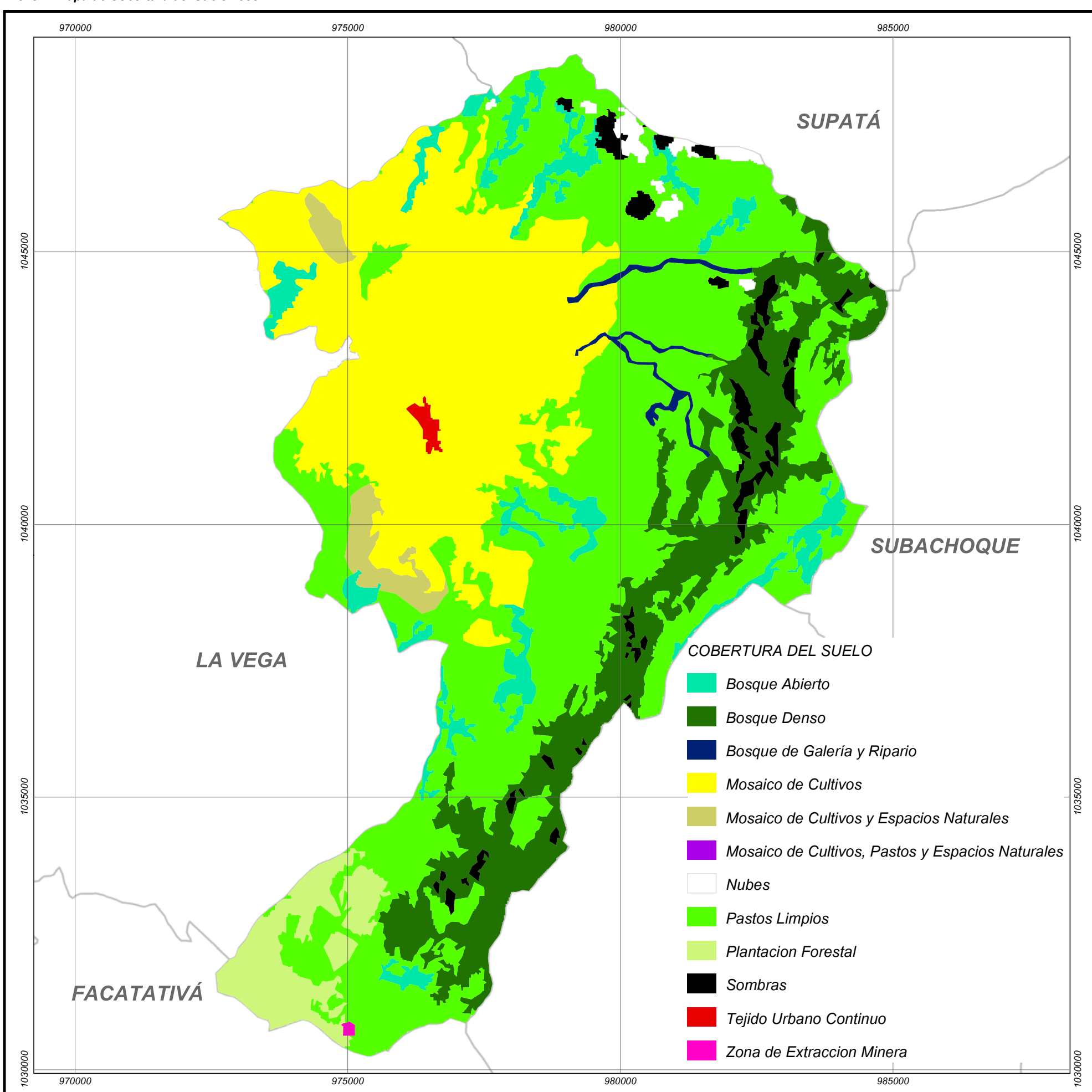

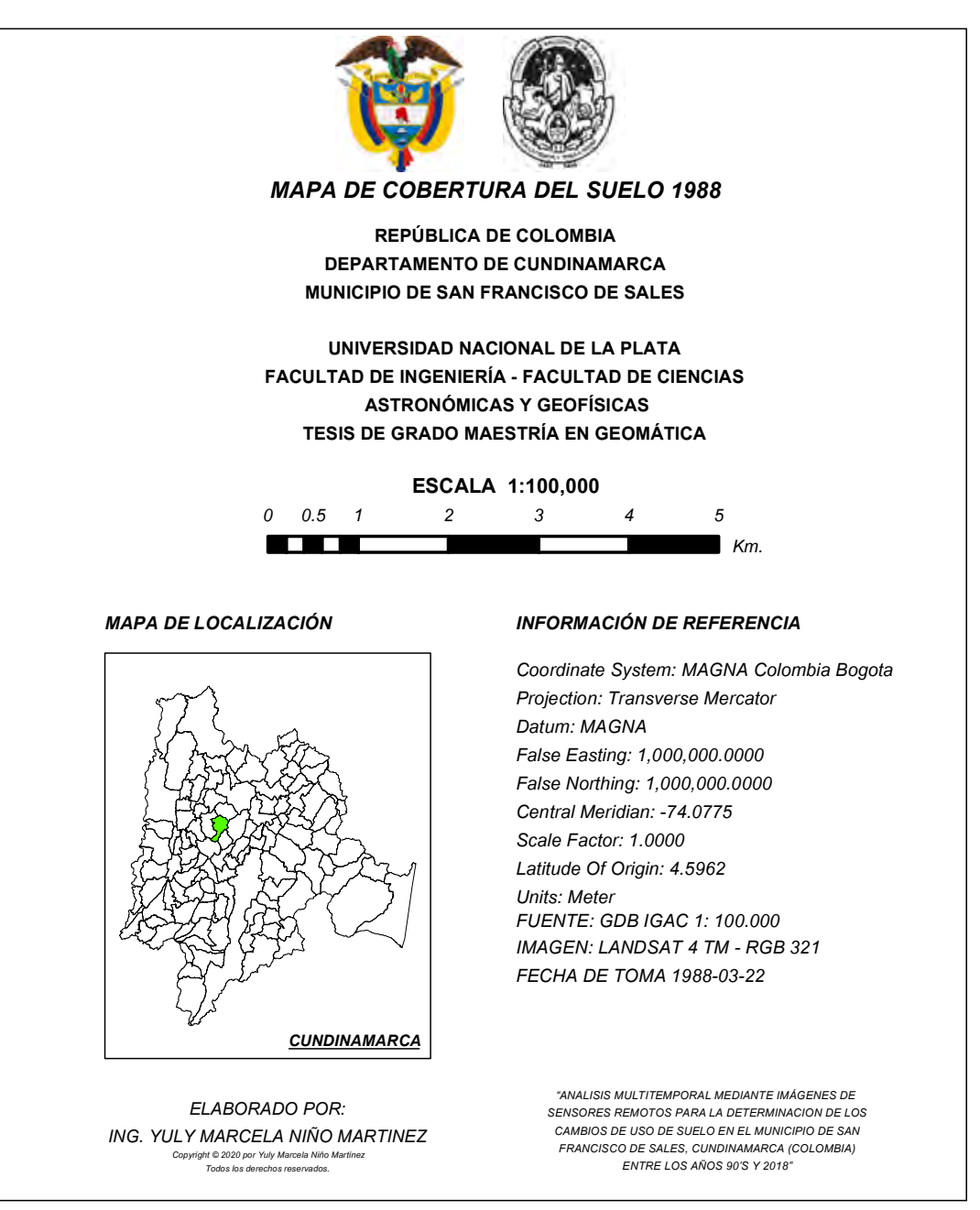

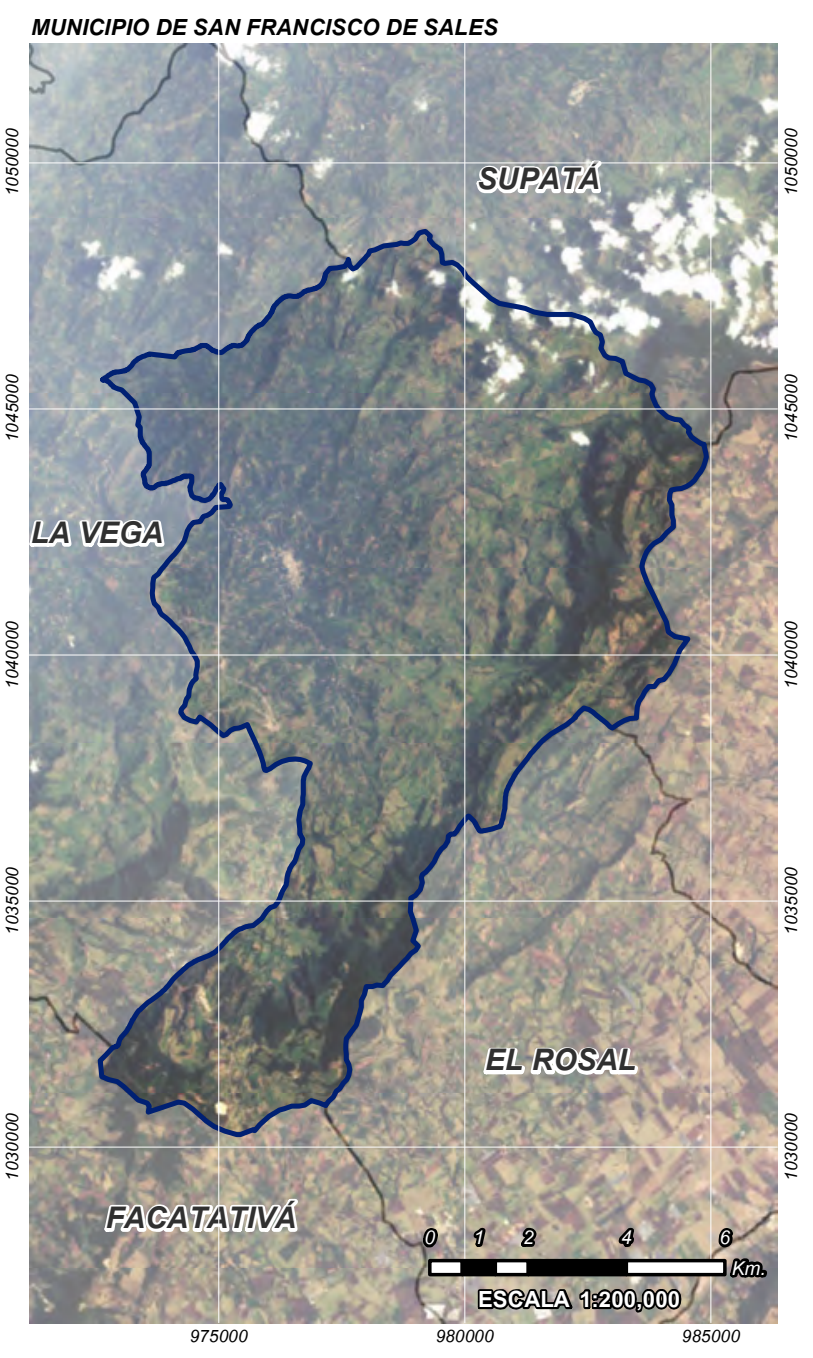




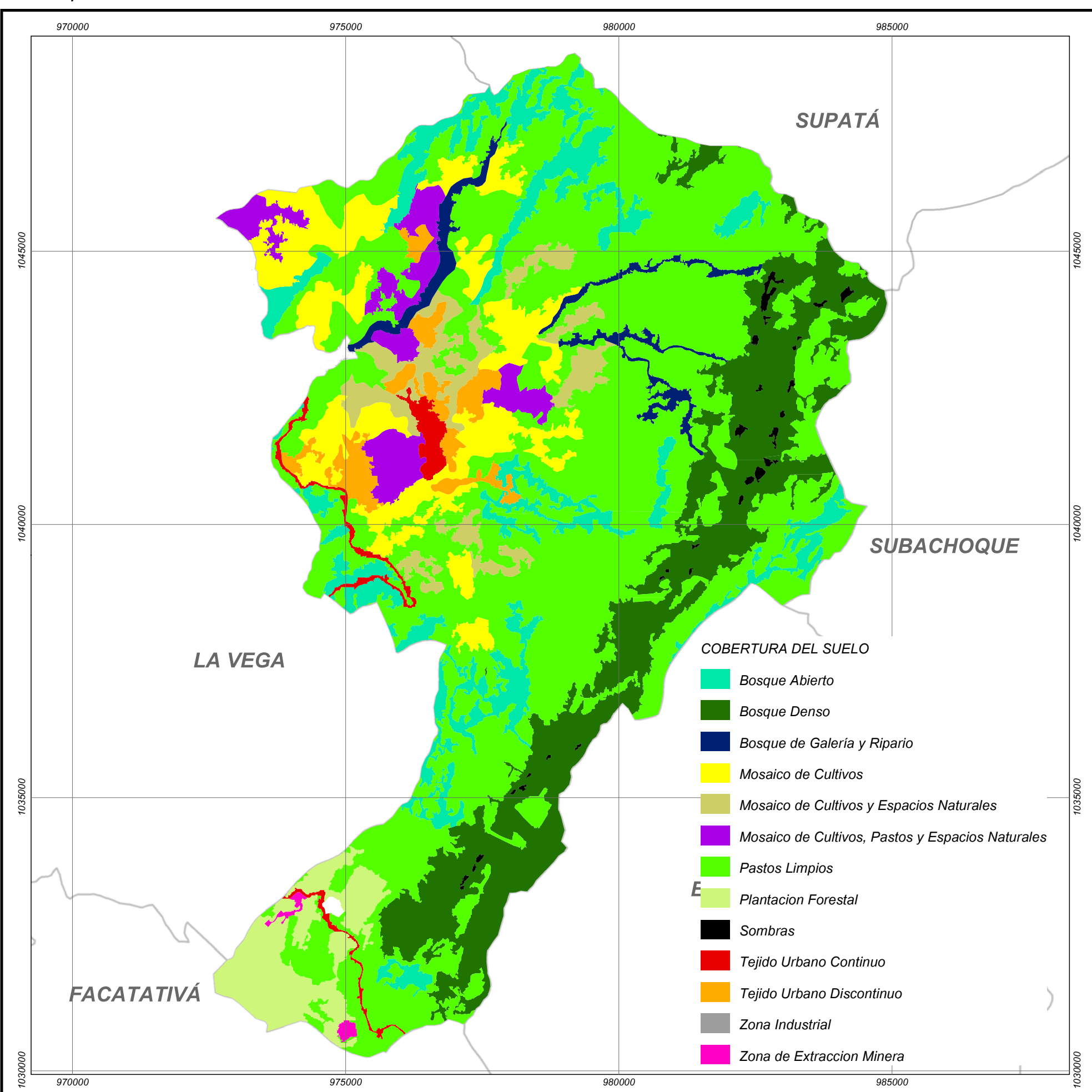

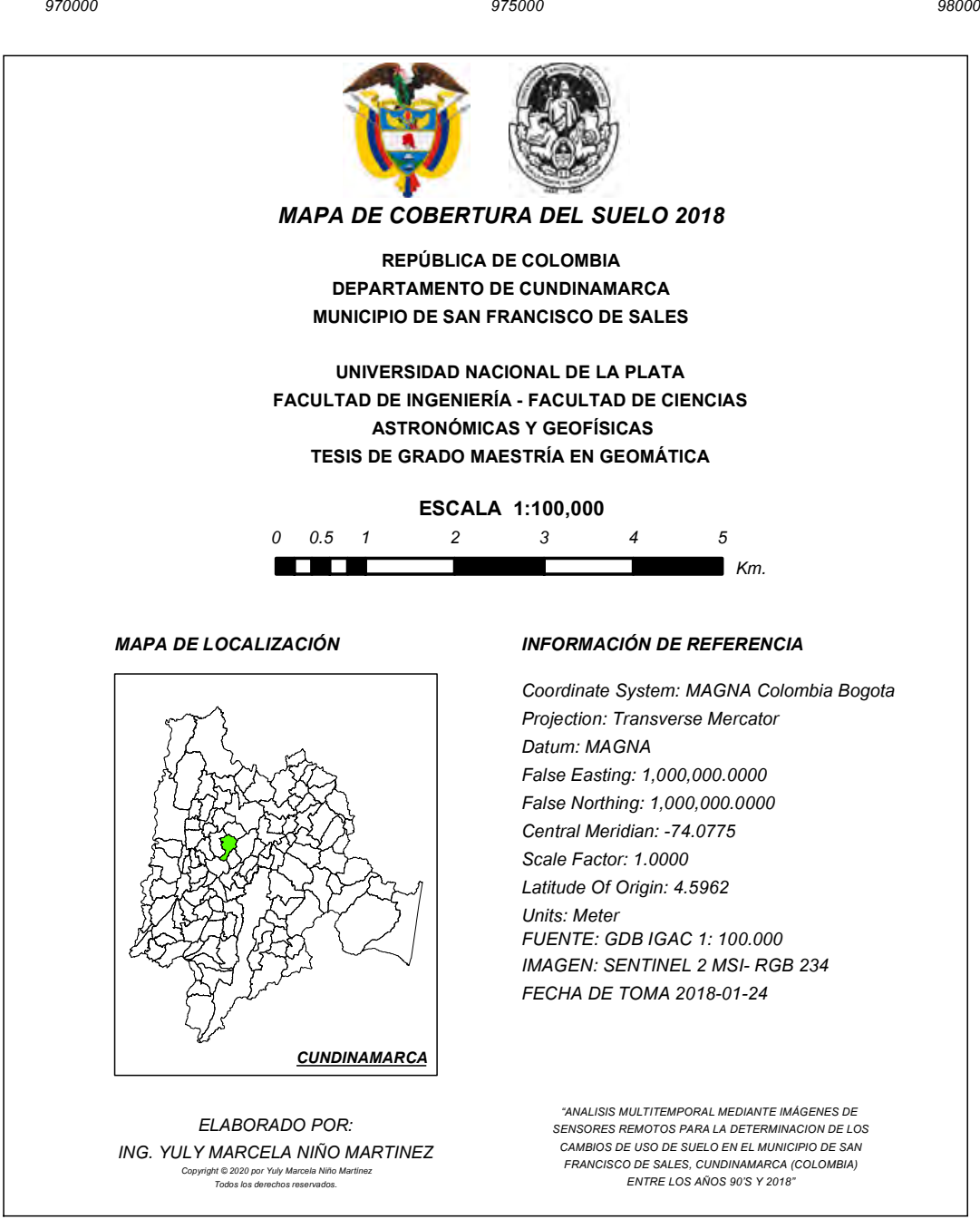

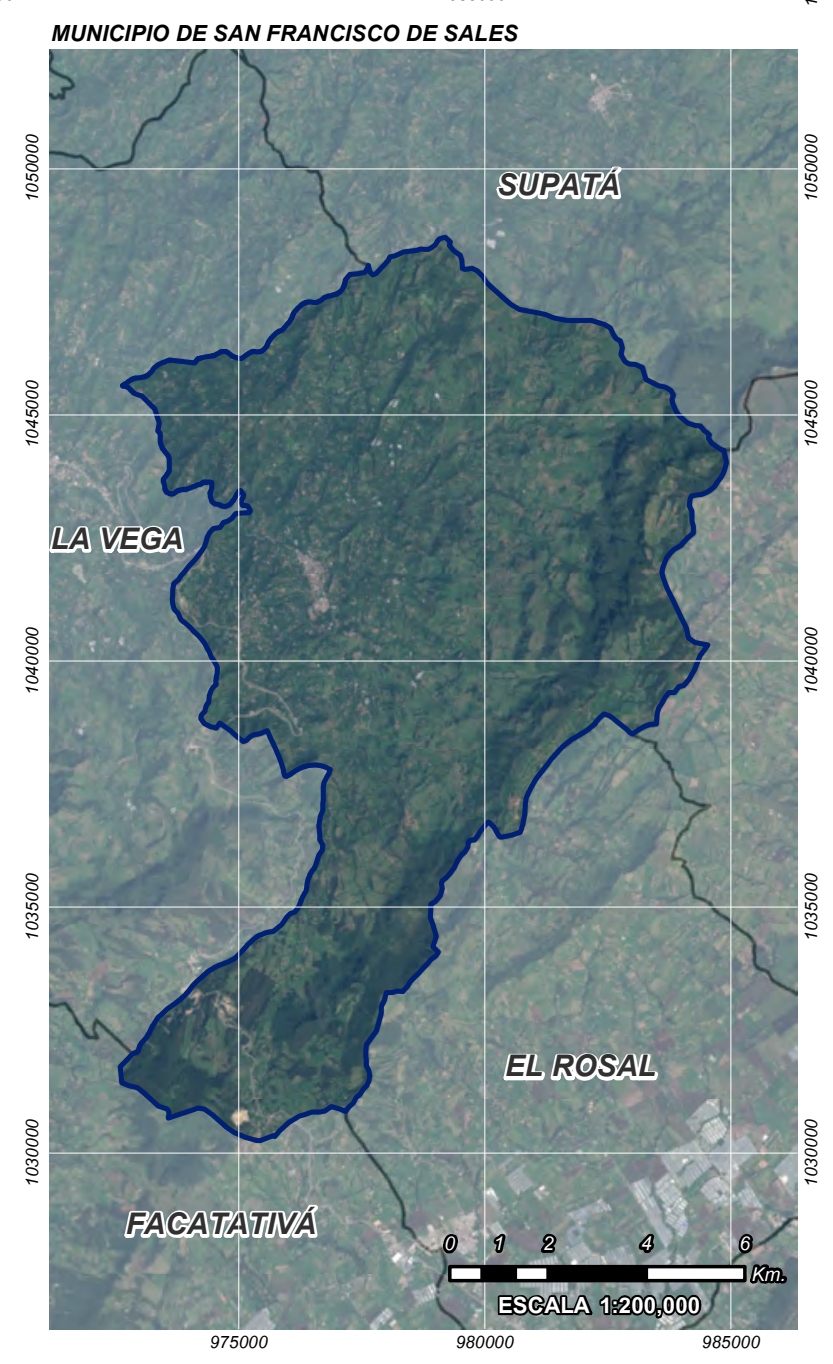




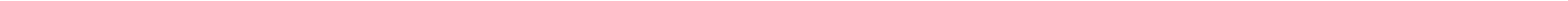




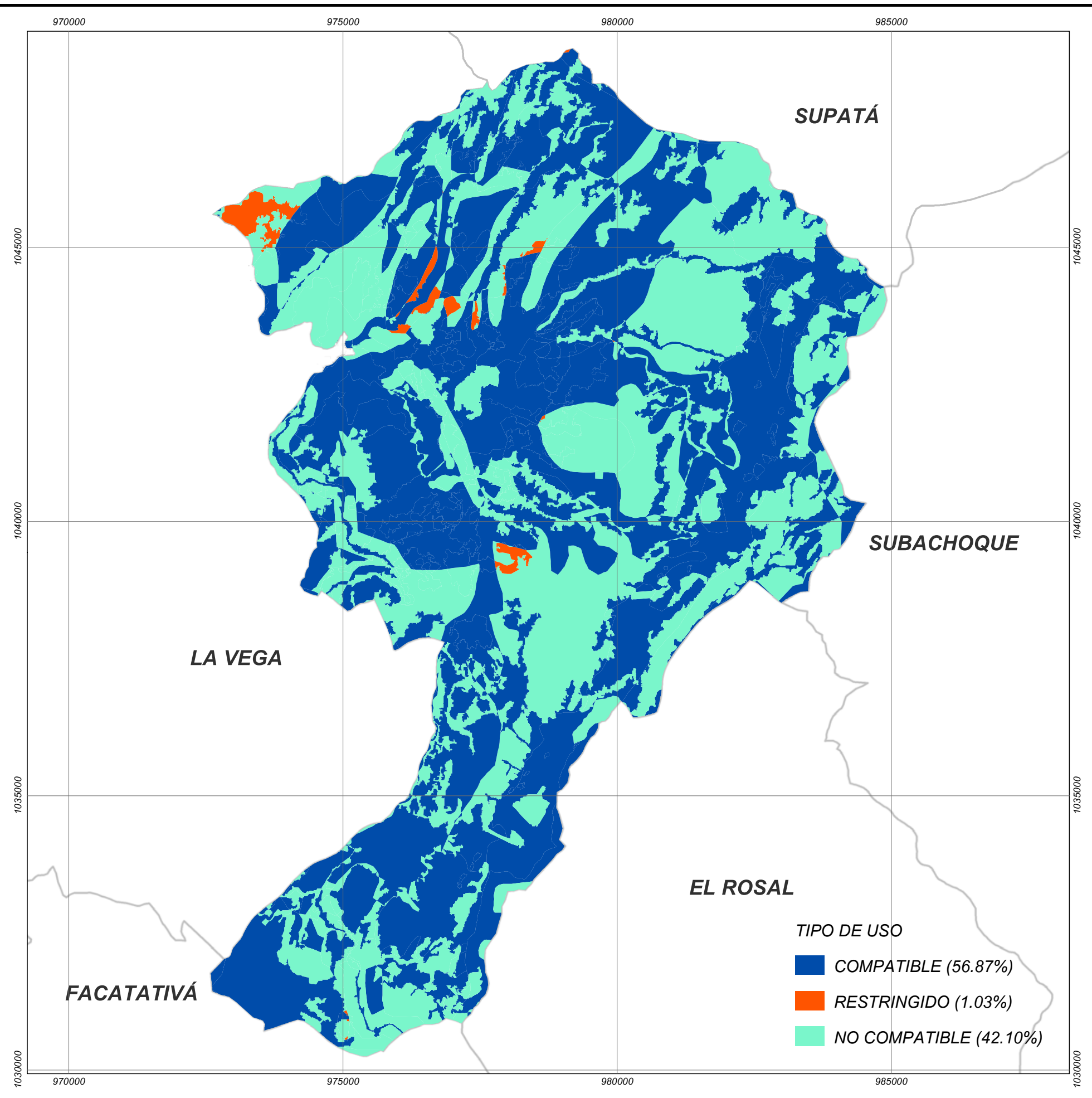

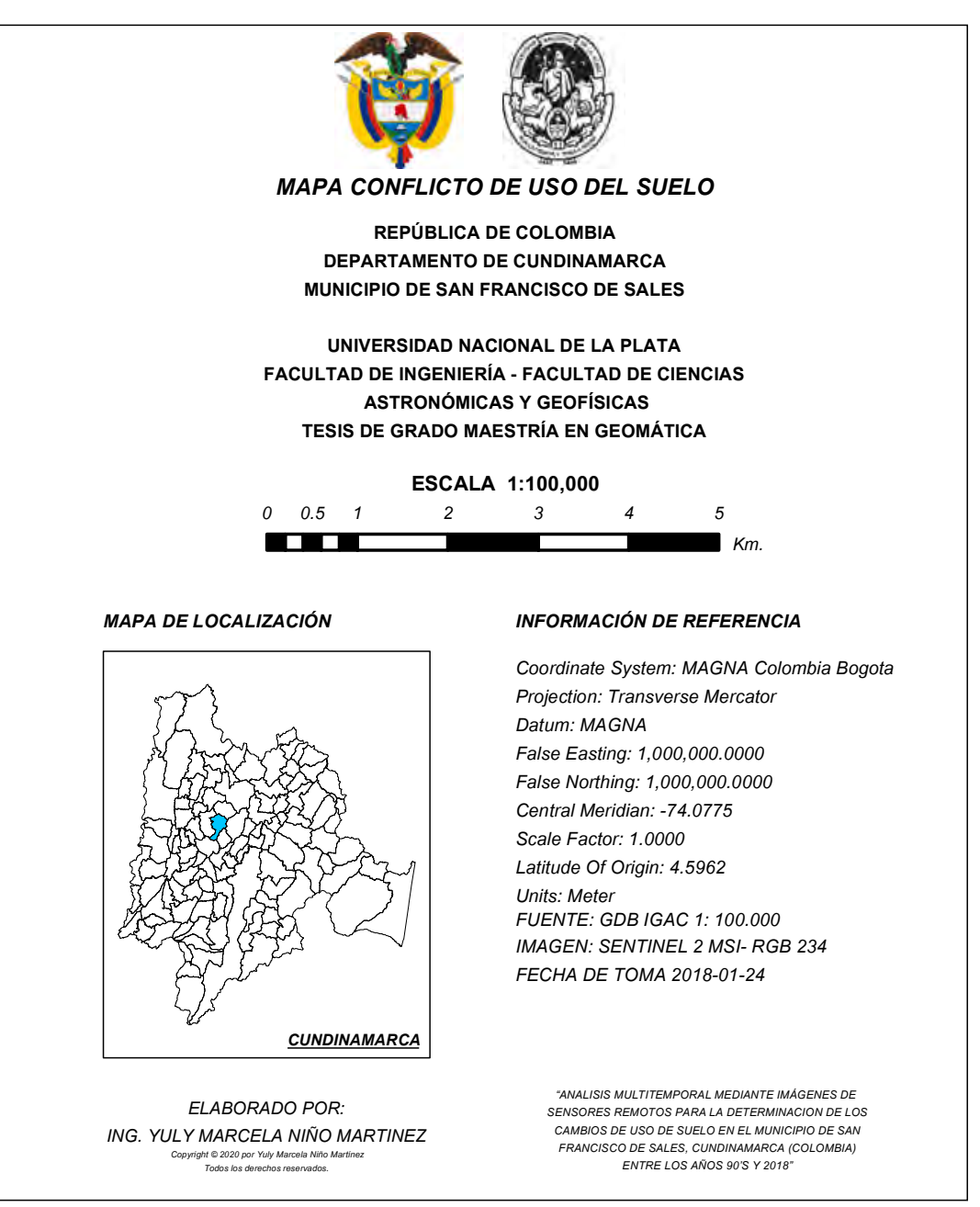

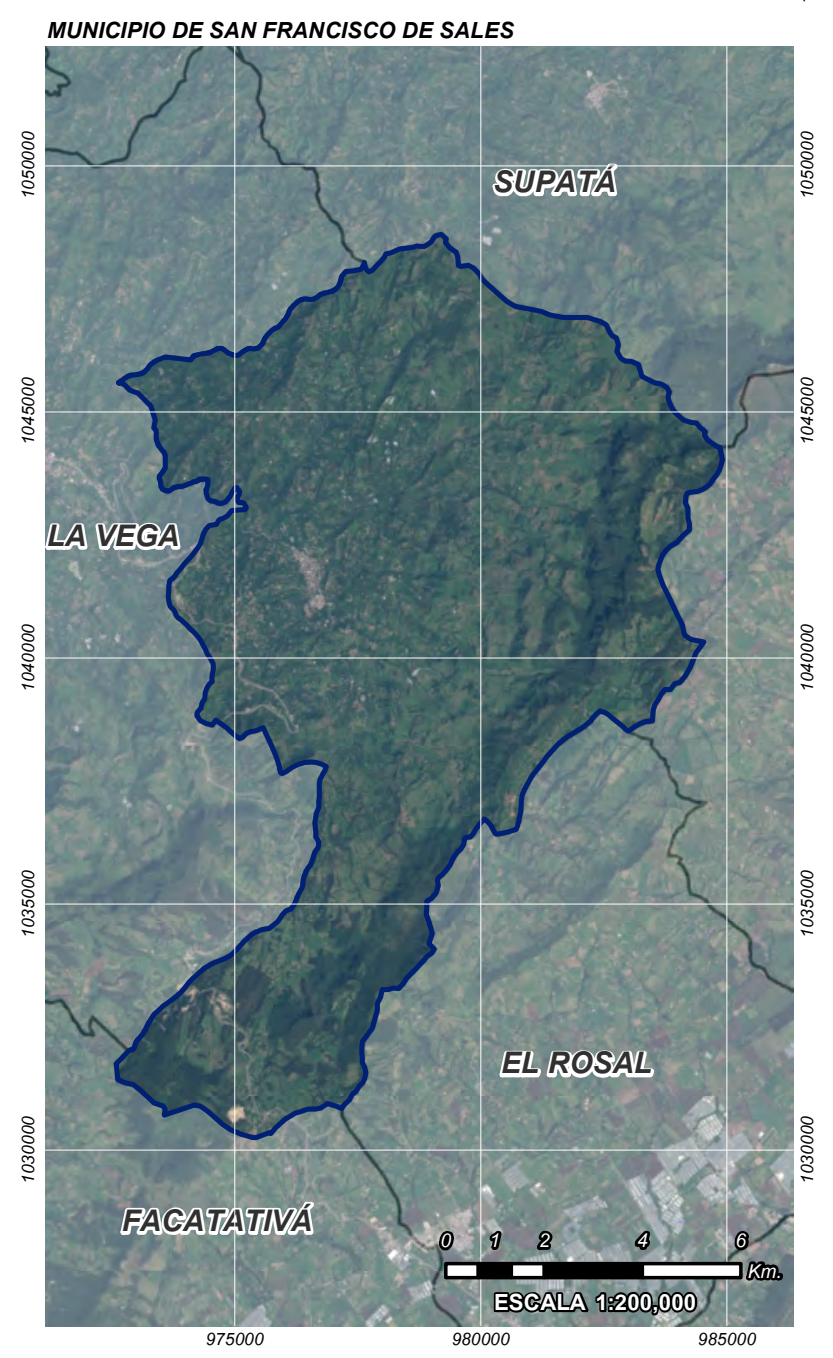

